Raquel

Ricardo

Sardá

Roncero

Sáncher

Palomar

Comportamientos artísticos en la era de los nuevos medios

Prólogo de Rafael Gómez Alonso

Cuadernos Artesanos de Comunicación / 87

ULL

Universidad

de La Laguna

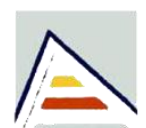

Universitat d'Alacant Universidad de Alicante

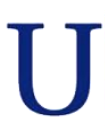

UNIVERSIDADE

DE SANTIAGO

DE COMPOSTELA

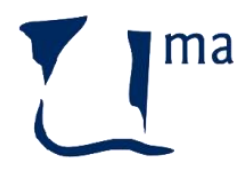

UNIVERSIDAD

DE MÁLAGA

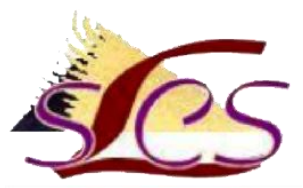

Sociedad Latina de

Comunicación Social 
Cuadernos Artesanos de Comunicación \# 87 - Comité Científico

Presidencia: José Luis Piñuel Raigada (UCM)

Secretaría: Concha Mateos (URJC)

- Bernardo Díaz Nosty (Universidad de Málaga, UMA)

- Carlos Elías (Universidad Carlos III de Madrid, UC3M)

- Javier Marzal (Universidad Jaume I, UJI)

- José Luis González Esteban (Universitas Miguel hernáncez de Elche, $\mathrm{UMH})$

- José Luis Terrón (Universidad Autónoma de Barcelona, UAB)

- José Miguel Túñez (Universidad de Santiago, USC)

- Juan José Igartua (Universidad de Salamanca, USAL)

- Marisa Humanes (Universidad Rey Juan Carlos, URJC)

- Miguel Vicente (Universidad de Valladolid, UVA)

- Miquel Rodrigo Alsina (Universidad Pompeu Fabra, UPF)

- Núria Almiron (Universidad Pompeu Fabra, UPF)

- Ramón Reig (Universidad de Sevilla, US)

- Ramón Zallo (Universidad del País Vasco, UPV-EHU)

- Victoria Tur (Universidad de Alicante, UA)

* Queda expresamente autorizada la reproducción total o parcial de los textos publicados en este libro, en cualquier formato o soporte imaginables, salvo por explícita voluntad en contra del autor o autora o en caso de ediciones con ánimo de lucro. Las publicaciones donde se incluyan textos de esta publicación serán ediciones no comerciales y han de estar igualmente acogidas a Creative Commons. Harán constar esta licencia y el carácter no venal de la publicación.

* La responsabilidad de cada texto es de su autor o autora. 
Raquel Sardá Sánchez y Ricardo Roncero Palomar

Prólogo de Rafael Gómez Alonso

\section{Comportamientos artísticos en la era de los nuevos medios}

Cuadernos Artesanos de Comunicación / 87

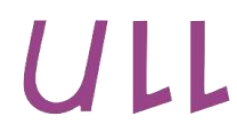

Universidad de La Laguna

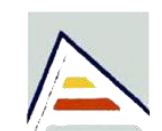

Universitat d'Alacant Universidad de Alicante
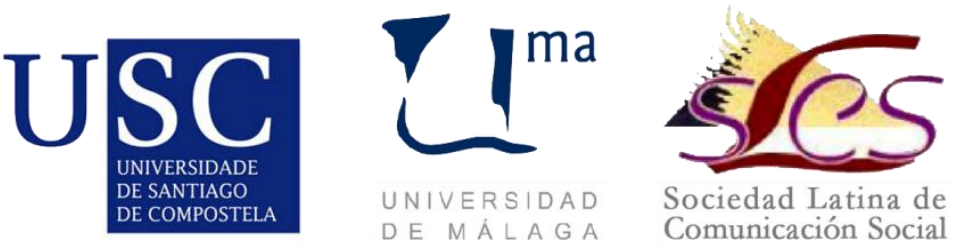
CAC $87^{\circ}$ - Comportamientos artísticos en la era de los nuevos medios

Raquel Sardá, Ricardo Roncero, Rafael Gómez

Precio social: 6,40€ | Precio en librería. 8,35€ |

Editores: Javier Herrero y Alberto Ardèvol

Diseño: F. Drago

Ilustración de portada: Ilustración de portada: Fragmento del cuadro Arboles y viento, de Juan Davó (sin fecha).

Imprime y distribuye: F. Drago. Andocopias S. L.

c/ La Hornera, 41. La Laguna. Tenerife.

Teléfono: 922250554 | fotocopiasdrago@,telefonica.net

Edita: Sociedad Latina de Comunicación Social - edición no venal

- La Laguna (Tenerife), 2015 - Creative Commons

(http://www.revistalatinacs.org/09/Sociedad/estatutos.html)

Catálogo http://www. cuadernosartesanos.html

Protocolo de envío de manuscritos con destino a C.A.C.:

http://www.cuadernosartesanos/protocolo.html

Descargar $p d f$.

http://www.cuadernosartesanos.org/\#87

ISBN - 13: 978-84-16458-19-6.

DL: TF-521-2015

DOI: $\underline{10.4185 / \mathrm{cac} 87}$ 


\title{
Comportamientos artísticos en la era de los nuevos medios
}

\begin{abstract}
La nueva realidad del artista en un ámbito de narrativas y propuestas de arte expendido, provoca la necesidad de analizar diversas creaciones y proyectos que nacen y se desarrollan en este modelo de creación, en la era de los nuevos medios.

En esta publicación de Cuadernos Artesanos se nos da a conocer algunas propuestas artísticas, modelos expositivos, experimentación y crítica en el marco de la innovación tecnológica.
\end{abstract}

\section{Keywords}

Arte, tecnología, multimedia, innovación, audiovisual.

\section{Forma de citar este libro}

Autor capítulo (2015): “Título del capítulo", en Comportamientos artísticos en la era de los nuevos medios, Raquel Sardá Sánchez, Ricardo Roncero Palomar, Rafael Gómez Alonso (Coords.). Cuadernos Artesanos de Comunicación, 87. La Laguna (Tenerife): Latina. 


\section{Índice}

Prólogo. Un cruce de caminos artístico

Rafael Gómez Alonso ……………………………………………………... 7

1. Nuevas temporalidades. El giro temporal y la expansión de las artes.

Rosa Jiménez Morales

2. Arte Corporal, Fotografía y Televisión.

Celia Balbina Fernández Consuegra

3. Exhibición actual de las prácticas artísticas en vídeo.

Francisco José Gómez Díaz.

4. El vídeo musical en el entorno de exhibición de las prácticas artísticas.

Ricardo Roncero Palomar, Raquel Sardá Sánchez

5. La colección "Catálogos virtuales de exposiciones" de la Facultad de Arquitectura y Urbanismo de la Universidad de Cuenca José Luis Crespo Fajardo

6. Sigue el Camino de Baldosas Amarillas. El tránsito indagador para los estudiantes de Bellas Artes a través del recurso metodológico Testindagación.

Laura de Miguel Álvarez

Autores. 


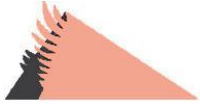 \\ Prólogo \\ Un cruce de caminos artístico
}

\author{
Rafael Gómez Alonso, Profesor Titular de Comunicación \\ Audiovisual de la Universidad Rey Juan Carlos
}

T OS procesos artísticos en el siglo XXI suponen un reto continuo a la creatividad y al impacto que ocasionan en la esfera pública y social. La representación de los nuevos medios visuales se encuentra en una encrucijada en la que los dispositivos, la reprogramación de espacios y el uso de plataformas y redes tecnológicas promueven narrativas expendidas. Todo ello ha configurado un nuevo territorio en el ámbito de aplicación de las tecnologías de la información y comunicación.

Continuamente aparecen nuevas instalaciones en las que se otorga una importancia decisiva a las sinergias producidas entre emisores (productores, realizadores y distribuidores) y receptores (público usuario y "prosumidor"). Las exhibiciones artísticas suponen diferentes formas de entender la representación audiovisual y de buscar y combinar distintas variables de campos artísticos, a veces distantes, que confluyen en la creación de una nueva estética. En este sentido, se están produciendo cambios en los modos de recepción y en la atracción hacia espectáculos que, por su condición de hibridación de medios, resultan muy atractivos y suponen una evolución tanto en los modos ver cómo en los de creación de contenidos y en la descripción o atribución de los mismos. 
A partir de estas premisas, se establecen diversas líneas de investigación en las que se muestran y entrecruzan formas atractivas de experimentar la creatividad artística que incorpora el uso de nuevas tecnologías comunicativas. Los medios tecnológicos, dentro de los circuitos artísticos, permiten explorar nuevos discursos que afectan a las formas de creación y comunicación, repensar los principios estéticos (afectividades) y las formas de relación social como plataformas que interactúan con instituciones políticas, culturales y espectaculares.

La investigación en nuevos medios permite estudiar la interacción entre los procesos de comunicación social y las manifestaciones artísticas que utilizan herramientas tecnológicas como la videocreación, la expansión de medios a otras esferas y espacios (como la fotografía y el cine en los museos), realidad aumentada, holografía y otros recursos de realidad virtual, las integraciones de los dispositivos móviles y sus apps respecto a las sinergias y procesos de experimentación y jugabilidad entre datos y obras, la posproducción y reprogramación de colecciones para ofrecer nuevas lecturas y significados desde perspectivas contemporáneas hacia épocas pasadas (estudios sobre heterecronía entre discursos y obras del pasado y el presente), la hibridación e intermedialidad en espacios expositivos, las cualidades de los registros y soportes multimedia, narrativas amplificadas e hipermedia, la implicación de las redes sociales y plataformas de internet en el entramado de las nuevas producciones artísticas, o la performatividad y convergencia entre las artes plásticas y escénicas, entre otros muchas de las cualidades que ofrece el amplio espectro de las manifestaciones artísticas contemporáneas.

Desde estas perspectivas, la presente publicación trata de ofrecer una cartografía de algunas implicaciones que ofrecen las nuevas tecnologías en las artes plásticas, escénicas y audiovisuales. A su vez, a través de diferentes investigaciones se plantea reflexionar y emprender continuos debates sobre el papel que juegan los medios de comunicación como instancias colaborativas en el proceso de la creación, información, accesibilidad y recepción de las obras.

El primer capítulo supone una inmersión en el debate conceptual sobre la dimensión temporal del arte. La expansión de los medios 
artísticos y audiovisuales hacia otras fronteras "intermediales" permite estudiar qué papel ofrecen las obras de arte bajo una nueva perspectiva de aplicación a la recepción estética. El concepto de obra artística ha pasado a determinar diferentes formas de entender el arte, cumpliendo una misión de objeto, de discurso o de artefacto. Los procesos y proyectos de exploración en la aplicación de las técnicas y tecnologías ha sometido el arte a nuevas vías de indagación sobre cómo articular la propia historia de la cultura, sus formas de hacer, los modos de ver y la configuración de nuevos criterios para comprender diferentes etapas de la posmodernidad ¿Se puede abordar el arte del siglo XXI de la misma manera que en el período donde comenzaron a extenderse las vanguardias a mediados del siglo pasado, o cuando empezaron a surgir nuevos debates rupturistas y conceptuales sobre el régimen de la mirada en el último tercio del siglo XX? ¿Cómo se experimenta la temporalidad de la obra artística y de su recepción con el uso de las nuevas tecnologías? Todo ello ha dado lugar a implantar una nueva línea de investigación amparada en los estudios visuales en los que la obra artística pasa a ser un objeto de reflexión interceptada por los usos y discursos que aporta nuevos datos a la reflexión y debate en la teoría del arte y la estética, según la relación con sus principios de exhibición, distribución, difusión, ampliación o coparticipación con otras obras y discursos. Se genera de esta manera una nueva concepción para entender cómo se constituyen los comportamientos artísticos contemporáneos. En este sentido, algunos teóricos, como el caso de Keith Moxey (2015), utilizan como base dialéctica de sus investigaciones la articulación sobre las formas de posicionarse frente a una determinada obra (objeto o artefacto denotado estéticamente) ofreciendo un nuevo sentido a la historia del arte, a la actitud del receptor, del autor y de la obra en sí misma para establecer un nuevo régimen de significados y sentidos de la cultura artística y audiovisual contemporánea.

El siguiente capítulo permite ahondar en la relación del arte corporal con la fotografía y videocreación. De este modo, se recapacita sobre la disposición que juega el Arte de Acción o Performance Art como proceso efímero y sus formas de registro audiovisual. El papel de la recepción, el espacio de intervención y el uso de las tecnologías en las performances configuran la propia historia y evolución de lo que ha 
supuesto investigar este modelo de actitudes emergentes y los planteamientos que ofrece la representación visual como simulacro y juego de interpelación al espectador. Dicha indagación permite, a su vez, reflexionar sobre la dimensión performativa del cuerpo como representación audivisual y establecer conexiones sobre la concepción de lo que Michael Fried (2004) ha venido a denominar como teatralidad, más allá de las fronteras del arte objetual, o dialogismo, tal como propone Julia Kristeva (1981) en las esferas que interpela a la dimensión corporal como acción textual.

El tercer capítulo se inscribe en las condiciones de las prácticas artísticas en video y sus problemas de difusión. En este terreno, la investigación expone las cualidades de representación más allá de lo que es en sí misma la obra de arte enmarcada en la videocreación para extrapolarla al terreno de lo que suponen las tecnologías audiovisuales en los proyectos artísticos, así como sus funciones dentro de los espacios museísticos y su difusión a través de las redes sociales y sus plataformas de exhibición. Las ideas que circulan en el texto permiten establecer nuevas y futuras investigaciones que se engloban dentro de las teorías enmarcadas en lo que se ha venido a denominar como "campo expandido", tal como propusiera Rosalind Krauss (1985) cuando desarrolló dicha hipótesis para reflexionar sobre el papel que desempeñaba el hecho escultórico más allá de las fronteras de la propia obra, o de la dimensión creativa que ofrecen los nuevos centros culturales y expositivos que manifiestan un reto a la concepción clásica del denominado cubo blanco y a las formas de implicación espacial, tal como subrayara Brian O’Doherty (2011).

El cuarto capítulo marca un recorrido sobre algunas de las exhibiciones de mayor calado que han presentado como objeto de estudio el videoclip. La reflexión sobre lo que supone el video musical y sus inmersiones en los espacios museísticos ha servido como propuesta de legitimación de su propio discurso amparado en terrenos del marketing y en su concepción de difusión televisiva para extrapolarlo hacia una noción más cercana al de la valoración artística propia de los procesos de videocreación. El videoclip se enmarca así en diferentes esferas o estratosferas complementarias y distantes entre sí en las vías de creación, exhibición, catalogación o distribución. ¿La 
circulación de la obra audiovisual cambia su propia noción de registro? La investigación permite estipular el lugar donde surge la concepción del hecho artístico: la obra (pieza individual en sí misma o su enclave en un proyecto colectivo para un grupo, tal como propone el articulo), la instalación de dicha pieza dentro de un espacio expositivo determinado o su posterior difusión por otros medios y canales de comunicación social. Desde el análisis de determinados casos de estudio, el texto se articula a través de experimentar dónde reside el valor del videoclip ¿En su proceso artístico y narrativo? ¿En su posterior exhibición dentro de un entorno determinado? ¿En su forma de distribución? Todo ello lleva a interrogarse, en un sentido más amplio, si realmente se ha pasado de preocuparse por ¿Qué es el arte? Frente a ¿Cuándo hay arte?, tal como expuso Nelson Goodman (1990).

El quinto capítulo presenta un análisis sobre la colección de "Catálogos virtuales de exposiciones" tomando como objeto de estudio la Facultad de Arquitectura y Urbanismo de la Universidad de Cuenca (Ecuador). En dicho artículo se aplican variables ligadas a la articulación de soportes y dispositivos de proyección visual y catalogación. Esta línea de investigación supone reflexionar sobre el papel que ocupa la documentación audiovisual y la catalogación de obras on line y su difusión en las redes sociales.

El sexto y último capítulo expone las cualidades y aportaciones de un recurso didáctico denominado Test-Indagación de aplicación para la investigación proyectiva en estudiantes de Bellas Artes. A través de esta herramienta se ofrece una nueva perspectiva para que los futuros creadores reflexionen sobre las posibilidades de la práctica artística, de sus métodos heurísticos y, especialmente, las implicaciones a la hora de explotar sus discursos. En este sentido, el texto se ampara en las experiencias de la docencia de narrativa audiovisual aplicada a las bellas artes, una materia que se predispone y articula no sólo en las vías de adaptación e incursión de las variables establecidas por dicha disciplina, confeccionada desde los preámbulos teóricos de la comunicación audiovisual, sino configurándose con nuevas posibilidades creativas de aplicación a otros terrenos artísticos. Desde esta focalización se amplían nuevas propuestas de aproximación a las 
obras, y diferentes formas de generar discursos artísticos y debates desde y sobre la concepción que implica el pensamiento artístico. En este sentido, y bajo estas propuestas, se proyecta una nueva dimensión en la articulación de la educación estética, tal como comenzó a vaticinar Mario Genneari (1997) con el uso y la aplicación de herramientas tecnológicas en un momento en que comenzaban a implantarse los nuevos medios a finales del siglo XX.

En definitiva, el libro propone un acercamiento a los comportamientos de los nuevos medios desde los procesos de creatividad, circulación de las obras, exhibición o catalogación, y con cierta inquietud hermenéutica para adentrarse en la intención crítica y experimental de crear un ámbito de estudio como estímulo para futuras investigaciones. Es, por tanto, un pequeño esbozo de la amplia cartografía que se configura a través del arte actual y sus experiencias con los dispositivos, tecnologías y herramientas (plataformas) en una era en la que se apuesta por nuevas formas de exhibición y de comunicación social (redes sociales, interacciones reales y simulacros interactivos), por la hibridación y resignificación del sentido de las obras, dando lugar a diferentes perspectivas de análisis que amplían el conocimiento interdisciplinar de las ciencias sociales y humanidades.

La articulación de dichos textos permite, por tanto, establecer diferentes focalizaciones sobre lo que suponen las nuevas esferas de la teoría artística actual y de la cultura audiovisual a través de experiencias particulares. De este modo, el objetivo final de esta conjunción de ensayos pretende establecer un entorno en el que enmarcar futuros debates de reflexión e investigación, más allá de lo que se entiende por la convergencia, disgregación y heterogeneidad de los comportamientos artísticos contemporáneos y su relación con los medios. 


\section{BIBLIOGRAFÍA}

Fried, M. (2004): Arte y Objetualidad. Madrid: Antonio Machado.

Gennari, M. (1997): La educación estética: arte y literatura. Barcelona: Paidós Ibérica.

Goodman, N. (1990): Maneras de hacer mundos. Madrid: Visor.

Krauss, R. (1985): "La escultura en el campo expandido" en La posmodernidad. Barcelona: Kairós.

Kristeva, J. (1981): Semiótica I. Madrid: Fundamentos.

Moxey, K. (2015): El tiempo de lo visual. La imagen en la historia. Barcelona: Sans Soleil.

O’Doherty, B. (2011): Dentro del cubo blanco. La ideología del espacio expositivo. Murcia: CENDEAC 



\section{Nuevas temporalidades. E1 giro temporal y la expansión de las artes}

Rosa Jiménez Morales, Profesora del Área de Cinematografía Escuela TAI, Centro adscrito a la Universidad Rey Juan Carlos

1. Introducción. Del ut pictura poesis a la expansión de las artes

T A expansión de las artes aparece estrechamente ligada a la $\perp$ posibilidad de comparación entre las diferentes disciplinas artísticas; comparación que, aunque es una técnica creativa habitual en nuestro tiempo, no siempre ha sido así. Si se conciben las artes como compartimentos estancos, el campo de la expansión se hace inimaginable.

En la Antigüedad el término arte no existía como tal. Ni el ars romano ni el téchne griego eran entendidos de la forma en la que lo entendemos en la actualidad, sino que hacían referencia a la capacidad del ser humano para realizar acciones.

A pesar de la ausencia del término arte, sí se habían realizado tímidas incursiones en la relación entre las artes. Las dos artes que más se habían comparado eran la pintura y la poesía, pues se consideraba que tenían la misma finalidad. Ambas servían para dar forma a una idea determinada del mundo, por lo tanto, utilizar una u otra sólo dependía del criterio del artista. No en vano se les llamó “artes 
hermanas"; hermandad que compartirían la escultura y la pintura más tarde y así "durante un periodo bastante dilatado dentro de la Historia del Arte europeo, que, aproximadamente, es el que transcurre del s. XIII al XVI y que marca la evolución estilística de las formas góticas a las propias del Renacimiento (dicen si Alonso de Berruguete estudió con Miguel Ángel), la Pintura y la Escultura forman un todo indiscernible" (Jardi, 1968: 28). Independientemente del soporte utilizado, el arte debía servir a la verdad. Es decir, primaba el grado de iconicidad y no la disciplina artística.

Aristóteles, por su parte, se valió de lo pictórico para analizar las características de la poesía, pero ya se observa en él algo que va a ser una constante: la jerarquía entre las diferentes artes, en este caso entre distintos géneros: "[...] en cierta medida el alma de la tragedia es el argumento [...] Pues ocurre algo semejante a lo que sucede en pintura: pues si alguien pintara un cuadro con los más bellos colores, pero mezclados de manera confusa, no agradaría tanto como si dibujara una figura sobre un lienzo blanco." (Aristóteles, 2004: 50).

Pero sin duda el paradigma de la relación entre las artes lo constituye el famoso ut pictura poesis de Horacio y que negaba la especificidad de las artes. "Como la pintura, así es la poesía: una te cautivará más cuanto más cerca estés de ella, y otra cuanto más lejos te encuentres; ésta requiere ser vista en la oscuridad, aquella otra a plena luz, pues no teme el examen penetrante del crítico; ésta gustó una sola vez, aquella, aun diez veces vista, seguirá gustando" (Horacio 1999: 95).

Esa relación entre las artes se va a olvidar por completo durante el Clasicismo. El debate sobre la hibridación de las artes y la problemática asociada a la misma se haría mucho más incisivo. Se proclamará la separación de las artes. Lessing escribe su "Laocoonte" basándose precisamente en ello. Si el "ut pictura" horaciano significaba el paradigma de la no especificidad de las artes, el "Laocoonte" de Lessing lo era de la radical separación entre ellas. Este ensayo se basa en la representación de las pasiones en el arte griego. Lessing va a comparar el fragmento de la Ilíada sobre el Laocoonte y el grupo escultórico del mismo nombre realizado por la 
escuela de Rodas. Laocoonte fue el sacerdote pítico de Troya que avisó sobre el peligro de aceptar la ofrenda que los aqueos les ofrecieron a los troyanos. Como ellos no escucharon su consejo, intentó quemar el caballo de madera pero en aquel momento dos serpientes gigantes salieron del mar atacándole a él y a sus hijos y se lo impidieron. Para Lessing el sufrimiento era representado de forma disímil en Homero y en el grupo escultórico. Mientras que en la escultura apenas se ahondaba en el sufrimiento de Laocoonte mediante la expresión de un leve gesto de súplica y de dolor contenido, la literatura focalizaba en mayor medida en el sufrimiento. Así, aunque ambas formas de arte se basaban en la representación mimética de la realidad, el acercamiento se producía de forma diferente, ya que la elección de un arte u otro provocaba diferentes representaciones de lo real. Afirma Lessing: "Si es cierto que la pintura, para imitar la realidad, se sirve de medios o signos completamente distintos de aquéllos de los que se sirve la poesía - a saber, aquélla, de figuras y colores distribuidos en el espacio, ésta, de sonidos articulados que van sucediéndose a lo largo del tiempo - ; si está fuera de toda duda que todo signo tiene necesariamente una relación sencilla y no distorsionada con aquello que significa, entonces signos yuxtapuestos no pueden expresar más que objetos yuxtapuestos, o partes yuxtapuestas de tales objetos, mientras que signos sucesivos no pueden expresar más que objetos sucesivos, o partes sucesivas de estos objetos Los objetos yuxtapuestos, o las partes yuxtapuestas de ellos, son lo que nosotros llamamos cuerpos. En consecuencia, los cuerpos, y sus propiedades visibles, constituyen el objeto propio de la pintura. Los objetos sucesivos, o sus partes sucesivas, se llaman, en general, acciones. En consecuencia, las acciones son el objeto propio de la poesía” (Lessing, 1977: 165).

La dialéctica de la Historia provocaría la llegada del Romanticismo; un periodo en el que la hibridación de las artes va a ser un leitmotiv tanto desde el punto de vista teórico como del práctico. De hecho, nuestra época bebe completamente de él. Proyectos como el Arte Total de Wagner (ejemplo máximo de hibridación) prepararon el terreno para que durante las vanguardias la experimentación fuera llevada a lo multidisciplinar. El dadaísmo, el movimiento Fluxus 
liderado por John Cage, la propuesta de un Teatro Total realizada por los miembros de la Bauhaus, etc no son más que ejemplos aislados de la disolución de la frontera entre las artes.

En los años 80 Rosalind Krauss le puso nombre a este fenómeno y proclamó la expansión en la escultura. Desde entonces la expansión en las artes -el transgénero- ha sido un hecho que se ha repetido fuertemente. En España obras como la de Guillermo Mora, Esther Mañas o Juan Ugalde juegan con los límites entre las artes creando híbridos polémicos y difícilmente etiquetables. Esta expansión en las artes, en el terreno que nos ocupa en este capítulo, se ha producido de la mano de lo que se ha denominado "el giro temporal en el arte" tanto en el contenido como en la forma de manifestar la expansión.

\section{La irrupción de las temporalidades múltiples}

La altermodernidad, ese periodo histórico que según Nicolas Bourriaud (2009) sucede a la posmodernidad, se ha caracterizado por la ruptura del tiempo teleológico occidental y una acusada concepción del presente como la temporalidad por excelencia de nuestros tiempos. Este hecho fue explicado por Michel Mafessoli en una entrevista a la revista $\tilde{N}$ donde afirmaba: "lo que está en gestación actualmente, la gran tendencia, está focalizada en el presente; la idea misma de futuro ya no moviliza las energías".

La temporalidad hasta que se produce la brecha había sido concebida de forma lineal. El Cristianismo y su reino de los fines impondrían una visión hacia el futuro que se acentuaría aún más durante la Ilustración cuando se concibe la idea de progreso como la tendencia natural en el ser humano; idea que no habría de ponerse en duda hasta la llegada de la II Guerra Mundial. De hecho, el Espíritu Absoluto hegeliano no es más que la reinterpretación de esa ideología teleológica en la que, con la ayuda del saber y la tecnología, se podía dominar la naturaleza y alcanzar ese reino de los fines en lo terrenal.

\footnotetext{
${ }^{1}$ Disponible para su consulta online: http://edant.revistaenie.clarin.com/notas/2009/09/26/ -02006102.htm
} 
El progreso se daría de bruces con el siglo XX, las dos guerras mundiales y, especialmente, las bombas atómicas sobre Hiroshima y Nagasaki. El dominio de la técnica no conducía hacia la perfección del ser humano ni éticamente ni socialmente, sino que lo llevó hacia la capacidad de autodestruirse. A ello se añadía que el anhelo de progreso eran inconmensurable mientras que los recursos naturales se han revelado limitados (de ahí que la idea de progreso se cambiara por la de desarrollo sostenible). Por lo tanto, el futuro dejó de ser una temporalidad anhelada para convertirse en algo atemorizador. La temporalidad lineal, como el resto de grandes verdades que nos había narrado la Modernidad (los grandes relatos, según Lyotard), se fragmentó en múltiples temporalidades.

Luis Racionero ha estudiado las diferencias en la concepción de la temporalidad en Occidente y en Oriente. Dice Racionero: "La mitología permite discernir en el subconsciente de orientales y de europeos dos ideas del tiempo radicalmente distintas: tiempo cíclico de Oriente y tiempo lineal de Occidente. Asia está regida por el signo del eterno retorno, de ahí su fatalismo -ese conformismo que irrita al occidental- y la inmensa paciencia de unas culturas que se cierran, autocomplacidas, sobre sí mismas. Europa es la tierra del tiempo lineal, del viaje y el progreso, de los pueblos irredentos cuya mitología habla de una caída original, un trabajo de liberación y transformación, al final de los tiempos" (2001: 36). El relato de superación occidental, presente en la mitología asociada a los héroes, puede percibirse incluso en la onomatopeya con la que se representa el paso del tiempo marcado por el reloj. Frank Kermode (1983) ha señalado cómo el tic-tac indica una concepción temporal en la que hay un principio y un final definidos y cómo el periodo de tiempo comprendido entre ambos sonidos parece producirse sólo en función de ellos.

Sin embargo, en los últimos años el tiempo cíclico de Oriente y el tiempo teleológico de Occidente se han aproximado hasta llegar a fundirse en muchas ocasiones. Las frases de autoayuda que pueblan nuestra época como "vive el presente", o el éxito del best seller "El poder del ahora" (Eckhart Tolle) son sólo algunos ejemplos de esa 
glorificación del instante por el instante y no como paso intermedio hacia el futuro.

En el ámbito del arte se ha rechazado la lógica temporal teleológica por considerarse propia de un pensamiento etnocéntrico. Las teorías sobre la nueva temporalidad se han multiplicado. Keith Moxey (2013) en su célebre artículo "Is Modernity Multiple?" hablaba sobre la apertura de la temporalidad occidental a nuevas concepciones migradas desde Asia. Christine Ross (2014), por su parte, estudia la temporalidad como una relación simbiótica entre el pasado, el presente y el futuro, mientras que Didi-Huberman (2005) ha hecho hincapié en la heterocronía de la imagen, es decir, en las diferentes temporalidades contenidas en la misma.

El rechazo de la linealidad temporal en la praxis artística ha significado en muchos casos un rechazo del capitalismo por cuanto esa temporalidad acumulativa ha sido considerada un síntoma de la aceleración del tiempo capitalista. La acumulación y la vivencia del futuro conducen a lo que Deleuze y Guattari denominaron como capitalismo esquizofrénico. En los tiempos hipermodernos, como afirma Lipovetsky (2006), la tendencia es a moverse hacia adelante, hacia una meta que, al ser invisible, sólo permite la huida, como si la sociedad se moviera en una road movie permanente. La aceleración, el saber acumulativo y el movimiento continuo son características fácilmente visibles del sistema capitalista.

Y así nos encontramos con obras que aceleran o dilatan el tiempo, lo fragmentan o directamente lo congelan creando anacronismos de la imagen. La introducción de las nuevas tecnologías en el arte ha propiciado una mayor experimentación con la temporalidad. Se podría decir que la tecnología en general fomenta ese presenteísmo del que hablaba Maffesolli en una sociedad que vive en el aquí y el ahora del "estar conectado".

A su vez y como consecuencia de ello, el régimen de historicidad ha sido cuestionado. La Historia y la historicidad, que no son más que una consecuencia de la narratividad teleológica, han sido revisitadas y 
puestas en entredicho. Desde la teorización del archivo en la obra de Aby Warburg (2010) hasta documentales como The Act of Killing (Joshua Oppenheimer, 2012) han reconstruido la Historia y la han reelaborado desde otro punto de vista y no desde la posición hegemónica de los vencedores. Como afirma Christine Ross: "la noción de régimen de historicidad es crucial para comprender el giro temporal [...]. Ha sido propuesto por el historiador francés François Hartog como un arma conceptual a tener en cuenta para las diferentes formas con las que las civilizaciones occidentales han ordenado y articulado la relación entre pasado, presente y futuro" (Ross, 2014: 13).

Vamos a analizar dos formas de aproximación a la construcción del sentido mediante la fragmentación a través de dos autores muy diferentes en su forma de concebir el arte; artistas ambos que pertenecen al terreno de la expansión en las artes: Douglas Gordon y Tony Oursler.

\section{E1 cine expandido}

Como hemos visto en el primer apartado, el fenómeno de expansión en las artes comienza en la Antigüedad con la comparación entre las distintas disciplinas. Sin embargo, la acuñación del término se producirá en los años 80 cuando la teórica Rosalind Krauss hable de expansión en las artes para referirse a obras que aparentemente no eran escultóricas, pero que los artistas etiquetaban como esculturas. Dice Rosalind Krauss: “[...] las categorías como la escultura y la pintura han sido amasadas, extendidas y retorcidas en una demostración extraordinaria de elasticidad, una exhibición de la manera en que un término cultural puede extenderse para incluir casi cualquier cosa" (2008: 60).

Ese giro temporal en el cine ha venido representado especialmente por el cine experimental y el cine expandido. El cine expandido, además de representar un cambio en la naturaleza de exhibición del cine y de la naturaleza de conservación del pasado (los museos son, por definición, conservadores, están destinados a salvaguardar el 
pasado), suele utilizar técnicas de ruptura temporal en la que los bucles, la fragmentación y la congelación del instante son una constante. La temporalidad, entendida como temporalidad narrativa de la imagen, al constituirse desde la fragmentación y la ruptura, deja la construcción del sentido al espectador.

Experimentos formalistas como ralentización de la imagen, el anacronismo de las imágenes o la utilización de la pantalla múltiple hacen que el presente se instale como tiempo por excelencia de los artistas de la contemporaneidad. Como afirma Amalia Martínez: "Pero la dimensión de la temporalidad irrumpe en las obras de arte contemporáneo por una tercera vía, la temática. Si el arte tradicional inscribía el pasado en la dimensión simbólica sustrayéndolo a la temporalidad, y las vanguardias eran anticipación del futuro, el arte de hoy sólo se compromete con el presente" (Martínez, 2000: 11).

Esa elasticidad se ha dado, como en el resto de artes, en el ámbito de lo cinematográfico y así ha nacido el cine expandido. Gene Youngblood publicaba en los años 70 su célebre "Expanded Cinema" a partir del término inventado por Stan Vanderbeek en 1966. Dicha publicación elevaba el vídeo a la categoría de arte y permitía la entrada en los museos de los filmes. Ese acercamiento permitió una doble transformación en el cinematógrafo. Por una parte, conectaba el cine y el arte contemporáneo. La historia del cine ha obviado casi por completo el cine experimental (más próximo al cine expandido en su concepción de lo cinematográfico). La historia del cine suele ser la historia de tres ramas: la documental con los Lumière, la fantasía y de ciencia ficción con Méliès y la narrativa con Griffith (de la que, evidentemente, la fantasía y la ciencia ficción formarían parte). Salvo para aquellos interesados en ello, el cine experimental queda lejos de ser reconocido como forma válida de lo cinematográfico. $\mathrm{Y}$, por otra parte, el acercamiento permitió forzar lo cinematográfico más allá de los límites en los que se había encasillado el cine.

Esta expansión es lo que Peter Greenaway defiende en su conferencia "New Possibilities: Cinema is Dead. Long Live Cinema". La expresión hace referencia al lema "el rey ha muerto, viva el rey", que 
se utilizaba en los periodos entre reinados para mantener el espíritu monárquico y evitar sublevaciones. Para el director estadounidense, no tiene sentido continuar realizando cine de la forma en la que se hace, es decir, de forma narrativa. El cine debía aproximarse al resto de las artes y abandonar una supuesta especificidad que es artificiosa y no intrínseca al medio.

Andrew V. Uroskie (2014: 35-6) señala el origen del cine expandido en la conexión entre tres elementos. Por una parte, las transformaciones en la exhibición tradicional en las salas provocado fundamentalmente por la piratería. Ello conlleva la disminución de público en las salas y relaja la presión de creación de una obra que funcione en taquilla. En segundo lugar, el acceso de las imágenes en movimiento a los museos. Hace ya años que los museos han abandonado su idea de obra estática para introducir videoarte, documentales y cine experimental. El cine expandido parece la evolución casi natural de dicho cambio. El tercer elemento se trataría de la intermedialidad en el teatro a través de la introducción de pantallas en las obras. Este hecho, como sucede con las categorías de lo nuevo, lleva realizándose desde hace años, casi desde la invención del cinematógrafo, pero es indudable que en la actualidad hay una proliferación de ello. Artistas como el canadiense Robert Lepage crean obras de teatro con elementos propios del cine (creación de títulos de crédito, utilización de pantallas para paliar la limitación del primer plano en el teatro, etc).

La re-espacialización del cine debido a la expansión ha venido acompañada de un cambio en las condiciones de recepción de la obra. En lugar de la recepción pasiva propia de la sala de cine, se fomenta una relación peripatética con la obra. El espectador camina, elige su propia perspectiva. La cámara pierde parte de su hegemonía en favor de la recepción.

Como hemos anticipado, una de las técnicas más habituales en el cine expandido es la de la dilatación del tiempo para desmontar la temporalidad propia de Occidente. Vamos a analizar una de las obras más célebres en ello: 24Hours Psycho. 


\section{4 horas de Psicosis es mucha psicosis}

De todas las obras surgidas del giro temporal en Occidente, quizá sea 24Hours Psycho la que mejor demuestre cómo un cambio en la temporalidad supone igualmente un cambio en la narratividad de una obra.

En la instalación ideada por Douglas Gordon en 1933, se proyectaba la película "Psicosis" a dos imágenes por segundo en lugar de los veinticuatro fotogramas por segundo estándar en el cine. Por lo tanto, el tiempo del filme era dilatado hasta alcanzar las veinticuatro horas de metraje, es decir, veinticuatro horas de Psicosis. Esa transformación en la temporalidad de la obra venía acompañada de una metamorfosis en el sentido. Para decirlo de forma llana: veinticuatro horas de Psicosis (la película) eran mucha psicosis (como enfermedad). La psicosis se manifiesta en episodios agudos aislados, por lo que su prolongación en el tiempo resulta artificial para el espectador y, por supuesto, su efecto se diluye.

El propio Hitchcock, el gran maestro del suspense, argumentaba en el célebre libro de entrevistas que le realizó Truffaut que la diferencia entre la sorpresa y el suspense estribaba en la duración de cada uno de ellos y en el conocimiento o no por parte del público de que iba a suceder un determinado acontecimiento (Truffaut 2001: 68-70). El suspense conlleva una temporalidad de mayor dilatación que la producida por la sorpresa que suele ser un golpe de efecto rápido y contundente. Esa diferenciación entre una y otra parece evidente. La diferencia se complica cuando el suspense se dilata durante horas. El Diccionario de la Real Academia Española define el suspense como la "expectación impaciente o ansiosa por el desarrollo de una acción o suceso, especialmente en una película cinematográfica, una obra teatral o un relato". La expectación, como toda espera, si se mantiene en el tiempo pierde su propia naturaleza. La expectación es siempre expectación de algo y la pausa continua, el avanzar demasiado lento de la trama, anula la propia trama. 
Steven Jacobs ha abordado la relación entre la imagen-tiempo de Deleuze y la obra de Douglas Gordon. Deleuze situaba en Hitchcock la transición entre la imagen-movimiento y la imagen-tiempo. Según Jacobs con 24Hours Psycho Gordon habría creado la imagen-tiempo pura donde la temporalidad está continuamente presente a través de la modificación de la escena original (Jacobs, 2011: 152). Es decir, eliminada la narración, lo que permanece es la temporalidad pura, sin narratividad asociada a ella.

Afirma Frank Bascombe, el protagonista de "El periodista deportivo" del estadounidense Richard Ford: "El misterio es la atractiva condición de que algo -un objeto, un acto, una persona- posee cuando lo conoces un poco, pero no del todo. Es la doble promesa de lo desconocido, impresiones, ideas, sospechas...Y hay que ser lo bastante listo para no explorar todo eso en profundidad, pues correrías el riesgo de darte de bruces con los simples hechos" (2003: 113). Es precisamente esa doble promesa de lo desconocido la que rompe Douglas Gordon. A cámara lenta, la secuencia de la ducha, conocida por propiciar la muerte de la protagonista al comienzo de la película, pasa de ser misteriosa a ser casi pornográfica en el sentido de todo lo que la imagen nos cuenta. Al no permitir al espectador distanciarse, la imagen, como afirmaba Steven Jacobs, permanece temporalidad pura. Y, sobre todo, le resta su carácter aurático como escena clave de la obra. A cámara lenta, la escena es otra escena más dentro de las insoportables veinticuatro horas de Psicosis.

Esa ralentización de la imagen es, además, propia del periodo posguerra en Estados Unidos como síntoma de esa desconfianza hacia el futuro, hacia la temporalidad heredada de la Modernidad y que resultó si no falsa, al menos poco comprometida con sus promesas.

\section{Cómo construir una historia de la tecnología: False Color Action de Tony Ousler}

Cuando en 1959 dos artistas tan diferentes como Wolf Vostell y Name June Paik dieron comienzo al videoarte, ya estaban, en cierta 
forma, expandiendo el concepto de arte al soporte del vídeo. Precisamente lo que ambos artistas realizaron fue perpetuar el legado de Duchamp y su descontextualización de la obra de arte. Si un urinario podía ser una obra de arte, ¿por qué no iban a serlo un conjunto de televisores? Como afirma Laura Baigorri "allí donde pretendían llegar, Duchamp ya había estado antes" (Baigorri, 1997: 28).

Los propios artistas fueron conscientes de la influencia de Duchamp, por lo que la utilización del vídeo fue también una forma de distanciarse y de paliar la angustia de las influencias. Afirmaba Name June Paik: "Estoy convencido. Marcel Duchamp lo hizo todo excepto el vídeo. Creó una gran puerta de entrada y una pequeña puerta de salida. Esta puerta es el vídeo. Por ella se puede salir de Marcel Duchamp” (Baigorri, 1997: 28).

Nacido de la unión entre la televisión y el cine experimental, el videoarte heredó las técnicas formales de este último, entre ellas la experimentación con la temporalidad. Gran parte de la obra de Bill Viola, quizá el videoartista más conocido en la actualidad, es un ejemplo de ello.

Pero, además, se produjo dentro del videoarte un nuevo tipo de expansión: la videoescultura, que aprovechaba los volúmenes de los soportes del vídeo para crear conjuntos arquitectónicos (como aquellos por los que es célebre Nam June Paik).

Entre esos pioneros que extendieron el videoarte más allá de sus límites se encuentra la obra de Tony Oursler, que combina la videoescultura con la tecnología multimedia. Como gran parte de los primeros videoartistas, su obra se centra en la crítica a los medios de comunicación. Sobre formas escultóricas dispares proyecta caras y ojos de personas gritando; una combinación que produce una atmósfera inquietante y grotesca.

Su obra, además de realizar esa expansión, está orientada igualmente a una nueva forma de narrar la historia; una forma acorde con el giro 
temporal producido en las sociedades occidentales. En el año 2012 expuso en Madrid en la galería Soledad Lorenzo su obra "False Color Action" en la que mostraba su visión de la historia de las nuevas tecnologías y cómo habían afectado a los procesos comunicativos de los seres humanos.

La forma en la que la instalación de Oursler concebía la historia no era lineal, sino que la realizaba a través de una especie de collage multimedia donde predominaban figuras extrañas y cabezas humanas encerradas en una esfera transparente. La forma del collage era una metáfora perfecta de cómo se concibe la temporalidad en la época de las nuevas tecnologías. Precisamente Walter Benjamin concebía la construcción del régimen historicista de una forma caleidoscópica y no como una sucesión de hechos. Como afirma Didi-Huberman sobre la teoría de Benjamin: "Esta estructura caleidoscópica, repitámoslo, no puede en ningún caso dejarse reducir a una práctica específica. El caleidoscopio, en Benjamin, es un paradigma, un modelo teórico. Significativamente, surge en los contextos donde es interrogada la estructura del tiempo. Bajo el ángulo de la variedad tornasolada de sus combinaciones, el caleidoscopio caracterizará, por ejemplo, a la modernidad según Benjamin. Bajo el ángulo de la simetría apremiante de sus espejos, el caleidoscopio caracterizará el "curso de la historia" destinado, un día u otro, a romperse entre las manos del niño (es decir, del revolucionario)" (Didi-Huberman 2005: 191). Para Walter Benjamin la Historia debía ser fragmentativa, formada por retazos dispares que se ensamblaban a modo de collage. Para él, la memoria era de naturaleza conservadora, mientras que el recuerdo tendía al caos. La Historia debía construirse mediante recuerdos, a través de retazos, y abandonar la tendencia conservadora.

Las semejanzas con la teoría de Benjamin pueden apreciarse en las propias palabras de Tony Oursler, quien también se ha referido al caleidoscopio para explicar la naturaleza histórica de su obra. El artista en una entrevista realizada a El Cultural afirmaba que su obra trataba "de la naturaleza existencial del ser humano y el nuevo rol que tienen nuestras relaciones ante la red de telecomunicación que cambia día tras día. Vivimos en una continua lucha por ir hacia adelante y 
hacia atrás en lo tecnológico [...]. Es un efecto caleidoscópico". ${ }^{2}$ Las nuevas tecnologías fomentan una temporalidad sincrónica. La red es una especie de cartografía de la temporalidad donde se aúnan presente y pasado y, en menor medida, el futuro. Esta cartografía forma parte de la historia de los medios de los nativos digitales quienes han crecido y crecerán mediados por esta fragmentación. En "False Color Action" Tony Oursler establecía un puente entre dichas temporalidades. Por una parte, la objetualidad del universo real. Y por otra lo inmaterial de la historia virtual. La unión de ambas creaba un espacio heterócrono donde las distintas temporalidades estaban en lucha entre sí. Es importante ese espacio de dialéctica entre varias temporalidades en cuanto a que en las imágenes mediáticas el espectador encuentra una especie de identificación que se inserta en nuestro inconsciente y que no sigue una estructura ordenada, sino que reaparece en forma de fragmentos inconexos. Surge y desaparece.

Tanto la obra de Douglas Gordon como las videoesculturas de Tony Oursler y su historia de la tecnología nos muestran cómo ha afectado el rechazo de la concepción teleológica de la historia en el ámbito del arte y en la sociedad (el arte no es más que la representación de aquello que ocurre a nivel social). La fragmentación, característica propia de la posmodernidad, supone un rechazo del futuro como incierto y amenazante y la apertura a nuevas temporalidades más acordes con el mecanismo por el que funciona el recuerdo y las propias vivencias de los individuos.

\section{Referencias bibliográficas}

Aristóteles (2004). Poética. Madrid: Alianza.

Baigorri, L. (1997): El vídeo y las vanguardias históricas. Barcelona: Universidad de Barcelona.

Benjamin, W. (2005): El libro de los pasajes. Madrid: Akal.

\footnotetext{
${ }^{2}$ Disponible para consulta online: http://www.elcultural.es/noticias/buenosdias/Tony-Oursler/2892)
} 
Bourriaud, N. (2009): Altermodern: Tate Trienal. London: Tate Publishing.

Didi-Huberman, G. (2005): Ante el tiempo. Historia del arte y anacronismo de las imágenes. Buenos Aires: Adriana Hidalgo.

Ford, R. (2003): El periodista deportivo. Barcelona: Anagrama.

Horacio (1999): Ars poética. Arte poética. Cáceres: Universidad de Extremadura.

Jacobs, S. (2011): Framing Pictures. Film and the Visual Arts. Edinburh: Edinburgh University Press.

Jardi, E. (1968): Otro Laoconte: reflexiones sobre los limites de las artes plásticas. Madrid: Aguilar.

Kermode, F. (1983): El sentido de un final. Estudios sobre la teoría de la ficción. Barcelona: Gedisa.

Krauss, R. (2008): "La escultura en su campo expandido". En Foster, H., La posmodernidad. Barcelona: Kairós.

Lessing, G. E. (1977): Laocoonte. Madrid: Nacional.

Lipovetsky, G. (2006): Los tiempos hipermodernos. Barcelona: Anagrama.

Martínez, A.(2000): De Andy Warbol a Cindy Sherman. Valencia:

Universitat Politècnica de Valencia.

Moxey, K. (2013): “Is Modernity Multiple?”, en Visual Time. The Image in History. Durham: Duke University Press

Racionero, L. (2001): Oriente y Occidente. Filosofía oriental y dilemas occidentales. Barcelona: Anagrama.

Ross, C. (2014): The Past is The Present; It's The Future Too. New York and London: Bloomsbury.

Truffaut, F. (2001): El cine según Hitchcock. Madrid: Alianza.

Warburg, A. (2010): Atlas Mnemosyne. Madrid: Akal.

Youngblood, G. (1970): Expanded Cinema. Nueva York: Dutton. 



\title{
Arte Corporal, Fotografía y Televisión
}

\author{
Celia Balbina Fernández Consuegra
}

\section{Introducción}

$\mathrm{E}$ $\mathrm{L}$ reconocimiento de la tecnologización del yo, sobre todo en las décadas de 1980 y 1990, unido a la producción del simulacro del yo, guarda relación con una larga lista de artistas que trabajan los efectos fragmentados de las tecnologías de la era industrial, en base a la experiencia con el propio cuerpo. Entre ellos Stelarc, el gran Cyborg del Body Art, y otras artistas vinculadas al movimiento feminista como Senga Nengudi, Kiki Smith, Lauren Lesko y Rona Pondick.

El vídeo, en el desarrollo del hoy llamado Performance Art o Arte de Acción, y el teatro experimental de los años sesenta y setenta, modifica la acción artística y la escena para un nuevo planteamiento artístico y teatral que renueva sus estructuras, que cuestiona la mirada, el punto de vista y la posición del espectador en el acto creador, pues el arte es esencialmente una continua retroacción entre el emisor y el receptor.

El teatro experimental, con el objetivo de traspasar límites recupera a Artaud, el jeroglífico corporal de Grotowski, evita la dramaturgia aristotélica y acumula artes anexas, en el sentido de teatro total de Wagner. Pero la verdadera novedad introducida por el vídeo y la fotografía en el Arte de Acción y en el teatro, sobrepasa los límites del 
dispositivo cinematográfico y tiene que ver con el desdoblamiento de las escenas en tiempo real, con su multiplicación en el espacio y con el protagonismo del espectador, involucrándolo de forma aún más activa; en Open Score, Rauschenberg utilizó cámaras infrarrojas de televisión para monitorizar el movimiento de un grupo de figurantes, en Two of Wather de Robert Whitman, y Alex Hay, y en Graa Field, emplearon proyectores de televisión en pantalla gigante para amplificar detalles de las acciones; en The Electronic Hammlet (1979), Wolf Vostell utilizó un total de 150 televisores en un circuito cerrado sobre el escenario colocando más de cien monitores sobre las butacas y en Intolleranza, de Luigi Nono, Josef Svóboda empleó cámaras de televisión y tres pantallas en el escenario sobre las que proyectaba en directo, las imágenes del público (Baigorri Ballarín, L. 1997: 74).

Después de los sesenta, un nuevo producto multimedia se consolidaría potenciando, no solo el carácter escenográfico de la obra, sino que concebía la tecnología como parte intrínseca. En este sentido, la vídeo instalación es una de las prácticas que más se ha aproximado al complejo concepto de 'obra de arte total': espacio y tiempo, imagen (fotografía/cine/video), sonido/música, objeto/escultura, iluminación, recorrido, participación, incluso poesía, pintura, texto, acción y representación.

Debido a la flexibilidad del vídeo y la fotografía como medios, ofreció a un numeroso grupo de mujeres, entre ellas, Dara Birnbaum, Ana Mendieta, Adrian Piper, Ulrike Rosembach y Hannah Wilke, la posibilidad de desarrollar un lenguaje propio sobre su identidad y las condicionantes de género y sexismo. Artistas como Pipilotti Rist, Amy Jenkins, Alex Bag y Shirin Neshat, continuaron en este sentido, explorando los estereotipos, los temas de sexo y raza a través de lo hoy llamado fotoperformance y videoperformance.

En otros sentidos y registros muy diferentes, Mattheuw Barney, Briton Steve Moqueen, William Wegman, Dan Graham, Gary Hill, Stan Douglas, Bill Viola y Tony Ousler, generaron grandes obras en los límites de la creación audiovisual. 
En los años ochenta, empezó a surgir una nueva generación de artistas especializados en vídeo, fotografía y nuevos medios, en la que el artista ya no estaba detrás de la cámara o como actor, sino como productor o editor. La muerte del vídeo analógico y el nacimiento del video digital, ha desplegado recursos y medios ilimitados para una creación sin fronteras.

Por otro lado, la proliferación de nuevos instrumentos tecnológicos en la era cibernética y la aparición de redes informativas, además de la multiplicación de la presencia virtual del cuerpo en Internet, ha diluido, en parte, la fuerza del Arte Corporal.

\section{Objetivos e hipótesis de partida de la investigación}

El objetivo de este trabajo, se centra en estudiar el Performance Art cuando utiliza como lenguaje de expresión el ‘cuerpo tecnológico’ en cuanto a la fotografía y al medio televisivo; esto significa, que haremos un análisis, a través de ejemplos concretos, de piezas hechas por determinados artistas que han utilizado estas tecnologías en el desarrollo y evolución de este género artístico.

Fotografía y televisión son los medios tecnológicos que tenemos en cuenta en esta investigación, ya que los ejemplos que analizamos son performances que se han producido antes del surgimiento y desarrollo de otras tecnologías, como por ejemplo el Internet.

Para realizar esta reflexión, se tienen en cuenta las piezas de performances realizados por los artistas que han utilizado estas tecnologías, aquellos que nos han mostrado, a través de su cuerpo, del Arte Corporal como Performance Art, la tecnologización y simulacro del yo, la fragmentación de la identidad, los condicionantes de género y sexismo, el paso del tiempo, las relaciones espaciales entre la gente y las cosas, entre uno mismo y el mundo, la exploración de los estados psicológicos, físicos y emocionales mas básicos y la interacción entre las personas, tomando en consideración esa características del género donde el público es también participante de la acción. Aunque la utilización de estas tecnologías tuvieron una gran importancia en el teatro experimental de los años sesenta y setenta, no contemplamos su análisis en esta investigación. 
Por tanto, la hipótesis de partida giraría en torno a la siguiente pregunta: ¿Es la utilización de la fotografía y la televisión tecnologías que sólo pueden ser utilizadas con el único propósito de registrar un acontecimiento artístico, o también pueden ser utilizadas para reformular y crear nuevas obras con discursos definidos dentro del género Performance Art?

Para contestar esta pregunta, realizamos un análisis de las obras realizadas por determinados artistas, aquellos que fueron los pioneros en utilizar estos medios.

En las conclusiones de esta investigación se demostrará que, el uso de las tecnologías antes citadas en la realización de piezas de Performance Art, verdaderamente fueron medios que originaron un nuevo tipo de performance, el Performance Art Tecnológico: fotoperformance. Las incursiones del Arte Corporal dentro de la televisión, no generaron un nuevo género como en el caso de la fotografía, pero tenemos en cuenta en esta investigación las aportaciones de esta tecnología, aun cuando pudieran ser consideradas, por los lectores, no dignas de tenerse en cuenta.

\section{Metodología de la investigación}

Para llevar a cabo esta investigación se ha tenido como marco teórico la Antropología Simbólica.

La Antropología Simbólica que desarrolla Víctor Turner (1986), posee un enfoque que radica en el estudio de las diferentes formas que las personas entienden e interpretan su entorno, así como, en las acciones y expresiones de otros miembros de su sociedad. Estas interpretaciones forman un sistema cultural compartido de significados, que varía entre los miembros de una misma sociedad. El Análisis Simbólico Procesual, metodología de análisis de la Antropología Simbólica, estudia los símbolos y los procesos (el ritual) a través de los cuales, los seres humanos asignan un significado a esos símbolos, para abordar las cuestiones fundamentales de la vida social humana y del arte, como reflejo de las condiciones político-sociales de la estructura normativa. Por ejemplo, los performances creados 
por los artistas que analizamos en esta investigación, son acciones, que manejan símbolos que hablan de cómo es la sociedad, por lo que los símbolos son reflejo de la cultura y la propia sociedad. Todo el Arte Corporal como lenguaje del Performance Art, utiliza símbolos para mostrar temas diferentes dentro de las sociedades normativas: los derechos de la mujer, los derechos de los gays, las denuncias políticas, los desaparecidos en guerras o por dictaduras como ha ocurrido en Latinoamérica, la reivindicación de los enfermos de sida, etc.

La Antropología Simbólica aplicada al Arte Corporal, que desarrollan determinados artistas, analiza los símbolos y las metáforas que crean esos artistas en sus acciones, muchas veces rituales, que son reflejo de las condiciones sociales, políticas e ideológicas de la sociedad a la que pertenecen y, que por supuesto, también refleja el arte. No podemos pasar por alto, que cada cultura y cada persona dentro de ella, utiliza todo el repertorio sensorial para comunicar mensajes: gesticulaciones manuales, expresiones faciales, posturas corporales, lágrimas y movimientos coordinados con los demás. Así mismo, la evolución de la historia y del arte, se analiza bajo lo que Turner define como drama social. Un drama social no es una estructura atemporal, sino un proceso que se desenvuelve en el tiempo. Como tal, entonces, posee una estructura, pero no una estructura de elementos espacializados de alguna manera, sino de relaciones en el tiempo, una secuencia de fases. Teniendo esto en consideración, se pueden analizar las fases que articulan la historia y la evolución del arte en el siglo XX.

Desde la perspectiva Turner, no hay que conceptualizar a los símbolos como objetos, sino como instrumentos para la acción, dentro de un contexto y en el marco de los procesos sociales. Los símbolos aparecen, entonces, como componentes de la acción social, vinculados a los intereses humanos, propósitos, fines, medios, aspiraciones e ideales, individuales y colectivos. Además, los símbolos no son estáticos, sino que se encuentran abiertos a las dinámicas de cambio social. Y por supuesto, muchos símbolos han sido creados a través de las tecnologías que se tienen en cuenta en esta investigación. 


\section{El Arte Corporal y la Fotografía}

Durante muchos años, el registro fotográfico fue utilizado por los artistas conceptuales para documentar la ejecución de obras y eventos de carácter efímero. La fotografía, era la evidencia de una realización artística, su corroboración y verificación - en la medida en que postulaba su valor de verdad - para la posteridad, transformándose en prueba fehaciente de la intervención de su autor en la ejecución.

Ana Mendieta, siguió un camino algo diferente para el registro de sus acciones sobre la naturaleza. Su trabajo se basó en la intervención sobre espacios naturales, en los que dejaba esbozada una silueta que luego registraba fotográficamente. Sin embargo, sus registros no dan pruebas de su presencia sino más bien de su ausencia: no muestran a Mendieta en el acto de señalizar el espacio sino que documentan el producto posterior del mismo, el momento en que su autora ha quedado reducida a una huella en el paisaje.

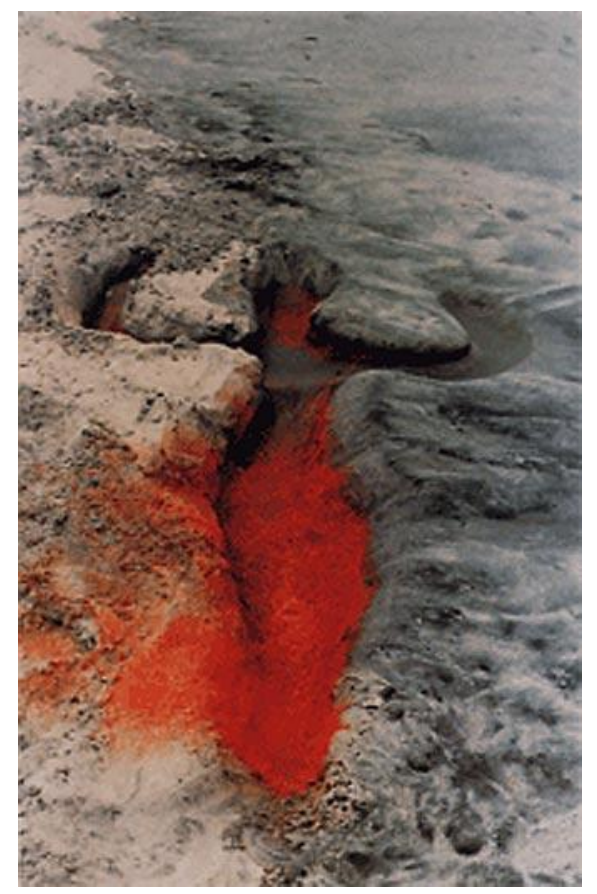

Silueta en pigmento rojo sobre arena. Ana Mendieta. México. 1976

La imagen fotográfica refuerza esa ausencia debido a su estatuto de pasado irremediable e inmodificable, que según Barthes, subyace en toda fotografía. 
"La fotografía sólo adquiere su valor pleno con la desaparición irreversible del referente, con la muerte del sujeto fotografiado, con el paso del tiempo" (Barthes, 1995: 23).

Pero a su vez, es la ocasión de la recepción estética de la obra, que sólo puede desplegarse para el espectador entre la autenticidad del registro y la ausencia del acto.

Aunque documento de un sub-producto (la huella), el registro es parte integrante y vital del performance. Su lugar claramente no es complementario, ya que es imposible establecer un límite preciso entre performance y registro que pudiera caracterizar a uno y otro como prácticas separadas. Las fotografías son el único vínculo que Mendieta propone para el espectador, obligado a aproximarse a la inmediatez del acto original, desde la perspectiva mediada del registro fotográfico.

El fotoperformance -procedimiento basado en acciones pensadas especialmente para ser registradas- dio lugar a un tipo de obras donde el acto aparece como inseparable de su traducción mediática. La secuenciación del registro fotográfico, permitió además, alterar los patrones temporales propios del acto performático o focalizar la recepción del mismo, con la posibilidad de generar un metadiscurso crítico en relación al proceso de ejecución de la obra.

Como caso particular de este tipo de trabajos, puede señalarse los registros de los performances de Orlan. Los registros, son el resultado de una situación especialmente escenificada para la cámara, sobre la que Orlan también suele intervenir, posteriormente en la edición. Además del registro en sí, muchas veces las condiciones mismas de su presentación están contempladas en función del performance: en la última Bienal de Lyon, por ejemplo, Orlan dispuso televisores con las imágenes de sus operaciones en el techo del Museo de Arte Contemporáneo de esta ciudad, al lado de un dispositivo de luces similares a los que se utilizan en las salas de cirugía sobre las mesas de operación. De esta forma, el espectador estaba obligado a mirar hacia arriba y directamente a las lámparas, de la misma manera en que la artista lo había hecho durante la intervención quirúrgica. 
Esta tendencia crítica, se encuentra también en la obra de otros artistas, que generan situaciones donde el énfasis está puesto en una deconstrucción de los medios con los que trabajan, y que en la mayoría de los casos, han focalizado su atención sobre los sistemas de valores propagados por esos mismos medios en el ámbito de la cultura contemporánea.

Las obras de Cindy Sherman y Yasumasa Morimura son características de este tipo de trabajo. En sus personificaciones, Sherman ha tomado los estereotipos de mujer popularizados por el cine y las revistas de moda, para generar una crítica sobre la influencia de los medios en la conformación de dichos estereotipos y cuestionar al mismo tiempo al propio medio como productor de ese universo artificial. Pero al apropiarse del imaginario producido por los medios, su crítica se prolonga hacia cuestiones más radicales en relación a la originalidad y la creatividad de la práctica artística. Como expresa Rosalind Krauss: "Habiendo entendido a la fotografía como el Otro del arte, su uso de la fotografía no comporta un objeto para la crítica artística sino que se constituye como un acto crítico. Constituye a la fotografía misma como un metalenguaje con el cual opera sobre el campo mitogramatical del arte, explorando a un tiempo los mitos de la creatividad y visión artísticas, y la inocencia, primacía y autonomía del 'soporte' de toda imagen estética' (Krauss, R. 1990b: 98).

Yasumasa Morimura, mediante una práctica muy similar, no sólo cuestiona la supremacía de occidente en el dominio de la imagen mediada, sino que también relativiza la fijeza de los géneros producida por ese sistema, al personificarse preferentemente como representante del sexo opuesto.

Morimura, realiza fotografías a gran escala disfrazándose de personajes tan variopintos como Scarlett O'Hara, Greta Garbo, Che Guevara, hasta los protagonistas de obras maestras de la Historia del Arte como Saturno Devorando sus Hijos, o Duchamp disfrazado de mujer en las imágenes de Rrose Sélavy en 1921.

Un trabajo donde Morimura explora la percepción que tiene el mundo occidental del oriental es Retrato (Futago), donde se apropia de la Olimpia de Manet, uno de los símbolos principales de la tradición 
de la cultural occidental, representándose como la Olimpia y como la criada negra. El travestismo del artista y la contextualización como mujer, desafía la construcción colonial de 'Asia como mujer', y los hombres asiáticos como afeminados; el artista hace que el espectador occidental cuestione y reevalúe sus percepciones sobre la identidad cultural asiática.

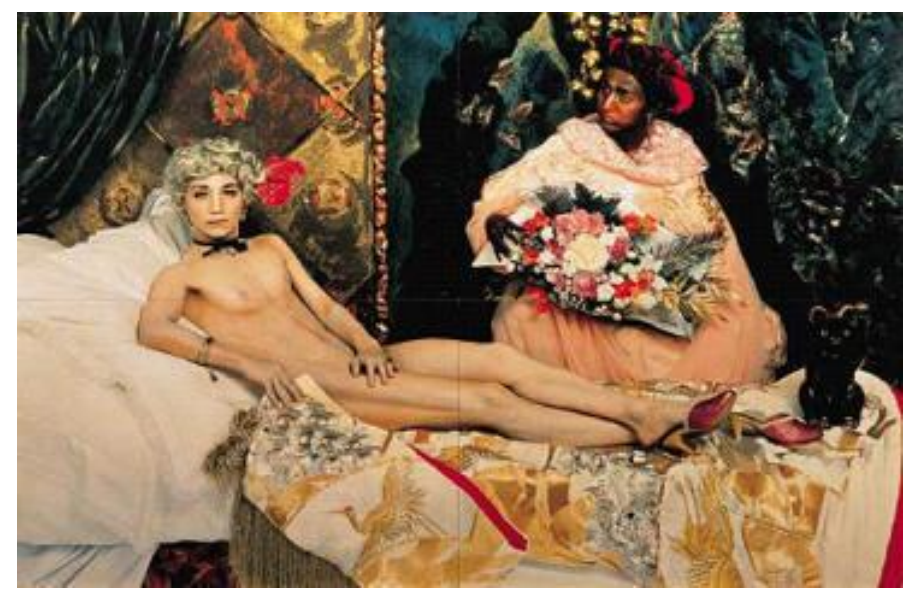

Retrato (Futago)

Yasumasa Morimura. 1988.

Fotografía

Retrato (Futago), también intenta desafiar las percepciones tradicionales sexuales de las culturas minoritarias. Como artista gay, Morimura utiliza el travestismo en su emplazamiento como Olimpia, para subrayar el estereotipo gay como afeminado. A través de este estereotipo, explora la forma en que su propia identidad cultural se construye, generalizando los convencionalismos sociales. Al mismo tiempo, es evidente que esta Olimpia es un hombre, por ello subraya la artificialidad de tales estereotipos y desafía su validez. Adicionalmente, su ubicación como mujer desestabiliza los fijos y binarios roles de género hombre-mujer que prevalece en la cultura existente, por lo que construye una nueva identidad de género, donde los estereotipos de hombre y mujer están subvertidos.

Por otro lado, desarrollando una relación extraordinaria con su cámara, Cindy Sherman ha sido capaz de manipular drásticamente su edad y su peso, convirtiéndose en irreconocible ante el público. En sus trabajos, que se mueven entre lo alarmante y lo desagradable, lo divertido y lo conmovedor, la norteamericana actúa como actriz, directora, modelo y artista. 
Aunque su formación primera como artista fue en el campo de la pintura, la fotografía atrajo pronto su atención, convirtiéndose con el tiempo en una figura clave en este área por su particular manera de potenciar nuevas posibilidades. Pero el hecho de que Sherman utilice su propio cuerpo como vehículo para introducir diferentes personajes, inventar roles e interpretarlos, y de que combine su faceta de modelo con la de directora de cine, abre además un amplio abanico de opciones creativas que de cara al espectador se traducen en que los límites se desdibujan y se amplían: la idea de posar se confunde con la de mirar, el objeto con el sujeto.

Además, Sherman se crea a sí misma incesantemente, sin embargo, no trata de revelar el verdadero yo artístico, sino evidenciar cómo la identidad es una construcción imaginaria y ambigua que se convierte en actriz y creadora de la propia narración que exhibe. Las fotografías que Sherman comenzó a realizar desde 1977, nos enseñan la agonía del estereotipo, la deconstrucción de la identidad y su plasmación en el caos, planteando, al mismo tiempo, las consecuencias de la mujer simplificada culturalmente como una dualidad: sujeto/objeto.

Con la multiplicación de su imagen, Cindy Sherman renuncia a tener la suya propia. Sus fotografías no pueden ser consideradas como autorretratos, dado que ninguna de ellas la refleja. Las mujeres que aparecen en sus fotografías no existen, no son retratos de nadie, pero, paradójicamente, representan de manera fehaciente la imagen estereotipada de la mujer en la sociedad occidental contemporánea. Sus múltiples rostros representan la deconstrucción de la imagen femenina, un producto de la representación caracterizado, desde un punto de vista falocéntrico, por la inestabilidad, la pérdida de identidad, la ausencia y la mascarada. En la sociedad occidental, la mujer se ha convertido en el objeto pasivo de la mirada del hombre, el cual proyecta sobre ella sus fantasías y sus deseos más o menos inconscientes, haciéndola vulnerable y frágil, poniéndola bajo su control. 


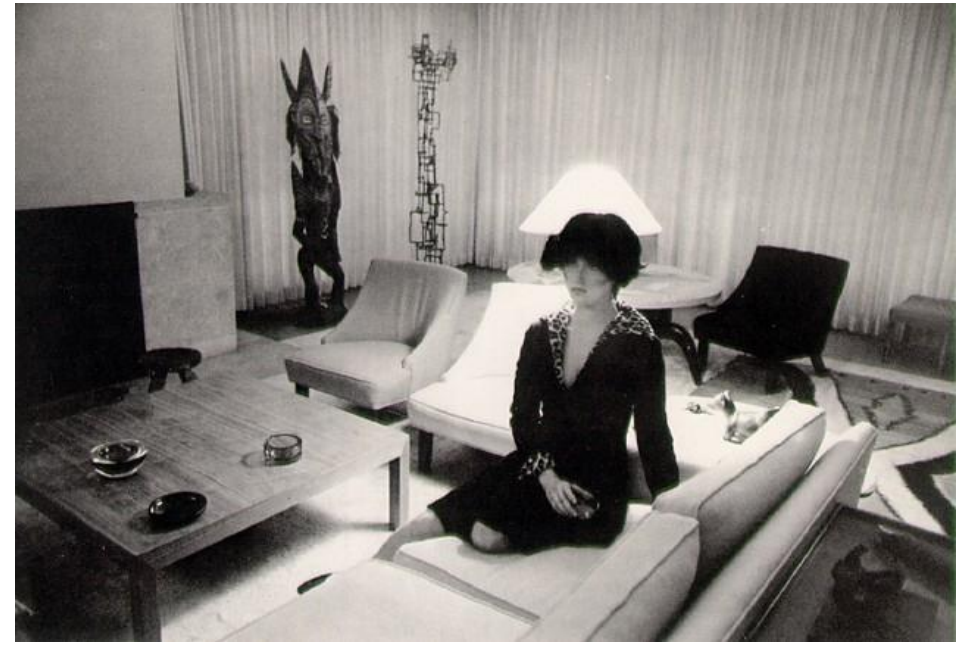

Sin título $N^{o} 15$. Cindy

Sherman. 1979

Serie Untitled Film Stills.

Colección privada

Entre sus fotografías, hay que destacar la presencia de series como Untitled A-E (1975), buen ejemplo de sus primeros años, Bus Raider (1976-2005), Murder Mystery (1976-2000) y Untitled Film Stills (19771980), una serie que ofrece un variado repertorio de roles femeninos inspirados en fotogramas cinematográficos y donde es más evidente su trabajo de simulacro crítico de estereotipos. Entre los personajes de esta serie, destacan, una mujer en ropa interior con un vaso de Martini en la mano, una bibliotecaria de aspecto dulce, una secretaria, una mujer provocativa de la clase baja de una película neorrealista italiana y varias mujeres de clase media en sus cómodos apartamentos (VV.AA. 1997b: 171-196).

En la serie de sus 'retratos históricos', una idea derivada de un encargo de una fábrica de Limoges que producía prótesis de porcelana a partir de moldes originales del siglo XVIII, Cindy Sherman se autorretrató inspirándose en grandes obras clásicas, y jugó con disposiciones y símbolos pictóricos muy cercanos a los originales, para subvertir su mensaje al utilizarlos de forma inquietante y alterada. Uno de estos retratos, de 1989, sin título, demuestra el conocimiento de obras célebres del arte medieval tardío, al tiempo que subvierte su significado. Al colocar sobre un rico fondo de cortinajes de encajes su propia imagen con la larga cabellera rubia suelta y con un niño en brazos, evoca, sin lugar a dudas, la primorosa minuciosidad descriptiva de los valores táctiles de la pintura flamenca. Pero es una evocación transgresora. 
La provocación consiste en presentar un pecho artificial sobrepuesto, de porcelana, una prótesis, de la que difícilmente puede manar leche. De este modo la imagen se convierte en una reflexión sobre la maternidad, la lactancia, y, en términos generales, se presenta como un reto contra el papel nutridor adjudicado a las mujeres en la cultura occidental.

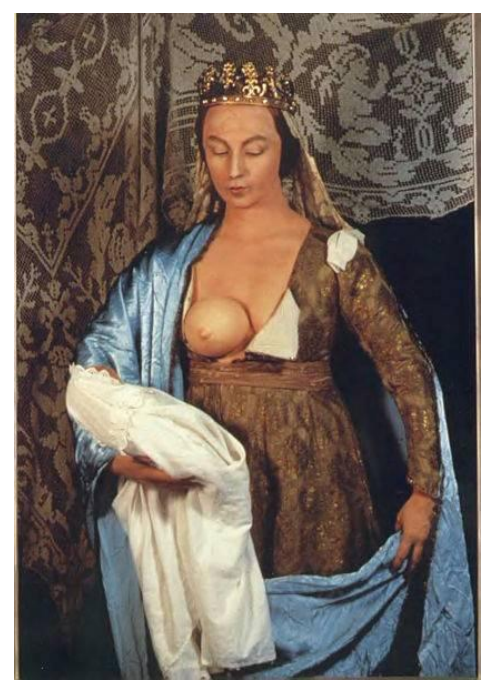

Retrato histórico. Cindy Sherman. 1989.

VV.AA. (2008). Mujeres artistas de los Siglos XX y XXI. Madrid:

Tachen. p.171

Bruce McLean, en Pose Work for Plinths, posó para una cámara fotográfica en distintas posiciones utilizando unos cubos blancos. Luego, las fotografías se montaron como obras independientes y se expusieron un año después como una versión de la acción original. Esta obra se presentó por primera vez en 1970 para la organización Situation, dedicada al arte conceptual británico (Jones, A. and Warr, T. 2000: 86).

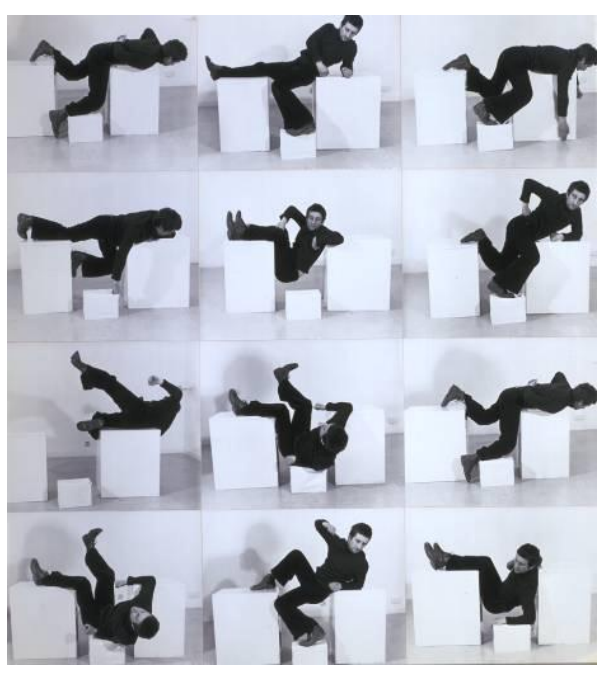

Pose Work for Plinths. Bruce

McLean. 1970

Bruce McLean archives 
Con este performance, McLean reinterpreta la retórica de la escultura tradicional empleando su cuerpo en lugar del habitual objeto artístico, y realiza una parodia de las figuras maternales yacentes de Henry Moore. La pieza también ridiculiza la seriedad de la actitud autorreflexiva del Arte Conceptual, además de aludir a la utilización de la fotografía por sí misma como medio escultórico.

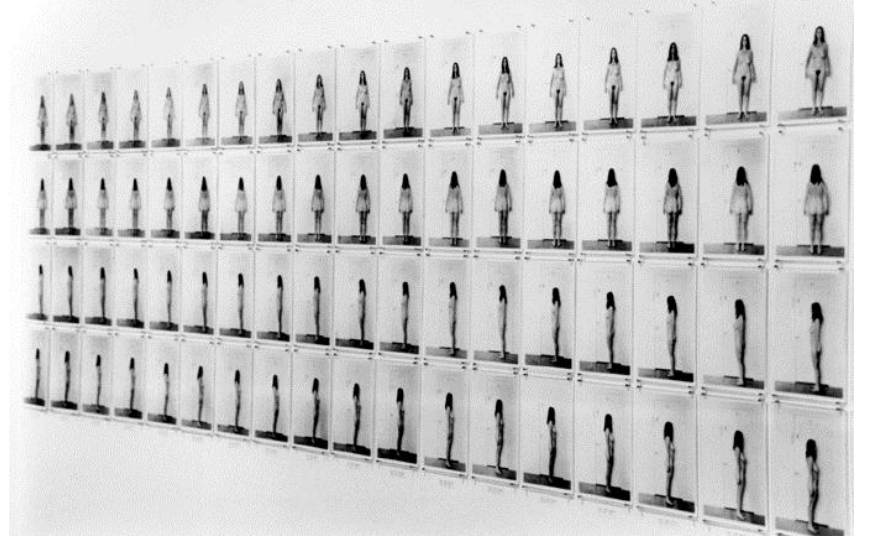

Carving: A Traditional

Sculpture.

Eleanor Antin. 1972.

144 fotos.

Colección Art Institute

of Chicago

Eleanor Antin, en su pieza Carving: A Traditional Sculpture (1972), hizo fotografiar su cuerpo todas las mañanas de frente, de espaldas, perfil derecho y perfil izquierdo, entre el 15 de julio y el 21 de agosto, con objeto de describir el proceso de 'talla' que sufre el cuerpo, durante un régimen alimenticio de adelgazamiento (Jones and Warr, 2000a: 87). Pero en este caso, la talla no se realizaba a la manera de los griegos o de Giacometti, donde el escultor trabajaba los contornos de la figura extrayendo capa tras capa por todos los lados, ahora, la talla se realiza de adentro hacia fuera.

La fotografía fue abrazada durante la década de 1970 como el medio transgresivo por excelencia. Su reproductibilidad mecánica, su denigrado estatus cultural y sus capacidades miméticas, ofrecieron a los artistas un vehículo perfecto a través del cual podían transmitir sus inquietudes sin la necesidad de crear objetos estéticos. Muchos autores se apropiaron del estilo propio del fotoperiodismo para sus esfuerzos de análisis.

La documentación fotográfica, fue adoptada por aquellos artistas que deseaban evitar ciertas convenciones estéticas, pero sobre todo, por 
quienes querían documentar episodios o performances en la privacidad del estudio. De este modo, la acción fotográfica se convirtió en una interesante posibilidad de acceder al otro. Posibilidad, a través de la cual, el artista introduce el medio fotográfico como una documentación susceptible de ser alterada, como un espejismo de quien observa la obra, en una imagen manipulada por el autor en una explosiva estrategia basada en la reflexión sobre el mundo visible.

Muchos artistas utilizaron la multiplicidad de la imagen fotográfica como arte secuencial, lo que permitió expresar y preservar la noción de tiempo. Por ello, la serie fotográfica se convirtió en uno de los modos de expresión más utilizados, con la finalidad de registrar los procesos de reflexión sobre el género. Este seriación, sugiere el intento de fijar una identidad transitoria y fugaz, un intento por captar la imagen del espejo adoptando la identidad que se quiere ser.

Por otro lado, la idea de repetición entendida como la redundancia de una misma imagen, implica directamente la noción de frecuencia informativa. Esta frecuencia de repetición de la imagen, de alguna manera pretende anular la contundencia de la primera lectura que ofrecería una imagen única y aislada. La repetición infinita, o un número de veces suficientemente amplio de un cliché, de una toma fotográfica instantánea del objeto, elimina la eventual magia que podía nacer del valor carismático del símbolo, siendo este aspecto una característica que acontece dentro de una sociedad marcada por la producción en masa.

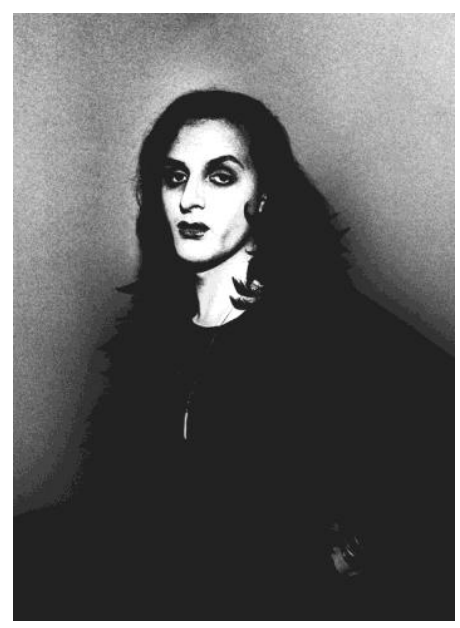

Autorretrato. Urs Lüthi.

1973

Colección privada 
Tanto los individuos de Urs Lüthi, como los de Hannah Wilke, se enfrentan al espectador fingiendo proyectarse hacia el exterior. La serie de Lüthi, The Numbergirl (1973) y Un'isola nell'aria (1975), así como la de Wilke, S.O.S., Starification Object Series (1974), representan series repetitivas de imágenes, reproducidas en forma de cuadrícula.

Urs Lüthi, posaba travestido para la cámara fotográfica en un acto de autocontemplación de su relación íntima con la mujer. Con la destrucción de los estereotipos de género, Lüthi señala que la conexión que siente con lo femenino se encuentra en un lugar profundo de la psique, alejado de la apariencia y el comportamiento sociales. Esperaba que al comunicar lo íntimo en él, el espectador reflexionara sobre sus aspectos personales y contradictorios. Con esta forma de mostrarse, sexualmente ambigua y travestida fingía ser muchos otros, siendo él mismo.

En la serie The Numbergirl, Lüthi posa de forma erótica y sugerente, sosteniendo fotos de él mismo y de espacios arquitectónicos; con cada postura y expresión facial, en un especial repertorio de lenguaje corporal, Lüthi se representa como un fetiche desesperado. Al multiplicar su imagen en un único marco, el artista refuerza el efecto simulado de todo el grupo de imágenes, negando a su vez, la existencia real de su cuerpo-yo.
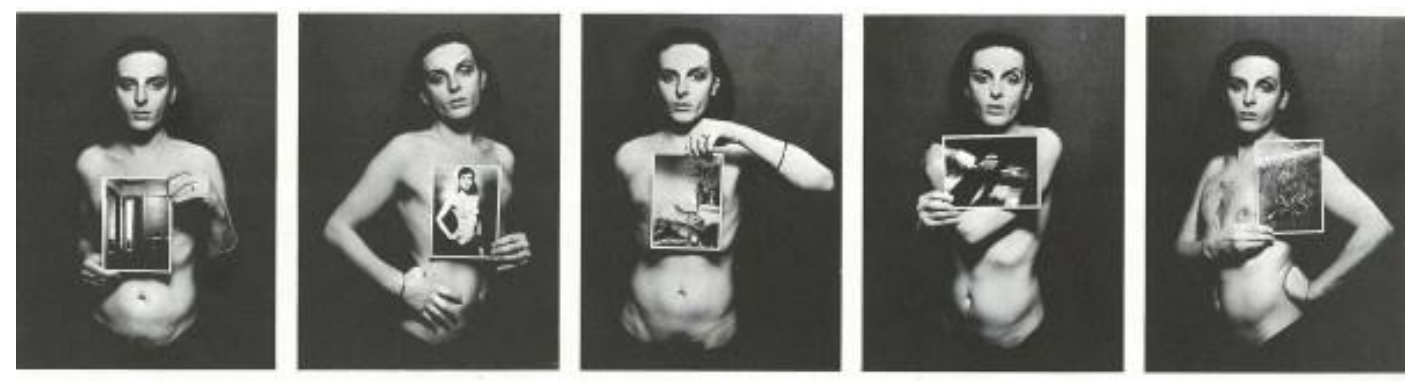

The Numbergirl. Urs Lüthi. 1973. Colección privada

En la serie Un'isola nell'aria, el espacio arquitectónico muestra a Lüthi como un objeto de deseo del coleccionista y donde su condición sexual se multiplica hasta ser irreconocible. Como afirma Lea Vergine: "Lüthi invierte las características somáticas, grotescamente 
acentuando la apariencia de bisexualidad, e inventando personalidades ficticias, creando entonces, una crisis de cristalización de los roles sexuales [...] logra crear una especie de contaminación emocional en el espectador quien induce a convertirse en un socio o colaborador voluntario o involuntario capaz de cerrar el circuito y devolver la misma percepción intercambiable" (Jones and Warr, 2000a: 87).

Lüthi pone en escena un juego simultáneo de ocultación y divulgación del destino individual y social del yo. Con sus fotografías intenta tanto captarse, como perderse, en un intento de querer reconocerse e identificarse, pero dicho acto deviene banal al comprobar su imposibilidad. Al observar su trabajo, quedamos sorprendidos por una dramaturgia dirigida al juego narcisista de alteraciones físicas, afectivas y sociales que son simulacros de la identidad.

Hannah Wilke, fue una de las autoras más representativas de aquel grupo que configuró la primera generación de mujeres que militaron en distinto frente, por primera vez, en la Historia del Arte dominada por la acción y la visión de los hombres, las políticas conservadoras, los prejuicios sociales y las discriminaciones sexistas, y que finalmente, crearon las condiciones para la aparición, no sólo de unas circunstancias igualitarias entre los hombres y las mujeres, sino además, un modo inédito de hacer y entender el arte, por surgir de las manos, de los cuerpos y de las mentes de mujeres. Todo ello condujo a Hannah Wilke a una identificación total entre su arte y su vida.

Los primeros trabajos de Wilke, guardan una enorme coherencia con las reflexiones del incipiente feminismo artístico, del que ella es hoy día referente indispensable. Sus obras iniciales giran en torno a la iconografía vaginal, de la que Wilke fue pionera. Aquellas artistas de los setenta centraron la temática de su arte en sus propios cuerpos, una suerte de autorreferencialidad que terminó por instaurar la vagina como icono fundamental. Pensaban que su vagina era aquello que las convertía en mujeres, y deciden elevarla a los altares por considerar que su representación había sido siempre un tabú dentro de la cultura occidental. 
Látex, cerámica, chicle o goma de borrar, son algunos de los materiales con los que Wilke modeló una multiplicidad de formas vulvares a lo largo de toda su trayectoria artística. Vaginas diferentes unas de otras en formas y tamaños, que aluden a las diferencias entre las mujeres. Algunas las coloca en el suelo de la sala, en clara alusión al Arte Mínimal, otras las pega sobre postales antiguas de edificios y calles emblemáticas de la ciudad de New York. Son pequeñas vaginas modeladas en goma de borrar que invaden la Biblioteca Pública de New York o la tumba del expresidente Franklin en Philadelphia, y que se convierten en metáfora del acceso de las mujeres al ámbito de lo público, como aquel espacio que les había sido sistemáticamente negado. Wilke equipara estas pequeñas vaginas invasoras al movimiento feminista, cuya presencia en las calles de la ciudad era cada vez más evidente.

Lo más destacable de su obra, es que la artista se convierte en objeto de su propio arte, exhibe su cuerpo desnudo, lo expone, permitiéndose incluso el lujo de objetificarlo bajo su atenta mirada, que rompe y subvierte las leyes de la mirada tradicional del patriarcado. Las referencias a la historia del arte se observan tras cada vídeo, tras cada fotografía, demostrando que la artista conocía en profundidad la imaginería occidental.

En S.O.S., Starification Object Series, Wilke asume el papel de esas modelos anónimas que pueblan las campañas publicitarias, imita sus poses artificiales, demostrándonos que son tan sólo gestos estereotipados de 'lo femenino', que, repetidos hasta la saciedad, han terminado por convertirse en norma de feminidad. Mostrando el torso, semi o completamente desnudo, el cuerpo aparece cubierto de vaginas de chicle. Sus poses variadas, teatrales y simuladas participan de la paradoja del marketing de masas de los cuerpos de famosos para deleite de los consumidores.

Este yo con vaginas externas, representa la auténtica simulación del yo que Lüthi deseó obtener en Numbergirl. La exteriorización del interior del cuerpo (las vaginas), señala que es un cuerpo que se encuentra en un flujo permanente de deseos-productos. 


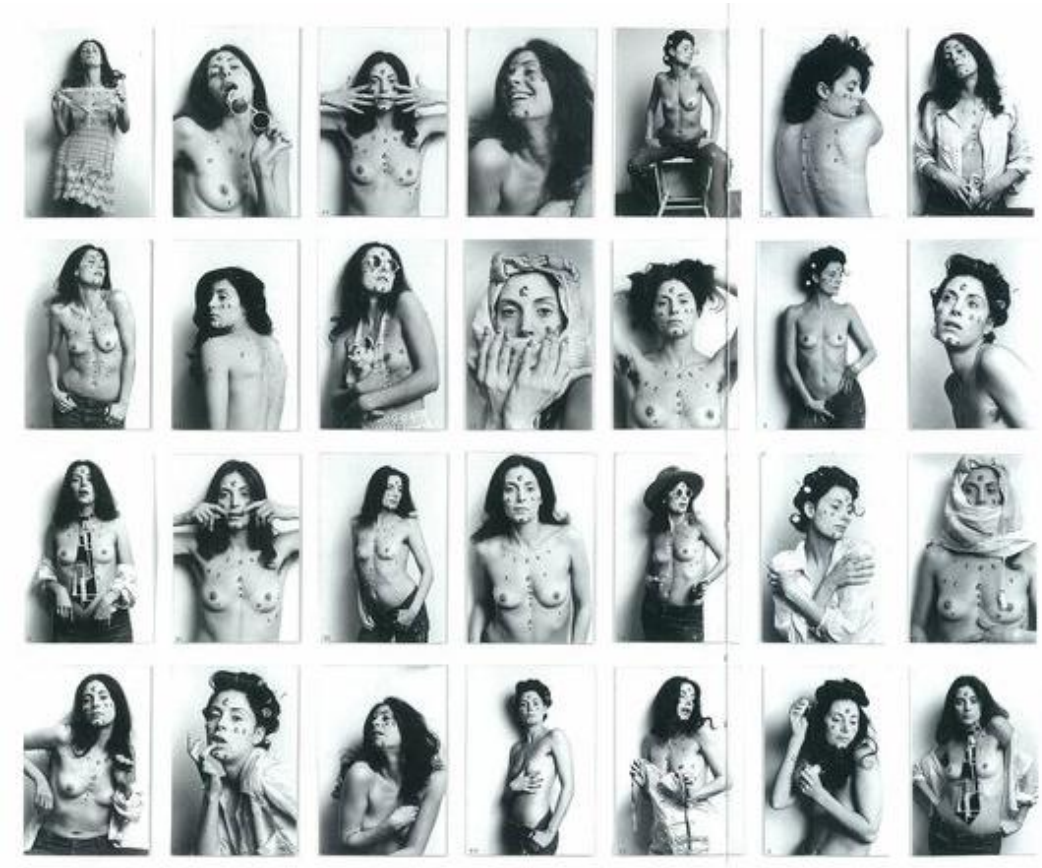

\section{S.O.S., Starification Object Series. Hannah Wilke.1974. Ronald Feldman Fine Arts. New York}

En los primeros años de la década de 1980, Andy Warhol, realizó una serie de autorretratos con una cámara Polaroid. El autor sentía una gran fascinación por los poderes metamorfoseantes de la fotografía. Una foto era para él mucho más que un simple recuerdo: era una herramienta de transformación, una metáfora del consumismo fácil y un objeto de contemplación voyeurista. Todas las fotografías de esta serie son muy parecidas: de frente o de perfil, Warhol posa con una peluca y los labios pintados de un intenso rojo. La actitud en todas ellas es seria, un tanto distante. El fondo blanco, la pose hierática, el rostro anodino y el pequeño tamaño de las obras, nos recuerda las fotografías que se realizan para los carnets de identidad o pasaportes.

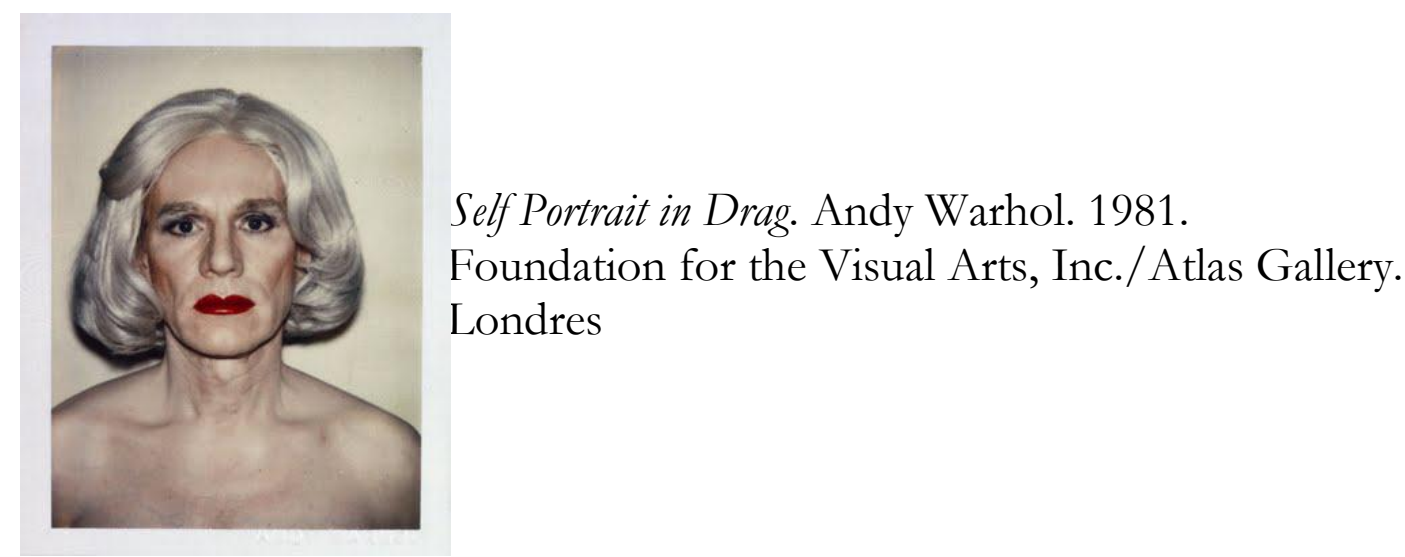




\section{El Arte Corporal y la Televisión}

Desde finales de los años sesenta, muchos artistas, especialmente aquellos que trabajaban en el contexto norteamericano, tuvieron la ocasión de realizar trabajos para diferentes cadenas de televisión. Hasta entonces la televisión había sido utilizada solamente para la emisión de programas de contenido comercial o de entretenimiento, y muchos artistas se resistían a la idea que en ella no tuviesen cabida propuestas e intervenciones artísticas. Veían en la televisión, un medio dominante de alienación capaz de influir en la sociedad y, recurrieron a su misma tecnología, para realizar una crítica de sus contenidos empleando distintas estrategias.

Los deseos de muchos artistas de intervenir en la televisión comercial, se vieron satisfechos cuando algunas emisoras les ofrecieron espacios para la creación. En Estados Unidos, destacan los talleres de cadenas como la WGBH de Boston, que puso en manos de artistas la creación de un programa televisivo que fue emitido en marzo de 1969. A los artistas que participaron, entre los que se encontraba Paik, se les brindó la oportunidad de explorar el potencial creativo del medio. Esto supuso para ellos, la oportunidad de llegar a los hogares de los espectadores sin necesidad de pasar por las estructuras institucionales establecidas: el museo o la galería.

En Europa, en esta misma línea, cabe destacar iniciativas como la que en 1971 desarrolló el británico David Hall para la televisión escocesa. Durante los meses de agosto y septiembre de aquel año, diez obras creadas exprofeso por el artista para la emisora, fueron retransmitidas sin previo aviso y sin títulos de crédito. En mitad de un programa de entretenimiento, una serie o un concurso irrumpía, para el asombro de los telespectadores, una de estas obras: de repente aparecía en pantalla un hombre apuntando al espectador con el objetivo de una cámara, la imagen de un televisor incendiándose en el campo, o un grifo abierto comenzaba a inundar la pantalla de agua (Elwes, 2005: 96-101).

Son intervenciones televisivas encaminadas a llamar la atención del público acerca de la monotonía, la falta de imaginación y la intrascendencia imperantes en la televisión. Pero son algo más que 
eso, ya que además de desvelar la artificiosidad del lenguaje usado por la televisión y sus propuestas comerciales, comenzaron a investigar el uso del tiempo y la imagen que sería desarrollado en años sucesivos por artistas como Bill Viola o Gary Hill. Ofrecía un horizonte nuevo, el de otra televisión posible, más imaginativa y sobre todo más sorprendente y viva.

\section{Conclusiones}

El registro fotográfico deja de ser utilizado por los artistas para documentar la ejecución de obras y eventos de carácter efímero. En muchos performances, las fotografías se convierten en el único vínculo que el artista propone para el espectador, obligado a aproximarse a la inmediatez del acto original, desde la perspectiva mediada del registro fotográfico. Los artistas crean un nuevo sistema de símbolos y, surge entonces, el fotoperformance.

A través de la fotografía, se crean identidades incesantemente, sin embargo, no trata de revelar el verdadero yo artístico, sino evidenciar cómo la identidad es una construcción imaginaria y ambigua que se convierte en actriz y creadora de la propia narración que exhibe.

Muchos artistas utilizaron la multiplicidad de la imagen fotográfica como arte secuencial, lo que permitió expresar y preservar la noción de tiempo. Por ello, la serie fotográfica, como Performance Art, se convirtió en uno de los modos de expresión más utilizados, con la finalidad de registrar los procesos de reflexión sobre el género y sobre la deconstrucción de la identidad.

El fotoperformance es un procedimientos basado en acciones pensadas especialmente para ser registradas, por lo que podemos afirmar que, dio lugar a un tipo de obras donde el acto aparece como inseparable de su traducción mediática. La secuenciación del registro fotográfico permitió además, alterar los patrones temporales propios del acto performático o focalizar la recepción del mismo, con la posibilidad de generar un metadiscurso crítico en relación al proceso de ejecución de la obra.

La inclusión de la fotografía como medio representacional del Performance Art, contribuyó a originar un nuevo tipo de 
performance, el Performance Art Tecnológico en su acepción de fotoperformance. ${ }^{3}$

El uso de la televisión como medio representacional en el Performance Art, no generó un nuevo tipo de Performance Art Tecnológico, sólo contribuyó al desarrollo, evolución y divulgación de este género artístico.

\section{Referencias bibliográficas}

Agúndez García, J. A. (1999): 10 Happenings de Wolf Vostell. Mérida: Editora Regional de Extremadura. Colección Artes Plásticas

Auslander, P. (2005): Liveness. Performance in a Mediatized Culture. New York: Routledge

Aznar Almazán, S. (2000). El arte de acción. $2^{\mathrm{a}}$ ed., San Sebastián: Nerea Baigorri Ballarín, L. (1997): El Video y las Vanguardias Históricas. Barcelona: Universitat de Barcelona

Baigorri Ballarín, L. (2005): Video: Primera etapa. Madrid: Brumaria

Barthes, R. (1995): La Cámara Lúcida: Nota sobre la Fotografía.

Barcelona: Paidós

Benjamín, W. (1991): La Obra del Arte en la Época de la Reproductibilidad Técnica. Madrid: Taurus. pp. 59-76

Blessing, J. (1997): Rrose is a Rrose is a Rrose. Gender Performance in Photography. New York: Solomon R. Guggenheim Museum

Blocker, J. (2004): Where Is Ana Mendieta?: Identity, Performativity, and Exile. USA: Duke University

Dixon, S. (2007): Digital Performance: A History of New Media in Theater, Dance, Performance Art, and Installation. USA: The MIT Press

Giesekam, G. (2007): Staging the Screen: The Use of Film and Video in Theatre (Theatre and Performance Practices). USA: Palgrave Macmillan

Goldberg, R. (2002): Performance Art. Barcelona: Destino

\footnotetext{
${ }^{3}$ El video también contribuyó al origen del Performance Art Tecnológico: videoperformance
} 
Guggenheim, Museum. (1998): Robert Rauschenberg. New York:

Guggenheim Museum Publications

Guinot, O. (2002): "El arte se hizo carne... y se llamó Orlan" en el catálogo de la exposición Orlan. 1964 - 2001. Álava, ARTIUM Universidad de Salamanca

Hernández Sánchez, D. (Ed.) (2003): Arte, Cuerpo, Tecnología.

Salamanca: Universidad de Salamanca

Jonas, Joan. (2000): Performance Film Istallation. New York: Hatje Cantz Publishers

Jones, A. \& Warr, T. (2000a): The Artist's Body. London: Phaidon

Press Limited

Jones, A. (2000b): Body Art/Performing the Subject. Minneapolis:

Minnesota University Press

Kaye, N. (2007): Multi-media: Video Installation Performance. New York: Routledge

Krauss, R. (1990): “A Note on Photography and the Simulacral", en SQUIERS, C. (ed). The Critical Image: Essays on Contemporary

Photography. London: Lawrence \& Wishart

Martínez Muñoz, A. (2000): De Andy Warhol a Cindy Sherman. Arte del Siglo XX-2. Valencia: Universidad Politécnica de Valencia

Pittas, M., Brody, D. y González, M. (1996): “Cindy Sherman en el Palacio Velázquez. Imágenes de Asco, Sexo y Horror”. Lápiz. No 12. Abril 1996. p. 74

Pultz, J. (2003): La Fotografia y El Cuerpo. Madrid: Akal

Turner, V. (1986): The Antropology of Perfomance. New York: PAJ Publication.

Vergine, L. (2000): Body Art and Performance: The Body As Language. Milan: Skira Editore S.p.A.

VV.AA. (1997: Cindy Sherman. Retrospective. London: Thames \& Hudson

VV.AA. (2008): Mujeres artistas de los Siglos XX y XXI. Madrid: Taschen. 


\section{3 \\ Exhibición actual de las prácticas artísticas en vídeo}

Francisco José Gómez Díaz, Universidad Complutense de Madrid

\section{Consideraciones previas}

— L concepto "videoarte" podría definirse como práctica en la que 1 se utilizan medios electrónicos analógicos o digitales con el objeto de crear una pieza con un valor artístico. Se podría considerar que el término está obsoleto y cabría referirse a prácticas artísticas en vídeo, ya que hasta la década de los 80 se denominó videoarte a los vídeos de creación más o menos experimentales, que no seguían unas reglas establecidas por el cine y la televisión, pero que perseguían valores expresivos o artísticos. Ahora, el vídeo abarca y se emplea de una forma más extensa, por lo que denominar a estas prácticas como videoarte puede crear confusión y delimitar demasiado su nivel de uso. Además, cabría plantear la siguiente cuestión: ¿qué se podría considerar videoarte y qué no lo es? En consecuencia, a través de la definición de prácticas artísticas en vídeo se podrían incluir todas las prácticas que tengan un fin expresivo u estético y que utilicen el vídeo como parte del desarrollo creativo o como soporte.

\section{Antecedentes}

El término salón, a mediados del siglo XVII, designaba el espacio expositivo y, la denominada "Academia," era la que se reservaba el derecho de admisión de las obras. Esta situación, desde sus orígenes, 
produjo una reacción de rechazo por parte de los artistas contra las instituciones artísticas oficiales que no reconocían su trabajo como arte. Esta fricción se extiende hasta la actualidad y aún los artistas audiovisuales no se ven reconocidos por parte de las instituciones oficiales o las propias instituciones no los reconocen como productores de arte.

\section{Artistas de vídeo y museos}

La necesidad expositiva no es un fenómeno aislado ni nuevo. Ya en los años 20-30, el movimiento Bauhaus pretendía sacar el arte a las calle, fuera del museo. En los 60, el grupo Fluxus quería romper con los códigos establecidos y desvincularse de las formas convencionales de exhibición manteniendo algunas de las premisas impulsadas por el movimiento Bauhaus. Además, durante estos años, se produce un suceso clave: el tránsito de la fotografía al vídeo. Ambos soporten conviven, no se sustituyen y se mantienen hasta la actualidad y se produce una coexistencia, pero el vídeo asumió de forma diferente el ritmo tecnológico de los tiempos.

La introducción del vídeo como práctica artística data de la segunda mitad de los 60 formando parte de los considerados nuevos medios. El vídeo, como tal, representaba la incorporación de la tecnología más avanzada. Las primeras apariciones de monitores con vídeo correspondieron al grupo Fluxus, que defendía la eliminación de la obra de arte como mera mercancía negando al objeto artístico tradicional mediante la conversión en prácticas artísticas a través de cosas, aparentemente, banales pero con una gran carga expresiva. Nam June Paik o Wolf Vostell formaron parte activa de Fluxus y dentro de las prácticas artísticas en vídeo cabe destacar sus aspectos formales: la primera tomando el vídeo como experimentación electrónica, como fue el caso de Paik y, la segunda, utilizando el vídeo como documento de un acontecimiento artístico efímero como, por ejemplo, la grabación de happenings por Vostell.

El denominado "videoarte de los 80 " pretendía lo mismo y aunque se institucionalizó, en la actualidad, forma parte de cualquier archivo que se precie de un museo de arte contemporáneo. Siguiendo la línea del tiempo, surge el net-art en los 90 y lleva el concepto de 
desvinculación al máximo exponente, al convertir la red en su hábitat de desarrollo y exhibición. Por lo que las prácticas artísticas en vídeo, durante estas décadas y hasta los 90, ya se trate de video-esculturas, happenings, body-art, etc., se grababan en vídeo para proteger la permeabilidad de los mismos y salvar las obras de la destrucción y, a pesar de conseguir una calidad deficiente, lo que interesaba era la forma, a diferencia de las prácticas en vídeo actuales en la que puede primar la forma y la tecnología o una u otra, de forma independiente, como puede ocurrir en la infografía.

\section{Vídeo y televisión}

Wolf Vostell se declaró enemigo de la televisión y en sus creaciones critica a este medio de una forma directa y voraz pero, además, de Vostell son muchos los artistas que utilizan el vídeo en sus prácticas y que rechazan a la televisión y utilizan sus obras como denuncia hacia sus contenidos, al lenguaje y los posibles efectos negativos que produce este medio. Artistas españoles como Antoni Muntadas o Francesc Torres, entre otros, critican a la televisión a través de su obra.

"Con la televisión el videoarte mantiene una compleja relación de amor-odio. Por una parte comparte su misma base tecnológica y gran parte de sus herramientas; por otro, rechaza su papel mediatizador y alienador como medio hegemónico de comunicación de masas, su papel político como factoría de conciencias al servicio de los poderes sociales, su iconografía, su lenguaje..." (Irarzo, 2011).

Haciendo un breve repaso de la relación del vídeo y la televisión, en los años 80, cabe destacar que se produjeron movimientos en Estados Unidos y más tarde en Europa de artistas que pretendían hacer su propia revolución desde dentro, con su consecuente acercamiento de estos artistas al medio televisivo. En España, RTVE produjo la serie "El Arte del Vídeo" en 1990, década en la que la relación artistamedio se disolvió por varias razones de las que cabe destacar la aparición de una gran cantidad de canales de televisión, que produce una gran competencia para conseguir audiencia y una lucha para aportar valor comunicativo a los anunciantes, ya que la publicidad era 
la principal fuente de ingresos para las cadenas y, a esta razón, se une al desencanto de los artistas y a la aparición de nuevas tecnologías que provocan un cambio, tanto de paradigma estético como en la forma de exhibición de la obra. En la actualidad, se producen algunas excepciones en la relación entre el vídeo y la televisión y se incluyen este tipo de prácticas artísticas en canales especializados como el canal francés Arte o, como en el caso español, en el programa Metrópolis (el programa de cultura contemporánea de La2 de TVE, con casi 30 años de trayectoria).

Como conclusión de por qué la televisión no ha servido de plataforma para este tipo de prácticas en vídeo cabe destacar dos razones: por el tipo de contenido y por el destinatario. La TV no apuesta por el riesgo en su programación, las prácticas artísticas en vídeo llevan implícitas el riesgo, ya que rompen con el lenguaje audiovisual institucionalizado por el cine y la TV, apuestan por la experimentación como forma expresión y la ruptura de los códigos visuales y no se someten a fórmulas mágicas de éxito.

\section{Funciones del museo para el vídeo}

Si el vídeo ha evolucionado en sus prácticas y formas de exhibición, cabe reflexionar e intentar definir qué es el museo en la actualidad, cómo podría definirse y cuál es el papel que desempeña en sí mismo y su actual relación con el vídeo.

\section{Para Rafael Gómez Alonso}

"El museo se entiende en la actualidad como un fomento de marketing. (...) Se pretende transmitir la idea de construir un lugar de todos los tiempos, en donde se entrecrucen planteamientos del museo junto a nuevos espacios que interpelan al mundo de las nuevas tecnologías multimedia, pero también se concibe una idea de auto-referencialidad de los museos" (Gómez, 2003). Además, Gómez Alonso destaca que "se puede llegar a interpretar que los proyectos e intereses de los museos se encuentran en un período de transición en donde todavía no se sabe muy bien cuales son sus propuestas, pero lo que sí queda claro es que sus objetivos ya no son, únicamente, 
el público culto, minoritario, intelectual, con cualidades" (Gómez, 2003).

Desde un punto de vista centrado en el soporte del vídeo y en su vertiente comercial, Arantxa Lauzirika explica que "Cuando se comienza a trabajar con el vídeo de una forma experimental, sin una intencionalidad comercial, a medida que los que trabajan en este contexto empiezan a tomar relevancia en el panorama artístico y se le da importancia a su producción, el entramado del arte absorbe estos trabajos y tiene la necesidad de cosificarlos y objetualizarlos para ponerlos en el mercado" (Lauzirika, 2010).

En las prácticas artísticas en vídeo, con frecuencia, desde su aparición, suele haber un rechazo de los artistas a las formas institucionalizadas de exhibición, aunque por otra parte, se podría decir, que los artistas más reconocidos (como, por ejemplo, Bill Viola) terminan por vincularse tanto al museo como a las galerías de arte, ya que es allí donde encuentran, además de refugio, solvencia económica, reconocimiento y la posibilidad de exponer sus obras de una forma más sofisticada y espectacular.

La incorporación de prácticas artísticas en vídeo a los museos y galerías de arte sirvieron de canal y forma de exhibición de estas prácticas artísticas y proporcionaron, en cierto modo, al vídeo un valor artístico, además, es evidente que su exhibición en museos y galerías contribuyó a su supervivencia (en la actualidad, ciertas instituciones incluso se podría considerar que funcionan como archivo), a pesar de la reacción de muchos artistas que lo veían como contradictorio ya que en muchos de los casos el vídeo era una reacción contra la institucionalización del arte.

La incorporación del vídeo a estos circuitos de exhibición, si se compara con la fotografía se produjo relativamente pronto, en apenas décadas, pero es aún más vertiginosa sus otras vertientes como el netart y la infografía que lo han hecho en apenas una.

La incorporación del vídeo al museo u otro tipo de instituciones artísticas, además de servir para confirmar su naturaleza artística, produce un triángulo (Artista-Público-Institución) que se podría 
considerar positivo en ciertos aspectos: El artista muestra su creación, la exhibe y la institución reconoce su obra. Además, el público es capaz de disfrutar de la obra dentro de la institución y de comprenderla, al encontrar información adicional del artista y de la obra en sí, pero este último vértice del triángulo es relativo porque otros medios podrían proporcionar esa información y, en el caso de Internet, se podría ampliar la misma, así como incorporar links a obras similares enriqueciendo la experiencia del usuario y siendo capaz incluso, de relacionarlas con otras obras similares u opuestas. Por su parte, la institución se enriquece respecto a nuevos formatos y exhibe otro tipo de contenidos en otros soportes, respecto a los reconocidos como convencionales.

\section{La red en la actualidad}

La red hoy en día es una forma asequible y accesible para los artistas que deciden exponer su obra de una forma alternativa al museo convencional. "Muchos artistas habían visto en Internet la posibilidad de disolver el concepto arte en el más general de comunicación, tratando de escapar de las predeterminaciones de los contextos expositivos institucionales y de la cierta prealineación del sentido de lo creado dentro de los parámetros de los artístico" (Prada, 2012).

Maite Ninou es bastante contundente en su postura sobre los museos y su visión de futuro sobre ellos y expone que "Internet ha permitido que grupos de música lleguen a ser conocidos masivamente, sin discográfica ni marketing detrás, y que vivan de su música. Ahora son unas decenas los artistas que se dan a conocer y no son sólo cuatro nombres famosos y millonarios. Supongo que esta situación se trasladará al mundo del vídeo y hará que las galerías tengan aún menos sentido" (Ninou , 2010).

Blanca Montalvo opina que "el museo como lo entendemos hoy, el conjunto inseparable del lugar físico, edificio de las obras y su organización, colecciones, de las funciones desarrolladas por la institución, didácticas, promocionales, científicas, y de su papel social, surge a partir de la mitad del siglo XVIII, en relación directa con la afirmación y difusión de la cultura ilustrada. Su origen se centra en la reunión de curiosidades mediante financiación privada. Las crisis 
económicas, si bien o no deseables, puede que limpien el panorama actual de la paja que lo inunda, apostando por contenidos y propuestas culturales independientes de labores políticas y promociones publicitarias vacías e irreflexivas" (Montalvo, 2011).

Isidro Moreno, muestra otro punto de vista y responde a la pregunta: ¿Qué plataforma es la idónea para las prácticas en vídeo?

"Lo primero que hay que subrayar es que la difusión de la videocreación debe ser transmedia, es decir sumar, en lugar de restar y jugar a los opuestos. Dicho esto, hay que pensar en el tipo de creación. Una videocreación que persiga la mayor inmersión, la multipantalla, la imbricación con otros elementos... debe utilizar un espacio real: el museo, la calle, una estación... Para el resto, Internet es su lugar natural y las pantallas fijas del hogar, las tabletas, los smartphones... los terminales de acceso. Este tipo de producciones también es interesante que estén en los archivos digitales del museo y puedan exponerse en él mismo o acceder a ellas, si es que el autor no permite su difusión masiva y gratuita" (Moreno, 2012).

Ana Sedeño Valderós apunta que "En adelante, las nuevas fórmulas de la creación videoartística se desarrollarán en torno a algunas ideas, procesos o fórmulas" (Sedeño, 2011) y destaca algunas de las ideas propulsadas por el colectivo sevillano Zemos 98 como que la investigación sobre políticas culturales para dar lugar a nuevas formas de participación ciudadana y emprendizaje cultural que darán nuevas dimensiones a las galerías, los museos, las instituciones culturales, etc. La experimentación en nuevos lenguajes y narrativas audiovisuales y digitales, desde la experiencia sonora a la cultura VJ y los narrative media, el cine interactivo y fragmentario, la cibercultura, los media y el desarrollo de la cultura libre, donde conceptos como apropiación de imágenes, archivo y remezcla serán centrales como fuente para nuevos contenidos y lenguajes.

Eva Lootz, artista veterana que incluye entre sus prácticas artísticas el vídeo comenta: 
"Tanto la red como el museo cumplen cada uno su papel, el museo porque tiene los medios y los espacios para hacer una presentación óptima de los videos en cuestión, multiproyecciones, proyecciones en el techo, en el suelo etc, puede adecuar la obra al espacio. En una palabra, hacer que el/los video/s se conviertan en una experiencia sensorial completa e impactante. Un video de Bill Viola no es para verlo en Youtube..." (Lootz, 2012).

Cristina Cámara, del Museo Reina Sofía, apunta: "El vídeo ha pasado de ser un medio "marginal" que se mostraba únicamente en los auditorios o en salas de exposición temporales a estar integrado y normalizado en el recorrido de las colecciones permanentes y en los programas culturales de los museos". Cuando se le pregunta sobre el museo como archivo, Cámara, especifica que el uso del término archivo "conlleva una reflexión sobre su acepción" y concreta:

"Las mismas colecciones pueden considerarse archivos así como los contenidos de las bibliotecas y centros de documentación de los museos, con sus materiales audiovisuales. Creo que con la normalización del medio en los museos, el vídeo deja de tener importancia como medio para tenerla por su carga artística. Por lo tanto, el vídeo está presente como cualquier obra en otros formatos" (Cámara, 2012).

Eli Lloveras, de la plataforma de distribución española HAMACA, habla de la función de HAMACA respecto al vídeo y de los diferentes canales expositivos actuales:

"No creo que hayan unas formas expositivas correctas y otras que no lo sean siempre y cuando se respete el trabajo en sí. Actualmente el vídeo posee múltiples ventanas para ser mostrado y consumido y cada una de ellas ofrece diferentes experiencias al espectador y cumple a su vez con distintos objetivos" (...) "Una de las metas que hemos perseguido con HAMACA ha sido precisamente abrir el vídeo a nuevos públicos más allá de la institución y del mismo circuito artístico. Presunciones que parten del mercado del arte y que hace algunos años se tenían 
tipo "cuanto más se vea un vídeo menos valor tendrá" se han desvanecido con el tiempo. Y como prueba encontramos que la comunidad artística utiliza Internet como una ventana más para hacer su propia difusión de los vídeos a través de plataformas como el YouTube o Vimeo. HAMACA es una distribuidora independiente que se está haciendo cargo de tareas de preservación, archivado y difusión de un acervo formado actualmente por 800 vídeos representativos de su historia en el Estado español. La preservación del patrimonio artístico es algo que le corresponde al museo. Hay que pensar que HAMACA es un archivo donde se pueden consultar los videos $y$ hay información textual y teórica sobre ese tipo de producción, ese es uno de los valores añadido que da HAMACA. Desde HAMACA hemos intentado acercar la idea de que colgar los videos online para que se puedan visualizar es bueno y es el lugar óptimo donde comunicar lo que haces (entendemos que para mucha gente no sea el lugar más adecuado donde verlo, pero sí donde comunicarlo). Evidentemente, la elección final es del artista, que es quien debe elegir dónde, cómo y con qué objetivo mostrar su trabajo". (Lloveras, 2012).

\section{Plataformas online como forma de exhibición: Caso Vimeo}

Muchos artistas apuestan por mostrar su obra directamente en su página web o en plataformas como Vimeo, que es una plataforma online creada por un grupo de amigos, que en su origen, se desarrolló como una necesidad personal de albergar vídeos personales y terminó en convertirse en una plataforma para cineastas y videoartistas para que muestren sus obras y compartan sus trabajos creativos con otros miembros. La plataforma permite crear grupos en torno al cine y el vídeo. Según datos facilitados por Vimeo en su web, la plataforma cuenta con más de 22 millones de usuarios registrados y se le podría definir como una de las plataformas más interesantes de exhibición de vídeos en la red. Además, se les considera una comunidad de creadores que trabajan en red, que opinan sobre sus creatividades e intercambian experiencia y conocimiento técnico.

Vimeo no es una plataforma tan masificada como YouTube, ni tampoco persigue ese interés. Los fundadores apuestan por la calidad 
y la especialización, como rasgo diferenciador y, dentro de la plataforma, tienen cabida creativos, directores, realizadores, guionistas y un sinfín de artistas que utilizan el vídeo y que comparten inquietudes e intereses similares sobre este soporte para realizar sus prácticas artísticas. El diseño es más sencillo y más limpio que otras plataformas y dispone de una interfaz muy intuitiva. Se podría considerar que Vimeo cumple las características de Web 2.0 (a pesar de que Tim O'Reilly, defensor de este término, lo considere una definición obsoleta) ya que permite compartir información, promueve la interoperabilidad, el diseño, está pensada para el usuario y la colaboración es la máxima de su filosofía y su visión. Vimeo propone y permite a sus usuarios interactuar y colaborar entre sí como creadores de contenido (vídeos) generado por usuarios en una comunidad virtual. Cabe destacar que los vídeos alojados son, en su totalidad, creados por los usuarios, se produce una participación directa de los mismos en el proceso creativo del vídeo y, respecto al formato, se apuesta por la alta definición (HD), que Vimeo incorpora bastante antes que otras plataformas de vídeo online y que más tarde han adoptado, tanto por demanda de los usuarios como por necesidad tecnológica actual.

\section{Características que convierten a Vimeo en una plataforma de exhibición aceptable para las prácticas artísticas en vídeo}

Vimeo permite la creación de grupos y la adhesión a otros grupos, por lo que el creador puede relacionarse con creadores de prácticas similares. La calidad es una máxima en Vimeo y la presión de subir un vídeo de calidad, se la ejercen los propios usuarios a sí mismos, "no todo vale". La plataforma proporciona facilidad de visionado y herramientas útiles para subir vídeos con códecs de compresión que mantienen una excelente calidad de las creatividades alojadas en la plataforma. Además, permite la convergencia con otras plataformas y webs, lo que ofrece a los usuarios versatilidad y permite que sus vídeos se visionen desde otras plataformas en las que se incrusten y permiten la viralidad, ya que otros usuarios pueden referenciar los videos en otras comunidades.

Respecto a las estadísticas, la plataforma ofrece datos específicos de los vídeos: si las piezas se han visto en su totalidad o sólo en parte y 
cuántas veces, número de descargas, en qué se país se han realizado las visitas y si se han visto desde Vimeo o han sido incrustados en otras web. Además, a parte de los consejos facilitados entre usuarios, la plataforma dispone de vídeos, a modo de clases prácticas, a través de Vimeo Vídeo School de la mano de profesionales reconocidos del sector audiovisual como, por ejemplo, Phillip Bloom y, de esta forma, la plataforma proporciona formación a las personas que quieran mejorar sus conocimientos técnicos.

\section{Creative Commons}

Los Creative Commons se están extendiendo, cada vez más, entre artistas que utilizan el vídeo en sus prácticas ya que conceden a los usuarios permisos de derechos de autor en sus vídeos para que otros puedan copiar, distribuir, editar, mezclar, y construir sobre ellos, mientras se reconozca en los créditos al creador del video original. Proteger las obras bajo una licencia de Creative Commons no supone que no tengan copyright. Este tipo de licencias proporcionan algunos derechos a terceras personas pero bajo determinadas condiciones.

La posibilidad de poder manipular textos sin el uso del papel, el acceso a fotografías, sonido y vídeos es posible desde cualquier punto del planeta que disponga de un dispositivo de acceso y conexión a Internet. Se relacionan conocimiento e intercambio, datos, nuevas formas de negocio y entretenimiento, esto se puede conectar directamente con el arte, con lo que está sucediendo en las prácticas artísticas con vídeo.

María Cañas es una creadora que tiene una vision clara de las plataformas online y de los derechos que protegen a los artistas y comparte su experiencia personal: "Apuesto por los Creative Commons. Internet permite llegar a grandes audiencias gracias a las licencias. SGAE, es un cáncer condenado a desaparecer. Su ética, credibilidad y practicidad son nulas. No pertenezco a ninguna entidad de gestión de derechos de autor. Mis vídeos pueden verse gratis en Internet en la distribuidora Hamaca, Blogs\&Docs, Cámara Excéntrica, Youtube, vídeoblogs.... Creo que el arte ha de ser viral, expandirse y comunicar. Mis trabajos no tienen cabida dentro de los circuitos de estrenos en las salas comerciales, son videomaquias, 
visiones del mundo heterodoxas, diferentes a las que la industria de la televisión y el cine nos lanzan. Cuando el audiovisual es entendido como un espacio ilimitado dónde experimentar, cuestionar y transgredir, sólo encuentra su sitio en Internet, museos, festivales, bares y espacios alternativos. La filosofía del "hazlo tú mismo", la autogestión, la economía del trueque y la cultura libre del reciclaje y la remezcla, expandidas por Internet, han convertido el arte para las masas en el arte que hacen las masas. Es una cultura mucho más participativa pero no por ello siempre de mayor calidad" (Cañas, 2012).

En su obra El perfecto cerdo (2005) Cañas intentaba confrontar esa creencia popular de que del cerdo se aprovecha todo con el modus operandi de numerosos creadores para los que su obra se basa en la apropiación y la libre circulación de la información por internet y mantiene la creencia de que a la hora de crear en la actualidad "si del cerdo se puede aprovechar todo, de la imagen contemporánea y del detritus audiovisual que nos rodea igual" (Cañas, 2012).

El interés de Cañas conecta con "la creación generada por todos esos artivistas anónimos o francotiradores que cuelgan sus fotomontajes y vídeos en internet, que la realizada con grandes medios por artistas mainstream". Cañas (2012) y de sus declaraciones se pueden extraer varias cuestiones cruciales en el panorama que ocupan las prácticas artísticas en vídeo en la actualidad: la problemática y lo que podría suponer una reformulación de la propiedad intelectual y los márgenes sociales para la estipulación de una cultura más libre, accesible a todos y participativa. "En este sentido, la generalización del software libre, el movimiento Copyleft, las licencias libres para la creación o la articulación de dispositivos abiertos de conocimiento en la Red, son elementos esenciales en el medio educativo y artístico digital, y su evolución conformará nuestro tiempo" (Cañas, 2012).

Ya ha habido varios intentos de regulación de estos derechos, como ocurrió en 1998 en CISAC (Confederación de Sociedades de Autores y Compositores de París en que se presentó el CIS (Sistema de Información Común), con el que se pretendía que no circulase en la red ningún dato sin identificar, evidentemente, este ha sido, otro de 
muchos intentos, de mantener el control. Pero parece ser que el problema persiste y exige otra definición y revisión.

Castells en "La Sociedad Red" llega a unas interesantes conclusiones, que se podrían extrapolar a este paradigma y explica que, como tendencia histórica, las funciones y los procesos dominantes en la era de la información, cada vez, se organizan más en torno a redes y explica que "El trabajo pierde su identidad colectiva, individualiza cada vez sus capacidades, sus condiciones laborales y sus intereses y proyectos. Quiénes son los propietarios, quiénes los productores, quiénes los gestores y quiénes los servidores se vuelve cada vez más difuso en un sistema de producción de geografía variable de trabajo en equipo, de interconexión..." (Castels, 2010).

\section{Evolución de la tecnología en vídeo. Actualidad}

La tecnología ofrece a los artistas audiovisuales nuevas posibilidades formales y expresivas, que se extienden también al ámbito de difusión y exhibición de la obra. Además de los propios museos y galerías de arte, la televisión e Internet son medios a través de los cuales los artistas pueden ofrecer sus obras y los espectadores/usuarios/consumidores las reciben/disfrutan. De esta forma, tanto artistas como usuarios pueden evitan los circuitos expositivos tradicionales y esto, a su vez, ha provocado que se generen nuevas formas de experiencia artística.

Estos canales permiten al artista llegar a un número infinito o indeterminado de usuarios o consumidores de arte y desarrollar otras formas de consumo fuera de las instituciones, como podría ser el consumo individual en el hogar, dentro de la propia intimidad del consumidor de este tipo de arte en soporte de vídeo. Estas prácticas provocan una percepción artística diferente que puede llegar a crear otro tipo de sensaciones; hay obras que permiten una mayor interactividad y formar, de alguna manera, parte de ella (cambiar el final, la trama, participar en la obra añadiendo o quitando elementos u obtener información extra así como la posibilidad de visionar obras relacionadas) se plantea entonces la pregunta si existe una necesidad real de consumo in situ y de exhibir la obra en instituciones 
tradicionales, normalmente de la mano de instituciones artísticas respaldadas por otras de índole económica, social y/o política.

El vídeo incorpora tecnología que posibilita a los artistas, usuarios de este soporte, evolucionar y abrir nuevas puertas a la experimentación llegando al punto en el que los límites, entre la tecnología y la experimentación, son cada vez más infinitos. Ahora con un portátil se pueden conseguir resultados inimaginables por una productora hace tan sólo 10 años. La incorporación de la infografía abre puertas a nuevos conceptos y lenguajes, siendo aún experimental y cambiante, de una forma constante y frenética se enfrenta a la misma situación a la que se enfrentó en su tiempo el cine, la fotografía y el vídeo, a diferencia de que el vídeo consiguió institucionalizarse como práctica artística en menos de dos décadas y la infografía lo está haciendo en apenas una.

"Las tecnologías surgidas desde mediados de los 90 han recuperado el espíritu de mediados de los 60 (o de principios de los setenta en España), que reavivan algunas de las ideas de los conceptual, pero trasladadas a otro contexto. Vuelve a haber un interés por la información, por la divulgación de la información. Muchas obras que abordan aspectos relacionados con la colectividad, las redes sociales..." (Mercader, 2010).

En la actualidad, el mundo de la creación en vídeo es imposible de delimitar y en él conviven prácticas rudimentarias con tecnología punta y experimentación tecnológica, por lo que convive el concepto de lo real con lo irreal y se produce una ruptura del espacio y del tiempo. La imagen digital ha cambiado en apenas tres décadas y es una de las aportaciones más importantes de la iconografía actual.

Lo digital implica nuevas posibilidades y experimentación, ahorro de costes de producción, un acceso más universal a la tecnología y la posibilidad de la infinita repetición (se elimina el miedo al coste de producción de la experimentación dado su gratuidad). Se podría llegar a hablar de cultura digital ya que forma parte de la cultura contemporánea, lo digital es algo cotidiano, ya no podemos hablar de nuevas tecnologías sino de tecnologías sin más, lo digital se ha implantado de forma asombrosa sustituyendo en gran medida a la 
tecnología analógica, que aún convive y se utiliza en ciertas prácticas, pero es utilizada con un interés expresivo, con tono decadente, revival o vintage.

Los avances tecnológicos provocan la evolución de los sistemas de representación visual y se produce la tecnologización de la imagen. La tecnología no sólo crea dispositivos de producción sino que también se convierte en creadora de modelos sociales y artísticos. Se podría llegar a decir que el ordenador, en la actualidad, funciona como un apéndice ejecutor de las órdenes del artista, pero se llega a crear una simbiosis, en las que las nuevas necesidades creativas del artista se cubren con la tecnología y las nuevas posibilidades que proporciona la tecnología hacen que el artista genere nuevas imágenes y códigos.

Las tecnologías de la información y la convergencia de los medios hacia lo digital, han tenido un impacto considerable en la producción artística en vídeo, pero también en la difusión y el consumo, así como la creación de nuevas formas de expresión en vídeo como códigos. Todo esto, propiciado por las tecnologías de la información y condicionadas por las nuevas formas de exhibición generadas en la red.

Se podría llegar a decir que las nuevas formas de producción digital quizás no corresponden a una evolución natural de la producción de imágenes y sonidos, sino que hay un salto cuantitativo y cualitativo, lo que ha producido un cambio de lenguaje visual vertiginoso que no se puede comparar a otros movimientos artísticos que surgen de la evolución o de la ruptura, pero que transformaron el concepto, no las prácticas en sí ni los materiales. Las tecnologías aplicadas a lo audiovisual evolucionan de forma frenética y es casi imposible mantenerse a la última ya que requiere de un constante reciclaje y experimentación.

Josu Rekalde habla de que el movimiento de las prácticas artísticas en vídeo quizás sea "el último impulso que parte de las vanguardias artísticas" y que la tecnología digital podría suponer una revolución para los medios situando al arte en una posición difícil de ubicar en la que la distribución es inmediata, sin intermediación y donde la creación se convierte en colectiva y añade "las estructuras artísticas 
siguen ancladas en el objeto estético encerrado entre paredes y resguardado por guardas de seguridad y altas pólizas de seguros. La idea de la modernidad en la que el arte podía transformar el mundo ha girado 360 grados hacia la realidad y es el mundo el que estás transformando el arte. El arte sigue siendo un fenómeno de adaptación cultural al medio que nos toca vivir y ahora el medio es conectividad en red. Un medio que nos lanza de nuevo hacia su propia publicidad y propaganda, hacia su nueva definición de mass media ¿cabe reaccionar desde el arte?: NET IS NOT INTERNET" (Rekalde, 2010).

\section{Conclusiones}

Desde su origen hasta la actualidad, las prácticas artísticas en vídeo se han enfrentado al problema de la exhibición y encontraron, en algunos de los casos, su refugio en el museo, que con el tiempo las aceptó y reconoció como prácticas con valor artístico. Además, la aceptación del soporte vídeo, con carácter artístico, se ha producido en un tiempo relativamente breve, si se compara con algunos de sus predecesores, como podría ser la fotografía, que tardó décadas en ser reconocida como una práctica artística.

A lo largo del desarrollo del vídeo, muchos de los artistas que utilizaron este soporte, se opusieron a las instituciones y buscaron otras formas expositivas. La televisión, en su evolución como medio, salvo excepciones puntuales, no las ha incorporado en su programación, por tratarse de un contenido de riesgo o, simplemente, porque no encajaba como contenido de interés masivo, por lo que podríamos decir que la televisión no ha servido de plataforma para este tipo de prácticas en vídeo. Estudiando la evolución que ha tenido el vídeo en su incorporación y uso, con fines artísticos, se podría llegar a la conclusión de que el museo, por el contrario sí que ha servido como canal expositivo, incluso ha conseguido constituirse como archivo de muchas obras que, de otra forma, hubieran desaparecido.

En la actualidad, sigue funcionando y proporciona a estas prácticas un valor añadido en el visionado (pantallas de grandes dimensiones, sonido envolvente, salas equipadas especialmente para su exhibición) 
pero bien es cierto, que no pueden/quieren acoger todas las prácticas que se realizan en la actualidad, ya sea por su interés, reconocimiento artístico o su capacidad de generar ingresos, por lo que muchas de esas prácticas, con el surgimiento de la red han encontrado plataformas en las que ser exhibidas y los artistas han conseguido alojar sus obras en ellas, en muchos de los casos, con una independencia total de los museos.

Respecto a la tecnología, nos encontramos que en su evolución, además de proporcionar al artista herramientas de creación también le ha ofrecido un soporte expositivo en las diferentes plataformas que permiten albergar vídeos en Internet. Ambos factores, junto con la democratización de la misma, han provocado un resurgir de las prácticas artísticas en vídeo, o al menos una mayor visibilidad.

"La aparición de tecnologías mediales "do it yourself", quasi domésticas, que permiten la producción táctica de pequeños dispositivos micromediales (en la red Internet, pero también en el ámbito de los «viejos media», tipo radio, revista o televisión) asegura una transformación profunda del espacio de las tecnologías de distribución pública del conocimiento y las prácticas artísticas” (Brea, 2002).

La red como canal de exhibición junto con el amplio conocimiento técnico de muchos de los creadores, sumado a la posibilidad de enriquecimiento que proporcionan las comunidades, son factores que permiten a los artistas que desarrollen prácticas de gran calidad y, por otra parte, la acogida de los Creative Commons ha permitido que se produzca un nuevo concepto de artista, que basa su creación en la manipulación, apropiación, edición y mezcla de otras obras creadas por otros, generando, de esta forma una "creación de creación" asumida y reconocida como práctica artística.

También cabe referirse a la convergencia de los medios y los dispositivos tecnológicos que permiten que el museo y la red se complementen y enriquezcan. Por consecuente, cabría la posibilidad de estudiar nuevas vías con el fin de encontrar el equilibrio y esa cohesión y, más aún, cuando uno de los objetivos de los museos debería ser el poder dar a conocer al público general todas las 
manifestaciones artísticas que se produzcan dentro de la sociedad. Pero, por otra parte, bien es cierto, que en muchos casos, son los propios artistas los que rechazan a las instituciones, lo que provoca el riesgo de que esos movimientos artísticos que surgen lleguen a desaparecer sin que un público menos vinculados a ellos, pero no menos interesado, se quede sin disfrutar de esas prácticas artísticas.

Por último, aparte de la desvinculación de los artistas, también afecta a la consolidación de las prácticas el tremendo desarrollo tecnológico que se está produciendo en nuestros días y que convierte en fugaces a esos movimientos con una gran base tecnológica, ya que cuando los artistas adoptan una tecnología surge otra y así sucesivamente.

\section{Referencias bibliográficas}

-Brea, J.L. (2002): La era postmedia. Acción comunicativa, prácticas (pos)artísticas y dispositivos neomediales. Salamanca: Consorcio Salamanca. -Carrillo, Jesús. (2004): Arte en la red. Madrid: Ensayos Arte Cátedra. -Castells, Manuel. (2000): La sociedad Red. Madrid: Alianza Editorial. -Gómez Alonso, Rafael (2003). "El museo: espacio creativo". En Icono 14, Volumen 1, número 2. Madrid, página 17; recuperado el 12 de enero de 2015, de

http:// www.icono14.net/ojs/index.php/icono14/article/view/456/331 DOI: 10.7195/ri14

-Martín Prada, Juan. (2012): Prácticas artísticas e Internet en la época de las redes sociales. Madrid: Akal.

-Rodríguez, Fundación. VVAA. (2010): En torno a en torno al vídeo. Vitoria: Ayuntamiento de Vitoria.

-VVAA. Coordinadora Sedeño Valdellós, Ana. (2011): Historia y estética del videoarte en España. Zamora: Comunicación Social.

\section{Entrevistas personales}

-Cámara, Cristina. Museo Reina Sofía. Madrid. 28 marzo, 2012. -Cañas, María. Artista. Sevilla. 9 mayo, 2012

-Moreno, Isidro. Madrid. Universidad Complutense. 17 abril, 2012.

-Lootz, Eva. Artista. Madrid. 11 febrero, 2012

-Lloveras, Eli. Barcelona. Distribuidora HAMACA. 27 abril, 2012. 


\title{
El vídeo musical en el entorno de exhibición de las prácticas artísticas
}

\author{
Ricardo Roncero Palomar, Universidad Rey Juan Carlos. \\ Raquel Sardá Sánchez, Universidad Rey Juan Carlos
}

IS vídeos musicales son piezas audiovisuales que, desde su imaginario de la cultura juvenil. Los podríamos definir como "obras audiovisuales, de intención fundamentalmente promocional, ya sea de la banda/artista o del tema musical, de entre 3 ó 4 minutos de duración, en la que, por lo general, se presenta a una banda/artista interpretando el tema, a veces acompañada de imágenes con valor narrativo propio y otras, con un valor poético" (Roncero, 2008). Es está cualidad promocional la que ha hecho que estos vídeos estén en medio camino entre el anuncio publicitario y las piezas de vídeocreación. La versatilidad de este formato indica la riqueza formal del mismo. Su gran libertad estética, acotada en parte por su utilidad como herramienta promocional, hace que el videoclip pueda adaptarse a múltiples lenguajes audiovisuales, desde los orientados al mercado exclusivamente publicitario, a otros puramente experimentales o artísticos.

En cuanto se aleja la definición ortodoxa del videoclip fundamentada en bases promocionales, comienzan las distintas variables en torno a su naturaleza. Marsha Kinders relaciona las diferentes variedades del clip en función de la fuente de donde provenga: "Dependiendo de 
qué medio de comunicación leas, el vídeo musical es un nuevo medio que amplía las posibilidades únicas de la estética de vanguardia anteriormente restringidas al cine independiente y al videoarte, una nueva combinación de música e imágenes que redefine las relaciones audiovisuales en los medios de comunicación, un nuevo medio de marketing para discos y cintas que está salvando la industria de la música pop, o una nueva fuente de imágenes sadomasoquistas violentamente sexistas que infectan las mentes de nuestros hijos" (Kinder, 1984).

Desde los primeros experimentos con el órgano color, pasando por los cineastas Absolutos o la llegada de las culturas juveniles y las piezas de Kenneth Anger la vinculación entre música -popular o noarte e imagen en movimiento ha sido muy estrecha. Por ello no es de extrañar que desde finales de los sesenta muchos artistas se sintiesen atraídos por el mundo de la música pop y rock y realizaran piezas basadas o dirigidas al mundo de la música popular. Uno de los primeros ejemplos es el film de Andy Warhol The Velvet Underground and Nico (A Symphony of Sound) (1966), en el que el artista filma a la banda Velvet Underground durante sus ensayos, o en las piezas dirigidas por el sueco Peter Goldmann para promocionar los temas de los Beatles Strawberry Fields Forever (1967) y Penny Lane (1967).

Con la adopción de los nuevos medios por parte de los entornos de exhibición artísticos como museos, centros culturales o galerías el vídeo musical encontraría un nuevo entorno de exposición. Las preguntas que surgen son: ¿qué sucede cuando un producto audiovisual cambia a una vía de exhibición diferente para el que fue creado? ¿Se siguen percibiendo de manera similar? o ¿el nuevo medio condiciona esta percepción?.

Este tipo de exhibiciones tiene algunas características muy marcadas que hacen que la experiencia del visionado sea diferente a la habitual en televisión o cualquier otro medio de distribución habitual del videoclip: la selección de estos vídeos dentro de un programa se realiza en relación a su contenido visual y no al sonoro. No se retransmiten de forma masiva para ser visionados de forma individual. En estas vías, los espectadores que contemplan la pieza de 
manera colectiva son mucho menor en número. No se mantiene el tamaño de pantalla televisivo, generalmente se proyectan en pantallas de dimensiones similares a las de exhibición cinematográfica.

\section{De la televisión al museo}

El MoMA lleva realizando desde los años 80 una selección de vídeos musicales que son incluidos dentro de su sección audiovisual (Sisario, 2014). Algunos de estos títulos son Ashes to Ashes (1980), de David Bowie, realizado por David Mallet, o Hello Again (1984), del grupo The Cars y dirigido por Andy Warhol, Act III (1983) de John Sanborn y Dean Winkler para Philip Glass, Frankie Teardrop (1978), del dúo Suicide y realizado por Paul Dougherty y Walter Robinson, Total State Machine (1985), dirigido e interpretado por Test Dept o All is Full of Love (1999) dirigido por Chris Cunningham para Bjork.

El museo transforma el vídeo musical. Su faceta plástica sobrepasa en interés al aspecto promocional, que queda anulado. Al igual que ocurre con el cine, la crítica artística sólo considera estas obras como arte cuando son mostradas en un espacio expositivo vinculado con el arte, (Sichel, 2006).

Con esta perspectiva encontramos dos variables bajo las cuales el vídeo musical puede ser mostrado en un entorno museístico.

-La primera sería tomando el vídeo musical como obra de video creación y dentro de un conjunto de piezas que pueden no tener carácter audiovisual pero que muestran una misma idea o concepto.

-La otra se crean entorno al formato del vídeo musical; selecciones de vídeos que parten de curadores para mostrar y reconocer al formato su aportación plástica y/o social. Exposiciones y exhibiciones que se centran en exclusiva en el vídeo musical pero mostradas en entornos para los que a priori no fueron creados.

\section{El vídeo musical, como parte de una muestra}

El video musical puede integrarse dentro de una exhibición debido a la importancia del nombre de su director, su contenido social o de género o por los logros técnicos que presenta, por poner algunos ejemplos. En el caso de la exposición Blanca Li, te voy a enseñar a bailar 
que tuvo lugar en enero del 2008 en el Museo de Arte Contemporáneo de Castilla y León (MUSAC) el vídeo realizado por el director Michel Gondry Around the World (1997) para el dúo francés Daft Punk era proyectado sobre una gran pantalla, formando parte de las obras que allí se exhibían. El trabajo de la coreógrafa Blanca Li era fundamental en el desarrollo del vídeo, de manera que un producto destinado a promocionar una canción era expuesto en un museo por el valor añadido que le daba la coreografía diseñada por la artista que articulaba la exposición.

En La imagen sublime, la primera exposición que realizó el Museo Nacional de Arte Reina Sofía en el año 1987 se expuso un vídeo musical. Entre la colección de vídeo creaciones nacionales que se habían realizado entre los años 1970 y 1985 se exhibió la pieza Mata a tu viejo (1985) de El Indio Jose Mari y dirigido por Josu Zabala. En su reseña leemos: "En España no existe ninguna industria de clips musicales (...) Así las cosas, la práctica totalidad de la producción española de clips se mueve en los límites de una marginalidad en la que predominan las realizaciones de escaso presupuesto y en baja banda, que prácticamente imposibilita el pase televisivo." (Palacio, 1997), características de la pieza más propios de las obras de vídeo creación de la época que del vídeo musical dirigido a las masas y preparado para ser emitido por televisión.

El entorno expositivo donde es más fácil ver vídeos musicales lo encontramos dentro de las programaciones audiovisuales de los centros de arte. Dentro del MNCARS una de las muestras que más hincapié realizó entre aspectos visuales artísticos y sonoros fue Música-Vídeo-Música. La selección contenía una serie de piezas realizadas por artistas visuales vinculadas con música popular. De entre las 27 piezas seleccionadas solo 3 fueron vídeoclips, : Hidden Place (2001) de Inez van Lamsweerde, Vinoodh Matadin y M/M para un tema de Bjork, A Ribbon (2005), dirigido por Lauri Faggioni y Michel Gondry para el músico Devendra Banhart, y la pieza creada por Ara Peterson, para Black Dice, Treetops (2004). Tres piezas que se alejaban de los estándares del video musical convencional. El curador dejaba espacio para comentar esta intrusión de lo publicitario en el arte: 
"Se supone que en primer lugar los vídeos musicales deben ayudar a vender discos, y después, si acaso, atender al arte. En realidad el arte nunca formó parte de la ecuación originaria. Pero podía ocurrir que los grupos que procedían de medios artísticos eligieran a un artista para dirigir sus vídeos, y entonces producían algo que era mucho más que una herramienta de promoción, elevando el nivel de la invención y la sofisticación visuales. Es el caso de las colaboraciones de Sonic Youth con los artistas Tony Oursler y Richard Kern, y con los cineastas Todd Haynes y Harmony Korine, por poner un ejemplo. A partir de los años noventa la influencia de la música sobre los artistas jóvenes que trabajan con vídeo ha sido considerable. Para muchos, la música y el sonido son elementos centrales que impulsan su trabajo, cuando no el asunto mismo de la obra." Nickas (2005).

En el caso de la exposición Switch on the power, ruido y politicas musicales comisariado por Xabier Arakistain y realizada durante 2007 en el CAAM de Gran Canaria, el MARC de Vigo y en el C. C. Montehermoso de Vitoria-Gasteiz, es diferente. El vínculo entre las obras se encontraba tanto en relaciones con la industria musical como en estrategias performativas y estéticas más propias del mundo del arte. Entre los autores músicos y artistas visuales como Chica y Chico, Nina Hagen, Laurie Anderson, Siouxsie Sioux o Peaches.

Los Videomix son programas de vídeo creación y cine experimental que organiza el centro cultural madrileño La Casa Encendida. Entre algunos de estos programas volvemos a encontrar vídeos musicales mezclados con productos audiovisuales de distinta índole. Por ejemplo Poética de los hoteles, donde conviven piezas de artistas cómo Itziar Okariz o Matt Hulse con videoclips como Moving (1999), de Nick Gordon para el grupo Supergrass; Hotel Yorba (2001), dirigido por Anthony Ernest Garth para The White Stripes, y I Feel Like The Mother Of The World (2005), de Bryce Kass para Smog. Otros Videomix como los dedicados a los artistas Shahzia Sikander y Woof Wan-Bau incluyeron tanto obra personal como sus piezas vinculadas con otras facetas más publicitarias como algunos vídeos musicales. 


\section{Exhibiciones construidas en torno al vídeo musical}

Han sido varias las muestras que diversos centros de arte han dedicado al vídeo musical como formato capaz de presentar opciones plásticas y artísticas al margen de su función promocional.

Una de las primeras sería la titulada Art of Music Video: Ten Years After, realiza en el Long Beach Museum of Art del 1 al 29 de agosto de 1991. El propio curador destacaba en el catálogo los logros del videoclip por fomentar y mostrar nuevos lenguajes visuales frente a otros formatos: "Incorporando los elementos del cine experimental, el vídeo arte y la animación en un formato corto comercialmente viable, el vídeo musical fácilmente ha hecho más para popularizar y promover experimentos con la visualización y la narrativa que todo los esfuerzos anteriores combinados realizados por la comunidad artística." Nash (1991).

La muestra hacia un repaso por aquellos aspectos del vídeo musical más destacables, desde un punto de vista estético y social en programas como The MTV Decade, incluía una selección de las obras que ayudaron a formar el lenguaje de los videos musicales emitidos en los primeros años de la MTV, Music Video and the Politics of Dancing, construida en base a una selección de videos en función de su discurso político y social, 20th Century Musical Visions, donde se realiza un repaso a los antecedentes del vídeo musical como herramienta promocional, Notes from the Underground que se traduce en una selección de producciones de origen alternativo creados de espalda a las multinacionales y por último Artists' Advertisement Alternatives donde se analiza la relación y cooperación entre los nuevos artistas visuales y los músicos.

La exhibición muestra el vídeo musical como un formato extremadamente flexible que puede albergar distintos tipos de discurso y forma, desde aquellos con aspiraciones totalmente publicitarias y que logran hacer del interprete de la canción una estrella hasta aquellos denominados Antivídeos y que buscan otro tipo de asociaciones entre la banda icónica y la visual, con frecuencia apartados de los canales habituales de distribución como la televisión, y que pretenden profundizar en aspectos sociales minoritarios, 
experimentar con líneas estéticas más arriesgadas o hablar sobre el propio video musical y los límites que la imagen otorga a la música que acompaña.

En el 2003 el MoMA realizó una exhibición utilizando algunos de los videoclips que tenía dentro de su catálogo de audiovisuales. La muestra titulada Golden Oldies of Music Video ofrecía una selección de 35 vídeos realizados entre 1965 y 1985 y aunque dentro de la selección tenía un mayor peso aquellos vídeos con grandes logros estéticos también se proyectaron otros cuyo valor se encontraba en la repercusión social de los mismos, como Bohemian Rhapsody (1975) de la banda Queen y dirigido por Bruce Gowers, o Beat It (1983), realizado por Bob Giraldi para Michael Jackson.

Durante la celebración de Art Basel Miami en el 2006 tuvo lugar una sección titulada Open Air Cinema. Utilizando como tema central el vídeo musical se presentaron los siguientes programas: Retrospectiva de los mejores vídeos del dúo musical electrónica Yello, una selección de los mejores videoclips de la distribuidora de vídeo arte y medios interactivos Electronic Arts Intermix (EAI), Music Video Art que consistía en un programa de vídeos musicales realizados por artistas visuales, The Music Is You que selecciona piezas en las que la banda icónica tiene la misma importancia que la banda sonora y una retrospectiva con los trabajos más célebres de la banda The Residents.

En esta ocasión la muestra gira en aspectos menos conocidos del vídeo musical y su vinculación más estrecha con el arte. Comprobamos que no hay espacio para el sector más popular del videoclip. Las dos retrospectivas se centran en grupos que han sido especialmente populares por su punto de vista plástico y transgresor en el vídeo musical, mientras que las otras tres focalizan toda la atención en el terreno artístico, ya sea mediante una distribuidora de video arte o a través de dos selecciones que acotan el formato a experiencias artísticas y nada promocionales.

La exhibición Buen Rollo, Políticas de resistencia y culturas musicales, realizado en el Macba en 2002 contenía dos programas que abordaba esta dualidad del vídeo musical, Esto es MTV, Entre el consumo y La 
vanguardia e Imágenes crítica. Mientras el primero se centraba en aquellos vídeos que más repercusión habían tenido en la cadena MTV el segundo profundizaba en estrategias visuales mas marginales proyectando obras como Tunic (1990), de Sonic Youth, dirigido por Tony Oursler; German Song (1995), dirigido por la vídeo artista Sadie Benning para Julie Ruin; The Queen is Dead (1986), de la banda inglesa The Smith, dirigido por Derek Jarman y Talk About the Passion (1988), dirigido por Jem Cohen para la banda norteamericana REM. Con esta comparativa se profundizaba en el diálogo entre la televisión musical como herramienta de promoción y estandarte de la cultura de consumo y en la resistencia que muchas bandas realizaron mediante sus videoclips.

\section{Un caso particular, el DVD de Arquitectura Efímera}

Si hay un caso verdaderamente especial es el proyecto que el dúo musical Fangoria realizaron junto al MUSAC. Una excepción a todo lo planteado hasta ahora en el que desde un principio se utilizó el formato del vídeo musical como una plataforma con interés artístico al margen de una herramienta promocional para la televisión.

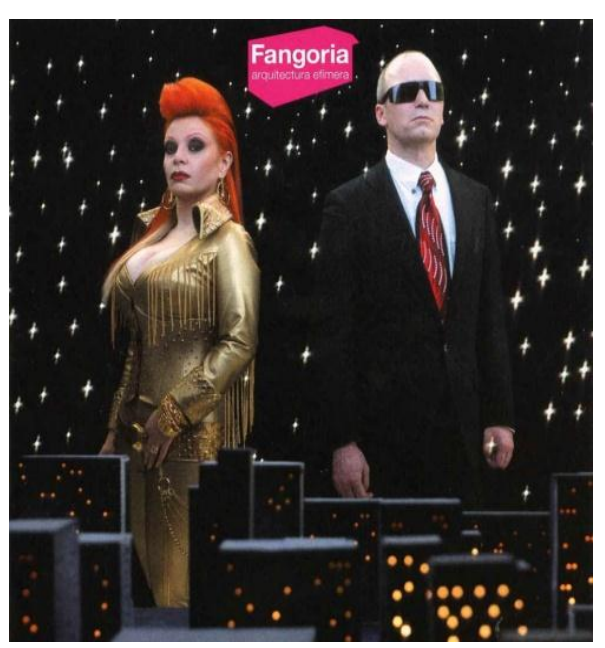

En el año 2004 el dúo de música electrónica Fangoria, compuesto por Nacho Canut y Olvido Gara publicaron su álbum número 14, titulado Arquitectura Efimera. Junto a la edición estándar se publicó otra especial, que incluía un DVD con seis videoclips que ilustraban algunas canciones de ese mismo álbum, realizados por otros tantos vídeo artistas. De las seis piezas, tan sólo dos acompañaron a singles y tan

Portada del disco Arquitectura efímera (2004) de Fangoria sólo una de ellas sufrió modificaciones de cara a su exhibición por televisión.

El proyecto se realizó en colaboración con el Museo de Arte Contemporáneo de Castilla y León, dirigido por Rafael Doctor. Estas piezas, comisionadas por el museo, pasaron a formar parte de su colección permanente. El director describía de esta manera como fue 
el proceso de elaboración: "Para este proyecto se le dio absoluta libertad a cada uno de los artistas, a excepción de Carles Congost al que se le encargó el videoclip del primer single del disco. Al resto no se les puso ninguna limitación más allá de la económica lógica. Para mí fue una sorpresa que al final eligieran todos el formato videoclip pues pensaba que se ceñirían a estructuras más libres y menos ajustadas a la música grabada."

Las piezas que componen la colección son de distintas facturas. Todas se ajustan al lenguaje personal de cada director, por lo que no es casualidad que la dirigida por el artista Carles Congost, Retorciendo palabra, fuese la que mejor reprodujera el lenguaje estándar del videoclip, al estar vinculada gran parte de su obra con el universo adolescente. Es muy similar a la pieza realizada por Martín Sastre, La mano en el fuego, en el que el propio artista interpreta la canción. Ambos temas fueron singles, y los vídeos realizados se utilizaron como materia promocional. Sin embargo para la emisión de La mano en el fuego, se grabaron nuevos planos con Alaska interpretando la canción, imágenes que sustituyeron a las de Sastre.

Destaca también la pieza del artista Christian Jankowski, Nadie mejor que tú, en la que se ve a la cantante Marta Sánchez interpretando en play back la parte vocal grabada por Alaska. Se intenta jugar así con la confusión del espectador. Una pieza que tendría complicada su elección como acompañamiento para un single promocional, debido a su difícil comprensión. "Creo que llegaría a tener un nivel de comprensión muy corto, porque incluso en el contexto en el que la gente lo ve, que es alguien que tiene el disco original y se lo ha llevado a su casa, que te conoce, te das cuenta cuando la gente te pregunta que no lo han entendido en absoluto, que ha llegado a muy poca gente. Ha estado proyectado en Vigo, (en la exposición Switch on the power) y la gente dice "es Marta Sánchez" pero no lo asocian con la vOz." 5

Es necesario conocer el tema musical y saber que lo interpreta otra artista para no caer vampirizado por la imagen y creer lo que se ve,

\footnotetext{
${ }^{4}$ Alaska, entrevista realizada por el autor

${ }^{5}$ Alaska, entrevista realizada por el autor
} 
que Marta Sánchez está interpretando el tema. En realidad se trata de un juego entre iconos de la música pop española. El autor de la pieza utiliza el potencial de la imagen para mostrar algo que realmente no está pasando, cómo la imagen vale más que lo que se escucha, la música que, en teoría, debería ser lo que se vende en la industria musical. El espectador que no se cuestione lo que ve, que no preste atención a la banda sonora del vídeo, creerá que Marta Sánchez interpreta el tema.

Algunas piezas como la de Marina Núñez, El arte de decir no, se aleja casi por completo de la estética del vídeo musical. Menos lúdica que el resto de las aportaciones, muestra lo que podría ser una instalación: la cabeza de la cantante Alaska con una gran melena que desemboca en diversos objetos, como una paloma, una casa, etc. Los planos no están montados según el ritmo de la música y las imágenes tratan de no mostrar el rostro de la cantante, que no se ve hasta el final.

Adiós, de Manu Arregui, e Interior de una nave espacial abandonada, de Ruth Gómez, utilizan técnicas de animación digital. Ambas piezas se adaptan muy bien al espíritu de la canción, pero evitan mostrar referencias fotográficas tanto de Olvido como de Nacho Canut en sus imágenes. Únicamente la pieza de Ruth Gómez presenta algunos dibujos vectorizados del dúo.

Por el momento esta iniciativa es única en el panorama musical y artístico español. Mezcla dos vías de distribución del videoclip: la de exhibición pública en espacios culturales y las posibilidades del formato DVD para ser incluido y puesto a la venta en un mismo pack junto al CD. Las dos únicas vías que podrían utilizar al ser un producto no destinado a la promoción del disco.

Una iniciativa que aúna dos mundos, el de la música popular y el mercado artístico. Ambos encuentran una de sus uniones en el antivídeo, a menudo ignorado por ambos sectores. El comisario independiente y director del Centro Cultural Montehermoso de Vitoria-Gasteiz, Xabier Arakistain, explica parte de la reacción que en el mundo del arte puede suponer el vídeo musical. Lo hace en el libreto interior de Arquitectura Efimera : "Pero si los museos y los centros de arte tienen que salvaguardar y mostrar los bienes artísticos 
de los pueblos de los que forman parte, no podemos dejar de exigir que, por ejemplo, las programaciones habituales de los museos públicos dejen de ignorar, por que lo hacen de forma escandalosa, las obras y discursos de artistas mujeres o de otros colectivos minorizados. O que no se cierren a otro tipos de eventos, por ejemplo los relacionados con la música popular, por que todavía no han conseguido alcanzar un estatus significado en los medios artísticos".

\section{Conclusiones}

Como se ha comprobado, es habitual encontrar el formato del vídeo musical en entornos de exhibición de actividad plástica. Aunque la causa estética y experimental es la mayoritaria es común encontrarlo bajo otras escusas como son el estudio de un formato televisivo o vinculado con ciertos movimientos sociales.

Los vídeos musicales exhibidos en entornos artísticos suelen estar vinculados con prácticas del mismo entorno, piezas que se alejen del lenguaje habitual relacionado con la publicidad. Es normal que las piezas seleccionadas estén dirigidas por personas ajenas a la televisión o la publicidad y relacionadas con la creación plástica. Por otro lado también es importante la selección de vídeos realizada por en base a alguna innovación técnica a nivel visual. Estas dos vertientes, la que se aleja del lenguaje publicitario y los que indagan y experimentan con algún avance técnico son las más representadas en espacios artísticos.

El vídeo musical profundiza mejor en lenguajes artísticos y visuales cuando no hay intención comercial. La necesidad de emitir una videoclip por televisión en un horario de máxima audiencia, o de presentar al cantante o grupo de una determinada forma para facilitar la creación de vínculos identificativos entre el espectador y el público condicionan de gran manera las posibles opciones, tanto plásticas como narrativas, de los vídeos musicales. Esta libertad llega, en muchos casos, a desvincular totalmente la imagen del sonido, con piezas visuales creadas a espaldas de su banda sonora

En relación a otros medios, como Internet o la televisión, las exhibiciones públicas exigen más atención por parte del usuario. Para 
poder visionar las piezas es necesario desplazarse a los sitios donde se exhiben y, en muchos casos, pagar una aportación económica para entrar al museo o al festival. Ya no se ven los vídeos en casa, ahora es necesario salir de ella para ver las piezas, lo que en muchos casos requiere un conocimiento de las fechas y horarios de exhibición o de la programación de estas exposiciones, festivales o ciclos. Es el medio menos vinculado a la promoción, ya que las piezas son expuestas por sus logros visuales/sonoros, no por el artista/grupo que interpreta la canción.

\section{Referencias bibliográficas}

Agger, M "FILM; The Music Video Gets a Retrospective" New York Times. 13, abril 2003. Recuperado el 1 de octubre de 2014 de http://www.nytimes.com/2003/04/13/arts/film-the-music-videogets-a-retrospective.html

Arakistain, X (2007). Switch on the power, ruido y politicas musicales. Nota de prensa. Recuperado el 1 de octubre de 2014 de:

http://www.montehermoso.net/doc/es/ant switch.pdf

Electronic Arts Intermix, (2006) Hoja de pensa. Recuperado el 1 de octubre de 2014 de

http://www.eai.org/pressreleases/12 06 miamimusic pr.html

Kinder, M. "Music Video and the Spectator: Televisión, Ideology, and Dream”. Film Quarterly, Vol.38, No 1. 1984

Nash, M. (1991) "Searching high and low for the art of music video". Nash, -Michael, ed. Art of music video: ten years after. [Catálogo de exposición]. Long Beach Museum of Art.

Nickas, B (2005). Música-vídeo-música. [Tríptico]. Madrid:

Departamento de Audiovisuales del Museo Nacional Cebtro de Arte Reina Sofía. 
Palacio, M. (1987). La imagen sublime vídeo de creación en España 1970/1987. Madrid: Centro de arte Reina Sofía, Ministerio de Cultura.

Sánchez, J. A. (2004): "La vida de las imágenes". Lápiz: Revista internacional del arte. $\mathrm{N}^{\mathrm{o}} 203$.

Sichel, B (2006): “Consideraciones sobre vídeo, cine y museo (I).” En Exit Express, $\mathrm{N}^{\circ} 20$.

Sisario, B. "Music and Design Nod at Each Other" New York Times. 23, octubre, 2014. Recuperado el 1 de diciembre de 2014 de: http://www.nytimes.com/2014/10/26/arts/artsspecial/momaexhibit-is-devoted-to-sound-art.html? $\mathrm{r}=0$

Wager, H. (2004): "Chris Cunningham, Arte de videoclip y videoclips artísticos". Cátalogo de la exposición Chris Cunningham. Come to daddy. Salamanca: Da2. 



\title{
La colección "Catálogos virtuales de exposiciones", de la Facultad de Arquitectura y Urbanismo de la Universidad de Cuenca, Ecuador ${ }^{6}$
}

\author{
José Luis Crespo Fajardo, Universidad de Cuenca (Ecuador)
}

\section{Antecedentes}

\begin{abstract}
A modo de antecedentes, y como planteamiento cualitativo de 1 nuestra argumentación, quisiéramos subrayar cómo a través de la experiencia nos hemos hecho cada vez más conscientes de los beneficios y efectos positivos que comporta para una exposición el contar con un catálogo virtual.

Desde el año 2010 hemos realizado numerosas exposiciones haciendo uso del recurso de la publicación electrónica. Comenzamos desde la edición más básica: CD-ROMs ilustrados con adhesivos y cuyo estuche era una simple bolsa de plástico, pasando por una opción más cartonera en la que el disco se insertaba a un botón de fieltro en una tarjeta decorativa, hasta las ediciones únicamente virtuales, donde la
\end{abstract}

\footnotetext{
${ }^{6}$ Este trabajo científico ha sido patrocinado por el Proyecto Prometeo de la Secretaría de Educación Superior de Ciencia, Tecnología e Innovación de la República del Ecuador. El capítulo se inscribe dentro del proyecto de investigación "Proyección virtual de la producción académica, educativa y creativa", llevado a cabo por el autor en la Facultad Arquitectura y Urbanismo de la Universidad de Cuenca (Ecuador) dentro del Proyecto Prometeo de SENESCYT.
} 
visibilidad del documento se hacía a través de bases de datos y repositorios en línea.

En general, siempre nos pareció fundamental contar con un catálogo debido a que es prácticamente lo único que queda como testimonio de una muestra. A veces las exposiciones conllevan gran trabajo de preparativos y montaje, y salvando alguna entrevista o noticia en prensa, no suele quedar mayor documentación. Por eso el catálogo es tan importante: porque provee una prolongación de la exposición en el tiempo y en el recuerdo.

Sin embargo, en nuestros inicios la realidad a la que nos enfrentamos fue la carencia ayudas gubernamentales para sufragar una edición en papel. Ante esta perspectiva optamos por la edición casera de ejemplares en CD-ROM, los cuales no superaban el centenar. El contenido del disco era un archivo en PDF, que por su ligereza podía subirse eficazmente a bases de datos en Internet, promoviendo de este modo que nuestro trabajo expositivo fuera más accesible. En algún momento utilizamos impresoras de CDs cuyo resultado podría definirse como semi-profesional, dando como resultado una edición bastante presentable, cuyo abaratamiento de costes nos permitía justamente tomar iniciativas como regalar copias a los invitados y asistentes a la inauguración de la muestra.

Con el paso del tiempo hemos tomado conciencia de la eficacia de las publicaciones virtuales, y a la vista de su validez incluso ante los organismos de acreditación del profesorado, hemos iniciado la creación de un sistema que potencie su uso como servicio para el profesorado de la Facultad de Arquitectura y Urbanismo de la Universidad de Cuenca, en Ecuador.

\section{Justificación y definición de términos}

El presente texto se centra en la problemática de la difusión de catálogos de exposiciones elaboradas en la Facultad de Arquitectura de la Universidad de Cuenca. Es uno de los objetivos, dentro de nuestro proyecto de investigación "Proyección virtual de la 
producción académica, educativa y creativa", buscar estrategias para mejorar la visibilidad de las actividades científicas elaboradas desde la Universidad, entre las que hay considerar especialmente las exposiciones.

Para adentrarnos en la cuestión queremos comenzar por una definición ejecutiva del concepto "catálogo de exposición". Consideraremos como catálogo de exposición una publicación puntual que surge a propósito de una exhibición de piezas de valor creativo, histórico o ilustrativo. Su fin es recopilar, mediante un listado de imágenes, las obras que se muestran en la exposición, refiriendo detalles concretos sobre las mismas.

Los catálogos se prestan a multitud de variaciones en cuanto a formato y maquetación. Su contenido puede pasar de un simple listado a adentrarse en otros géneros librescos. No obstante, por lo general se trata de un libro ilustrado en el que las imágenes tienen el papel principal. Ello no es óbice para que contengan un buen aparato crítico. Pueden albergar presentaciones institucionales, ensayos de curadores, textos literarios, estudios de carácter académico, notas y apostillas sobre las obras. También pueden incluir, tratándose de una exposición de artistas, la biografía de los mismos. Por todo ello, es notorio el valor como fuente de investigación de estas publicaciones. Este fin teórico y divulgativo de los catálogos se descubre especialmente cuando surgen de eventos promovidos por instituciones educativas, museos y fundaciones, con carácter no venal, aunque puede haber catálogos -en especial cuando se trata de subastas- que reúnen ambos objetivos.

Un "catálogo virtual de exposición" es en esencia el catálogo digitalizado, si bien puede contener información extra (videos, música, fotografías) accesible mediante enlaces (Herrera, 2002: 121) ${ }^{7}$.

\footnotetext{
${ }^{7}$ El "catálogo virtual de exposición" puede referirse a veces a una exposición virtual, pero se trata de nociones distintas. La diferencia podría yacer especialmente en que en un catálogo virtual no se puede apreciar un paseo o exploración del espacio y los objetos.
} 
Su finalidad puede ser sólo complementaria a la exposición real, sirviendo para ampliar su difusión, o bien puede tener una función independiente, por ejemplo cuando posee contenidos digitales exclusivos, interactividad, acceso mediante enlaces a la visita virtual, documentos de considerable valor teórico, y su lectura se convierte ya de por sí en una experiencia singular.

\section{Planteamiento del problema. Marco referencial o teórico}

En este escrito planteamos la idea de posibilitar la edición online de catálogos como servicio para la comunidad académica. Existen motivos suficientes para proyectar una propuesta formal al respecto, y a continuación pasamos a esbozarlos.

Tradicionalmente los catálogos son publicaciones realizadas en papel, en tiradas cuyos gastos de edición suelen ser sufragados -O auspiciados en parte- por distintas instituciones y organismos que destinan fondos o abren concursos para la promoción de actividades culturales. El grueso de los catálogos precisan reproducir fotografías a color, el factor de mayor encarecimiento. Por tanto, el catálogo es un elemento habitual en muestras de cierto calado, pero que por el contrario no se encuentra en exposiciones sencillas, las cuales no se lo pueden permitir. De tal forma, la opción del catálogo virtual se yergue como una posibilidad real para la edición de este documento complementario a las exposiciones por parte de cualquier autor, puesto que la publicación en línea se efectúa sin apenas costes.

El siguiente motivo surge de la consideración de que las exposiciones son generalmente perecederas. Desde las más humildes a las grandes exhibiciones colectivas, pasando por aquellas itinerantes cuya estrategia es dilatarse en diferentes espacios para aumentar su incidencia. Por mayor número de masas que atraigan su tiempo de exhibición es limitado, y nada queda de ellas si no hay por lo menos un catálogo. Por tanto, si apreciamos el esfuerzo de organización, montaje, acondicionamiento y otras medidas emprendidas, lo recomendable es que estos eventos cuenten al menos con un catálogo como método de perduración. No obstante, es una realidad que 
cuando se trata de pequeñas exposiciones, los catálogos no se suelen conservar con suficiente cuidado. Estas ediciones, pasquines por lo general de tirada corta y sin demasiada calidad en diseño y papel, parecen estar hechas para perecer. Su vida es breve. Su tiempo perdura lo que dura la exposición. Así pues, para terminar con estas circunstancias podemos aprovechar la oportunidad que ofrece la Web de hacer visibles y accesibles estos textos. La presencia online de un catálogo, o bien la exposición virtual de la muestra, son un recurso al alcance de todos que sirve para amortizar el trabajo de ejecutarla y para perpetuarla en el tiempo, evitando que caiga en el olvido, facilitando la búsqueda y recuperación de la información.

Ya que los catálogos son el testimonio de proyectos expositivos, entre sus páginas podemos hallar material documental de estimable valor. Puesto que son en esencia una forma de documentar una exhibición, son susceptibles de ser valiosas fuentes primarias de conocimiento y estudio (Herrera, 2000: 171) ${ }^{8}$. En ocasiones los catálogos hacen pública información exclusiva, novedosa y en detalle sobre temas muy concretos entorno a los que gira la exposición, o bien sobre los artistas. También, por ejemplo, podemos hallar catálogos resultado de una catalogación razonada, donde se revela una clasificación de acuerdo a determinados criterios, así como explicaciones eruditas sobre cada pieza ${ }^{9}$. Estos trabajos suelen ser elaborados por historiadores y curadores, y hay que valorar que ciertas exposiciones llegan a ser planteadas como verdaderas tesis, con nociones y conclusiones originales a través de las cuales el espectador es introducido en el recorrido de la muestra.

\footnotetext{
${ }^{8}$ El trabajo de la historiadora Anna María Guasch es revelador sobre el uso expreso de catálogos como fuentes de investigación primarias. Guasch, A. M. (2000). Los manifiestos del arte posmoderno: textos de exposiciones 1980-1995. Madrid, Akal. Guasch, A. M. (1997). El arte del siglo XX en sus exposiciones: 1945-1995. Barcelona, Ediciones del Serbal.

${ }^{9}$ Algunos catálogos de gran envergadura suponen la distribución de varios tomos. Por ejemplo podemos mencionar el enciclopédico trabajo de Angulo Íñiguez, D. y Pérez Sánchez, E. (1977) A Corpus of Spanish Drawings, Londres, Miller Publishers.
} 
De forma especial queremos hacer destacar que el catálogo es también un elemento educativo, un material pedagógico para docentes y alumnos, quienes pueden encontrar en ellos datos de consulta. Por tanto, a tenor de su utilidad se destaca la conveniencia de que los catálogos se encuentren en línea, favoreciendo la circulación de la información libre y fácilmente accesible.

Finalmente, expongamos que la publicación online tiene un distintivo carácter de sostenibilidad y respeto a la naturaleza, debido a que los libros tradicionales están hechos de papel, material que se extrae de los árboles. Por otra parte, la idea ostenta prestaciones en cuanto a la rapidez de edición, puesto que no intervine aquí el largo proceso de impresión de las obras. Por último, una cuestión de relevancia y sobre la que hemos ya incidido, es que el catálogo online puede generar repercusión y amplitud de difusión en la Web, propiciando el interés general de la comunidad de investigadores, así como su citación e impacto científico, reflejado en estudios de diversa índole.

\section{Propuesta y objetivos}

Mediante este artículo queremos formular la idea de poner a disposición de miembros de la comunidad académica de la Universidad de Cuenca (profesores e iniciativas de alumnos) la posibilidad de que ellos mismos elaboren el catálogo de sus actividades expositivas. La propuesta busca facilitar el proceso de visibilización online de catálogos de arte y arquitectura a través de los repositorios institucionales de la Universidad, así como el de asignación de un número de registro y derechos de autor.

Esta propuesta se establece como un servicio de complemento a las exposiciones que, como ya hemos señalado, se ven notablemente beneficiadas al proyectarse virtualmente. Facilitar el proceso de publicación del catálogo será un incentivo para docentes y para iniciativas estudiantiles, que fomentará la ejecución de exposiciones y la producción académica en el ámbito de la Universidad. 
Nuestro planteamiento consiste en la creación de una colección de catálogos online de exposiciones cuya visualización y descarga se efectúe a través de una pestaña (TDI) dedicada a publicaciones en la página web de la Facultad de Arquitectura y Urbanismo de la Universidad de Cuenca

En concreto proponemos crear una colección dedicada a muestras expositivas de arte y arquitectura surgidas desde el profesorado o por iniciativa de alumnos. Se facilitará el acceso abierto y el registro pertinente como publicación siempre que se cumpla con una serie de requisitos.

Para empezar, para poder contar con respaldo institucional de la Universidad, lo primero que hay que contemplar es que dadas las actuales directrices del Servicio de Publicaciones, es preciso que exista una estricta revisión por pares del documento original. Para tal fin, la colección de catálogos de exposiciones contará con un consejo científico integrado por académicos de diferentes instituciones, nacionales y extranjeras, quienes se comprometerán a revisar y arbitrar los documentos que se presenten. Esta revisión se hará acorde a un formato predeterminado, y en caso de ser positiva se ubicará en los preliminares del catálogo a modo de aprobación. Por otra parte, el Servicio de Publicaciones facilitará la gestión de obtención del código de Derecho de Autor, y un número de ISBN. Asimismo, estamos gestionando el proceso de solicitud de un código DOI (Digital Object Identifier) para las publicaciones electrónicas de la Facultad de Arquitectura y Urbanismo de la Universidad de Cuenca.

Parece importante que las obras estén registradas con derecho de autor, especialmente para proteger la propiedad intelectual ante posibles fraudes y distribución de imágenes bajo otra autoría. Aún así, resulta del todo conveniente favorecer el libre uso, copia y reproducción de las imágenes, siempre y cuando se cite su autor y se indique su procedencia y localización en Internet. Se ha de buscar potenciar el modelo de Copyleft con el fin de favorecer la divulgación en internet de la obra, posibilitando que las imágenes se empleen en 
cualquier tipo de publicación o entorno sin ánimo de lucro y que circulen ampliamente por el ciberespacio.

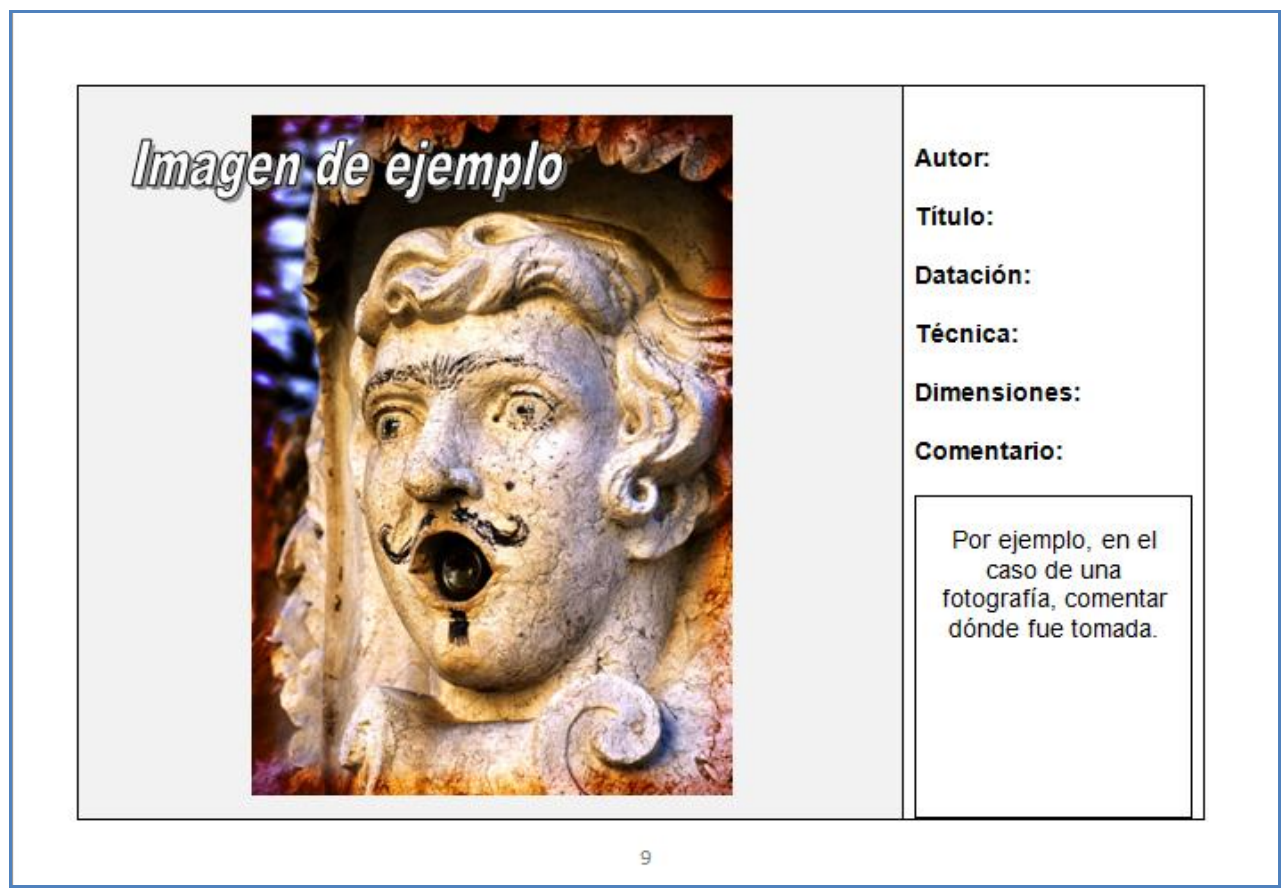

Ficha catalográfica en la plantilla modelo para la colección.

Para dar un mejor servicio a la comunidad académica de la Universidad y simplificar el proceso de elaboración del catalogo, planteamos la fórmula de poner a disposición de los usuarios una plantilla, un modelo guía de catálogo para completar. El formato del documento de plantilla será básico, elaborado en el procesador de textos Word, con un estilo visual homogéneo para toda la colección. Sobre este documento el interesado podrá trabajar, sustituyendo la información explicitada por la suya propia. En cualquier caso, hay que recalcar que esta opción surge para facilitar una elaboración adecuada del catálogo a aquellas personas que no poseen conocimientos de diseño gráfico, por lo que para aquellos que sí cuentan con la destreza se deja abierta la opción de utilizar programas de maquetación, siempre que cumplan con los requisitos estipulados en las normas de la colección.

La estructura de la plantilla de catálogo ha de revelar cierto grado de cientificidad. Por ejemplo, ya hemos comentado que debería 
anteceder a modo de aprobación los informes de los revisores. No obstante, será también de interés que se incluya un prólogo firmado por una autoridad académica o de prestigio. Es evidente que el crédito de una exposición viene de alguna forma refrendado por los ensayos que se incluyen en el catálogo. Son contemplados como un aval de la calidad de la exposición, especialmente si provienen de una personalidad de relevancia académica ${ }^{10}$.

Desde las primeras páginas, en los créditos, ha de expresarse con claridad que aunque se favorece el uso Copyleft del material de la obra, han de respetarse los derechos de autoría y el uso no comercial de las imágenes. Se debe especificar el proceso correcto para su reproducción, citando al autor y procedencia.

En los preludios ha de reservarse espacio para la presentación y agradecimientos. Posteriormente puede haber cabida para otros estudios, y en este sentido se ha de promover la inclusión de textos de relevancia, que ofrezcan datos inéditos o bien contengan aportaciones de originalidad. Esto favorece el impacto de la exposición, atrayendo a investigadores que reflejarán la importancia del documento en sus propias publicaciones.

Junto a cada imagen ha de haber una completa ficha catalográfica en la que se recogerá información sobre la obra: autor, título, datación, técnica, dimensiones y un comentario, si procede. La ficha supone un aporte de datos fundamental para el estudio y una referencia de fiabilidad sobre la seriedad con que se ha comisariado la muestra.

Al final del catálogo podemos incluir una bibliografía relacionada, un aparato crítico. También es de importancia reflejar una breve biografía de los autores y direcciones de contacto. El catálogo puede contener materiales que quizá no se muestran en la exposición, pero que son relevantes, como por ejemplo imágenes o vídeos, fotografías

\footnotetext{
10 Por ejemplo un decano, director de departamento o catedrático. De tal forma, podría un prólogo que reúna estas características ser aceptado como revisión, agilitando el proceso de evaluación por pares.
} 
del montaje, la inauguración, el making-off, todo lo cual podría estar enlazado por hipervínculos a otras webs.

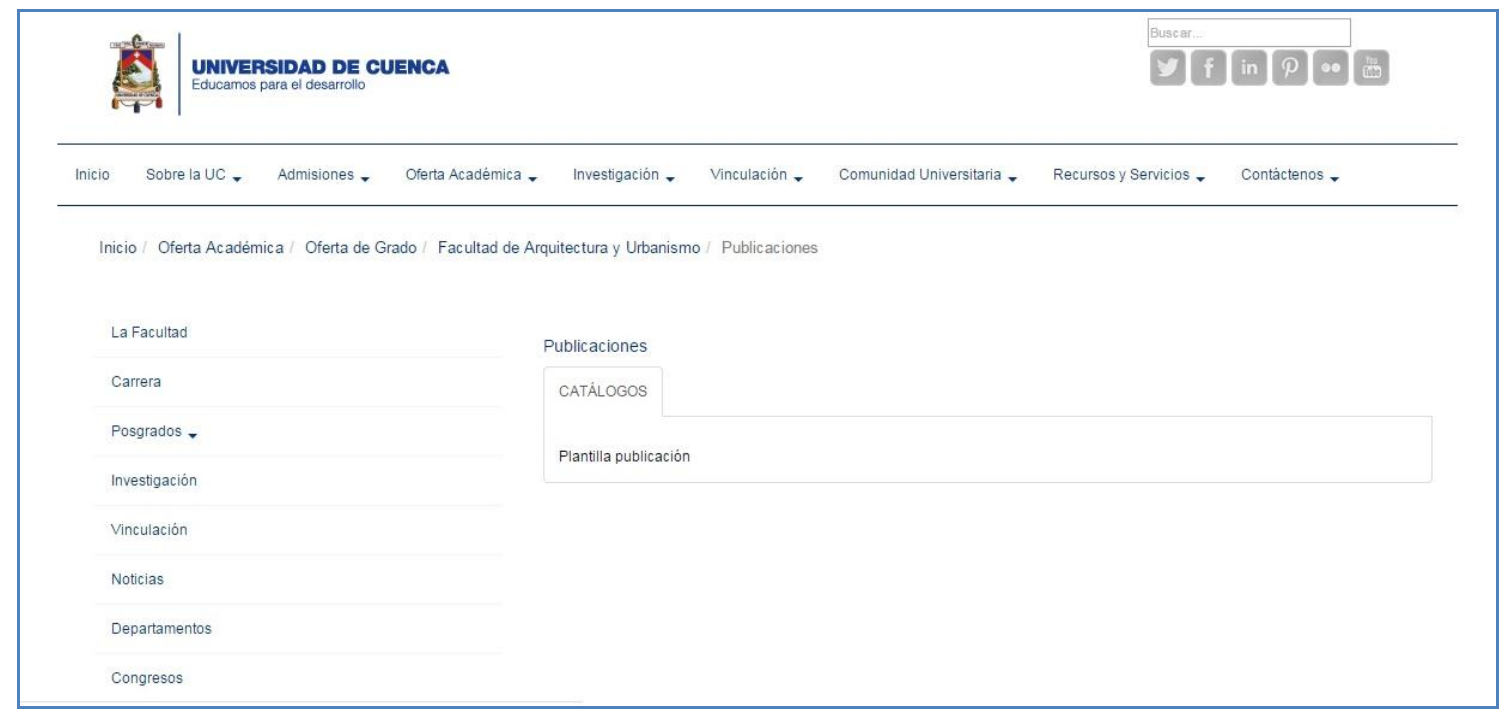

Interfaz de la página web de la Facultad de Arquitectura y Urbanismo de la Universidad de Cuenca, con la pestaña dedicada a Catálogos (En Beta)

Otro aspecto de importancia es que, para mejorar el alcance de la publicación, en la plataforma habilitada habría de confeccionarse, por cada catálogo, una correcta referencia bibliográfica en español e inglés. Es decir, un resumen descriptivo de la obra con palabras clave en ambos idiomas, con el fin de facilitar la captura de metadatos en los buscadores de Internet. De este modo se gana en internacionalidad, proyectándose y promocionándose dilatadamente las obras de arte y arquitectura de los autores de la Universidad de Cuenca.

Finalmente, hay que subrayar que el éxito de esta propuesta sería el resultado de una propicia cooperación interdepartamental, especialmente entre el Servicio de Publicaciones y el Consejo Editorial de la Facultad de Arquitectura y Urbanismo de la Universidad de Cuenca, contando además con el correcto seguimiento de las directrices por parte de los autores-usuarios que hagan uso de esta posibilidad de publicación online de catálogos. 


\section{Metodología}

En la ficha de descripción de cada catálogo, y especialmente en el interior del mismo, puede jugarse con la capacidad interactiva que nos brinda el hecho de tratarse de publicaciones virtuales. A través del formato digital se enriquece sensiblemente la comunicación, dinamismo y atractivo general de cara a la transmisión de contenidos.

De tal forma, es posible integrar imágenes, animaciones, videos, música, enlaces... A través de hipervínculos se puede visionar el álbum de fotografías de la exposición, la inauguración, montaje, clausura, etc., en una galería que puede estar alojada en plataformas de imágenes o en redes sociales. Otros enlaces pueden dar acceso a documentación: folletos, carteles, horarios. Es posible también mostrar vínculos a plataformas de videos donde encontrar, entrevistas relacionadas, grabaciones, tomas de la exposición e información mediática. Resulta particularmente interesante que el catalogo virtual enlace a noticias de prensa y medios de comunicación (periódicos digitales, noticiarios), referidas a la exposición, porque así se recoge a modo de prueba perceptible la magnitud y repercusión del evento.

Por otra parte, a través de la nota de prensa anunciadora de la exposición publicada en un medio de comunicación digital se puede generar interés por la asistencia a la muestra real, pues la propia nota puede contener ya los vínculos al catálogo, accediéndose, por ejemplo, con un clic sobre el hipertexto subyacente al nombre de la exposición. Efectivamente, un catálogo online puede ser un atractivo para que un potencial espectador se interese por la exposición real, pero su primordial sentido es que sirva como contenedor de toda la información gestada y producida antes y a rebufo de la muestra. De esa forma quedará almacenada virtualmente y no se perderá. Será motivo de investigación, generando conocimiento libre y global sobre lo que se hace en la Facultad de Arquitectura y Urbanismo de la Universidad de Cuenca, Ecuador. 
Existen otras posibilidades que pueden contemplarse como puntos a favor de la virtualidad de los catálogos. Por ejemplo, es fácil visualizarlos en pantallas y a través de proyectores, prestándose como un recurso apropiado para presentaciones en eventos y clases magistrales. Esta cualidad nos puede ser de utilidad a la hora de realizar la inauguración de la muestra ante un público. En el acto podemos proyectar el catálogo y mencionar datos amenos, anécdotas sobre el montaje y la gestación de las obras. Otra opción de interés es ubicar en la propia sala de exposiciones una pequeña pantalla -o un simple portafotos digital- con las páginas del catálogo pasando de manera automática. Por último, el hecho de que se pueda acceder a publicaciones en línea desde smarthphones y tablets nos da la posibilidad de hacer visible un código QR en la sala de exposiciones, el cual dará acceso al catálogo virtual, facilitando que los espectadores puedan visualizarlo en sus terminales.
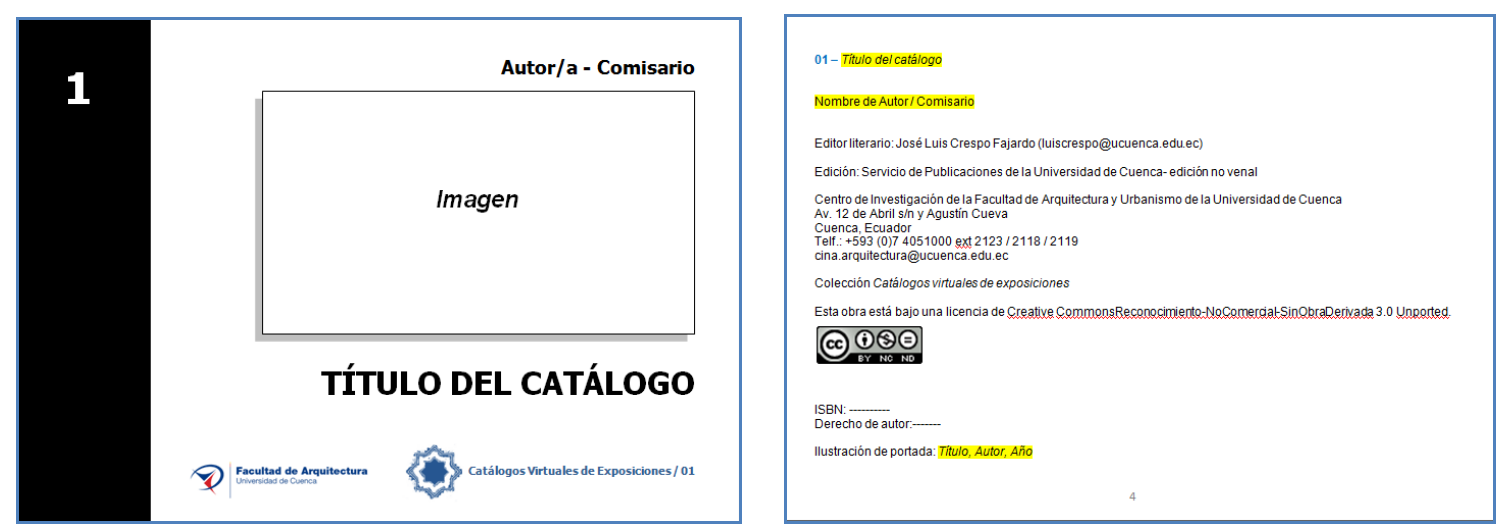

Plantilla modelo para la colección de "Catálogos virtuales de exposiciones"

Uno de los objetivos cardinales agregados a esta propuesta es facilitar la visualización de los catálogos a escala global. Para tal fin, la estrategia más oportuna es contactar con bases de datos internacionales y hacerles llegar los archivos digitales para que desde sus repositorios puedan darles amplia visibilidad y suscitar el interés académico. En este sentido, nuestro principal valedor podría ser la base de datos Dialnet (Universidad de la Rioja) con quien la Universidad de Cuenca habría de estudiar establecer un convenio. 
Para terminar, una idea factible podría ser la difusión en redes sociales de la colección de catálogos virtuales de exposiciones, subrayando que se trata de un recurso gratuito y de libre acceso. Esta estrategia viral estaría acorde a otras efectuadas en Facebook. Por ejemplo, en Diciembre de 2012 se hizo viral a través de esta red la oferta de libros gratis como regalo de Navidad, informando que el Metropolitan Museum of Art de Nueva York había puesto a libre disposición un recurso con 400 libros de arte gratuitos digitalizados. No obstante, el portal de acceso, llamado MetPublications, estaba operativo desde mediados de 2012 con obras modernas y clásicas del siglo XIX para su lectura online o descargables en $\mathrm{PDF}^{11}$.

\section{Posibles resultados y conclusiones}

Actualmente somos testigos de un proceso de digitalización de la cultura. Las instituciones culturales y educativas están interesadas en que sus muestras expositivas pervivan más allá de lo perecedero y efímero de la exposición real, por lo que dedican sus esfuerzos editoriales a la divulgación en línea de sus colecciones, productos e investigaciones. Invertir en la difusión online es optimizar esfuerzos, pues el objetivo de la producción formativa, investigativa y creativa surgida en el seno de la Universidad es que sea conocida por el mayor ratio de miembros de la comunidad académica internacional.

En lo referente a las exposiciones, hemos de convenir que son en sí mismas un instrumento de divulgación de objetos de creación, valor patrimonial o documental. Las exposiciones han de ser concebidas como un medio de comunicación cultural, cuyo fin es transmitir saberes, ideas, valores y emociones. El catálogo es su plasmación sintética, por lo que tiene todo el fundamento tratar de aumentar su difusión.

La colección de catálogos virtuales de exposiciones resultará ser de gran interés para el profesorado de la Facultad de Arquitectura y Urbanismo de la Universidad de Cuenca. Esperamos que pueda tener

${ }^{11}$ Véase en: http://www.metmuseum.org/research/metpublications/ (Fecha de consulta 24/11/2014) 
un objetivo práctico de cara a la docencia, favoreciendo la puesta en marcha de exposiciones de carácter didáctico, alentando a hacer uso de las Nuevas Tecnologías a los profesionales de la educación universitaria, quienes pueden hallar en este recurso una oportunidad para implementar las TICs en los programas académicos, por ejemplo programando una exposición de los trabajos de clase al final del año, con su correspondiente catálogo online. Para los estudiantes, futuros artistas y arquitectos, sería una experiencia plenamente aleccionadora, y por medio del catálogo online, además de amortizar el esfuerzo del montaje expositivo, encontrarán un espacio de transmisión perdurable para sus obras.

\section{Referencias bibliográficas}

Herrera Morillas, J. L. (2000) "Catálogos de exposiciones de Bellas Artes: Propuesta metodológica para su estudio a partir de la elaboración de un repertorio bibliográfico. Un caso concreto: los catálogos de exposiciones de Bellas Artes andaluzas (1987-1996)" En Cuadernos de documentación multimedia, 10, Universidad Complutense de Madrid, p. $171-184$.

Herrera Morillas, J. L. (2002) "Páginas Web Sobre Exposiciones Virtuales De Fondo Antiguo: Recopilación y Análisis." En El profesional de la información, vol. 11, 2. p. 121-136. 


\title{
Sigue el Camino de Baldosas Amarillas ${ }^{12}$. El tránsito indagador para los estudiantes de Bellas Artes a través del recurso metodológico test- indagación
}

\author{
Laura de Miguel Álvarez, Facultad Artes y Letras. Universidad \\ Antonio de Nebrija
}

\section{Introducción}

CoN este título se presenta un texto que versa sobre la importancia de valorar el proceso que se recorre, durante una investigación desde la práctica artística como parte indivisible de su resultado final, e incluso, como obra de arte en sí misma. En los últimos cuarenta años el paradigma de investigación en Bellas Artes ha ido cambiando, pues desde que éstas entraron en la universidad muchas han sido las investigaciones producidas por artistasinvestigadores a lo largo de nuestra geografía, que han tratado temas colindantes al arte, pero sin plantear su propia práctica como foco explícito del estudio en cuestión. Progresivamente, la aparición de trabajos de investigación dentro de la universidad, que se colocan en

\footnotetext{
${ }^{12}$ Título de una de las canciones que aparecen en la película "El Mago de Oz" (The Wizard of $O \approx$ ) , 1939, acuñado por la estudiante Elena San Juan en su valoración escrita de la asignatura donde surgió el método Test-indagación. Curso académico 2013-2014. Grado en Bellas Artes. Universidad Nebrija.
} 
la perspectiva en, desde y a través el arte (Investigación Artística ${ }^{13}$ ) es un hecho y no sólo la sucesión de "planteamientos de intención" expuestos desde supuestos reflexivos y teóricos, alertando de la necesidad de que se produzca el cambio de paradigma en esta área de conocimiento.

Desde el momento actual (en el que ya contamos con trabajos de investigación que se colocan dentro de la perspectiva que valora el proceso de práctica artística como manera de generar conocimiento), el texto plantea un método de trabajo para/con los estudiantes de Grado en Bellas Artes, que la autora lleva desarrollando tres años dentro del área de proyectos, con el objetivo de ayudar al alumnado ${ }^{14}$ a obtener pistas para valorar su propia práctica, a través de la elaboración de diversas prácticas de carácter artístico que se engloban en la propuesta denominada Test-Indagación. Éstas, desde su generación, les permiten asimilar las posibilidades reflexivas e introspectivas que la creación artística ofrece como motor de investigación dentro del marco académico universitario.

Este recurso metodológico (el Test-indagación), contribuye también a la modulación del paradigma de investigación en Bellas Artes desde la práctica, en el que la narración y generación de evidencias que supongan vestigios de experiencia a partir del tránsito artísticoinvestigador, supone una de las únicas maneras que actualmente se ha

\footnotetext{
${ }^{13}$ En el texto se plantea "Investigación Artística", como aquella perspectiva indagadora que no solo muestra el resultado finito de un proceso artístico (la obra en sî), sino que también se detiene en el proceso de generación de dicha obra, siendo este incluso exponente del discurso (a través de diferentes formas narrativas: textuales, visuales, audio/visuales, performativas, etc.) que presenta la investigación.

${ }^{14} \mathrm{El}$ material a partir del cual se ha elaborado este texto corresponde al trabajo desarrollado en mi labor docente dentro del área de Proyectos del Grado en Bellas Artes, de la Universidad Nebrija, desde el año 2012. Así, deseo otorgar el reconocimiento que merece a los estudiantes que me han ayudado con su feedback a moldear y evolucionar la propuesta metodológica de Test-indagación en estos años. Método en constante revisión y adaptación en función del perfil del grupo al que se proponga como recurso didáctico dentro del espacio aula/taller.
} 
fijado ${ }^{15}$ para hacer transcender el conocimiento que se construye de manera individual o colectiva (según si es una práctica íntima o compartida).

\section{Test-Indagación: El camino de baldosas amarillas}

Las experiencias son el tejido de la vida. Una a una conforman el camino de aquel que las vive en primera persona. Son las que constituyen nuestro pasado y, a su vez, contienen la "sensación de presente". Y digo "sensación de presente" porque eso es lo que es, algo que se siente en un instante y que a partir de él éste pasa a formar parte de nuestro pasado. Luego entonces el único modo de conocer una experiencia del presente es a través de ubicarla en su tejer y transmitirla. Son muchas las maneras de hacerlo (a través de literatura, imagen, mapas, audio, video, etc.), pero pocas las formas de recibir lo narrado. Existe una esencialmente: a través de los sentidos (oído y vista principalmente). Si tenemos en cuenta que el arte es aquello que estimula y provoca nuestros sentidos, sin cuyas percepciones no podría darse este acto de comunicación, podemos comprender que sus diversos lenguajes resultan esenciales herramientas para la construcción de narraciones que den forma tangible a nuestra memoria con cierto carácter de veracidad desde el momento en que lo pensado por uno mimo se hace tangible para los demás, se discute, se juzga, se alaba, se copia, se argumenta, se rebate; en definitiva, se comparte.

La confección de un relato que narre un acontecimiento puede ser tomado como hecho creativo, pero además brinda una construcción abierta a los múltiples significados que de ella se extraigan en su conocimiento posterior. Esa posibilidad de desplazar el sentido es una manera en sí misma de investigación dentro de la propia investigación, que se construye y reconstruye en la incansable

\footnotetext{
${ }^{15}$ Seminario: "La investigación artística, difusión editorial y criterios de valoración". 17 de octubre de 2014. Edificio Nouvel. Auditorio 200. Museo Nacional Centro de Arte Reina Sofia. Madrid.
} 
búsqueda de sentido hacia el establecimiento de una manera de hacer investigación/arte.

Pero no podemos dejar de lado en este punto que, la narración de una historia, es el modo en que solemos disponer el contenido de aquello que queremos hacer transcender como investigadores, cuya "lectura" suele ser lineal y cronológica, lo cual no encaja muy bien con la naturaleza volumétrica, espacial, circunstancial del suceder artístico. Pues si la construcción de evidencias a lo largo del proceso supone una de las maneras de construir y avanzar a lo largo del mismo gracias a la elaboración de materiales de orden narrativo y marcado carácter artístico, ¿Cómo podemos configurar un proceso indagador para ser compartido a partir de la práctica artística cuyo hecho se produce de forma multidimensional?

\section{Descripción del método y algunas referencias}

Un test, normalmente, es una prueba destinada a evaluar conocimientos, aptitudes y/o funciones. La palabra test, de origen inglés, significa prueba y tiene su equivalencia en la acepción examen. Los test, que suelen realizarse para evaluar de manera "objetiva" los conocimientos que han adquirido los alumnos sobre un tema determinado, pueden ser de preguntas abiertas o cerradas. En esta ocasión, para nombrar el método diseñado como recurso didáctico para la experimentación y generación de evidencias que nos ayuden a hacer transcender el proceso indagador de la práctica artística, se ha recurrido a la acepción test para designar la propuesta que trata de integrar las prácticas que se van ofertando a los estudiantes a lo largo de un cuatrimestre, en un "contenedor" que aporte una nueva visión del proceso desarrollado.

El Test-indagación supone una apuesta metodológica que está enmarcada actualmente en el área de proyectos, más concretamente en la asignatura de Creatividad y Proyectos. Al principio de esta asignatura se plantea el matiz diferenciador de carácter epistemológico entre investigación e indagación. Apoyándonos en la RAE: La investigación supone realizar actividades intelectuales y experimentales de modo sistemático con el propósito de aumentar el conocimiento; y la indagación intenta averiguar, inquirir (examinar 
cuidadosamente), discurrir, cuestionar... Queda claro pues, que donde la investigación busca ampliar el conocimiento sobre algo concreto, la indagación ofrece la posibilidad de aumentar nuestra sensibilidad sobre el todo.
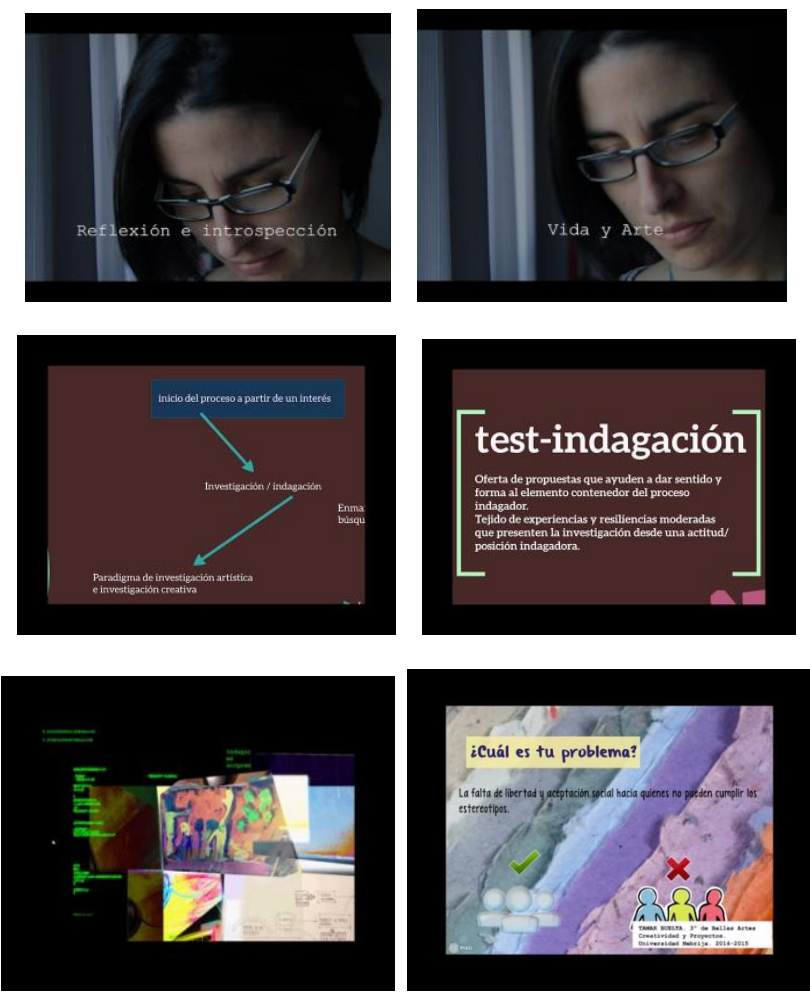

Fig1. Frames de la pieza audiovisual "Test-Indagación: una propuesta metodológica”. Laura de Miguel. Abril 2015. Congreso CICREART VIRTUAL.

[Disponible en: https://www.youtube.com/watch?v=E2Lc7GqaOqQ]

Esta propuesta metodológica, parte de la localización de un interés que los estudiantes escogen libremente, que suponga un punto que les motive lo suficiente como para iniciar un proyecto de investigación a partir de él. Este interés puede estar relacionado con cualquier área de conocimiento. El objetivo principal sobre el que establezco esta metodología, tiene que ver con la estimulación permanente de la creatividad para conocer las diferentes maneras de hacer que tiene cada estudiante, a fin de que durante el proceso de indagación artística tomen conciencia de sus poéticas indagadoras para guiar sus proyectos presentes y futuros. En definitiva, esta autoexploración a la que hago referencia trato de provocarla a partir del diseño de propuestas práctico-reflexivas que invitan a la acción artístico- 
narrativa. Las diferentes propuestas que conforman el test van dirigidas en todo momento al interés/tema que les hizo comenzar su tránsito indagador. Cada propuesta es planteada de diversas maneras, invitándoles a que sea resuelta sin que necesariamente la solución dada tenga que ser escrita, sino que puede ser visual, audiovisual, sonora, plástica, etc. Actualmente, el test comprende un total de once actividades.

Selección de enunciados (propuestas) y de resultados

A continuación aporto una selección de los enunciados que encabezan algunas de las propuestas que actualmente componen el test, seguidos de la selección de algunas de las soluciones dadas por los estudiantes de los niveles de $3^{\circ}$ y $4^{\circ}$ del Grado en Bellas Artes de la Universidad Nebrija.

\section{Narrativa visual}

Elabora una narrativa visual.

El tema sobre el que debes plantearla es Las "cosas" (asuntos) de tu investigación. Estado actual.
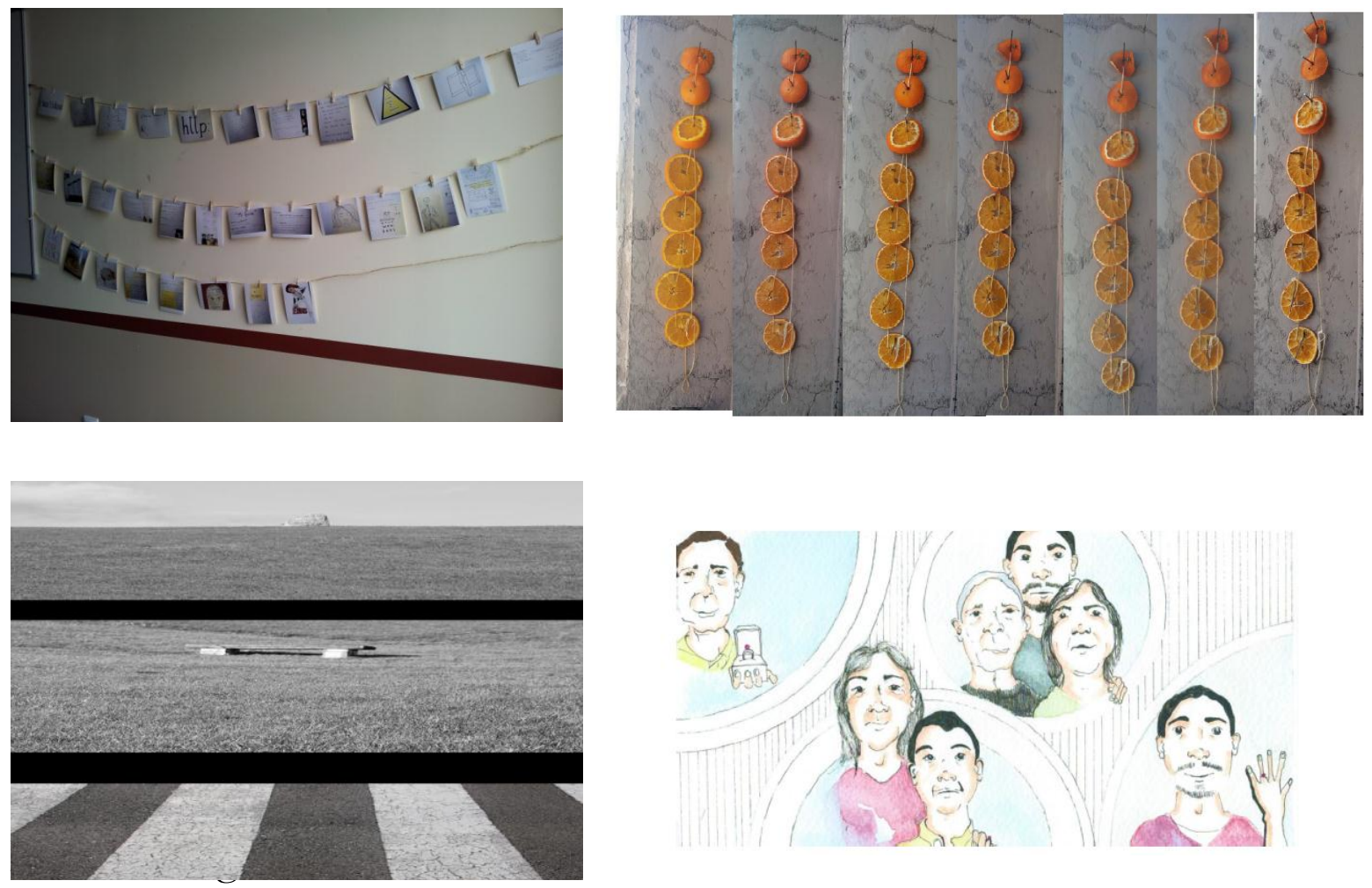

Fanfa, Margarita, Natalia, Ana R. 


\section{Collage narrativo}

Entrena realizando diferentes mapas conceptuales y narrativos (a través de textos, imágenes, signos, etc) que incluyan los dos sistemas para abordar un proyecto de investigación, tal y como hemos visto en clase: aspectos básicos de una investigación y secuencia: idea, concepto, contexto, encuadre y posicionamiento.

Relaciona cada uno de ellos en el espacio físico del soporte utilizado con tu tema de investigación.

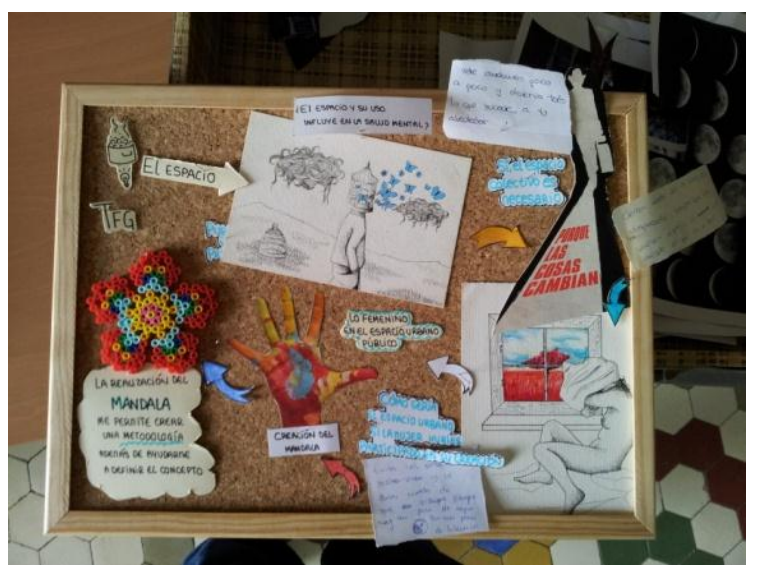

6. COLLAGE NARRATIVO

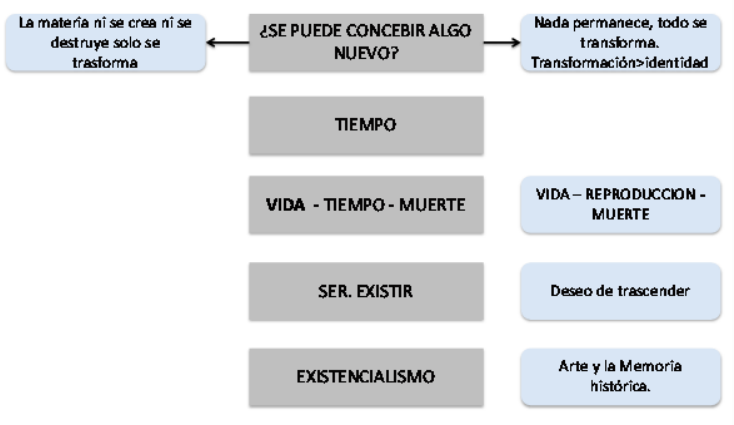

El lector mantiene viva la obra una vez muerto el autor
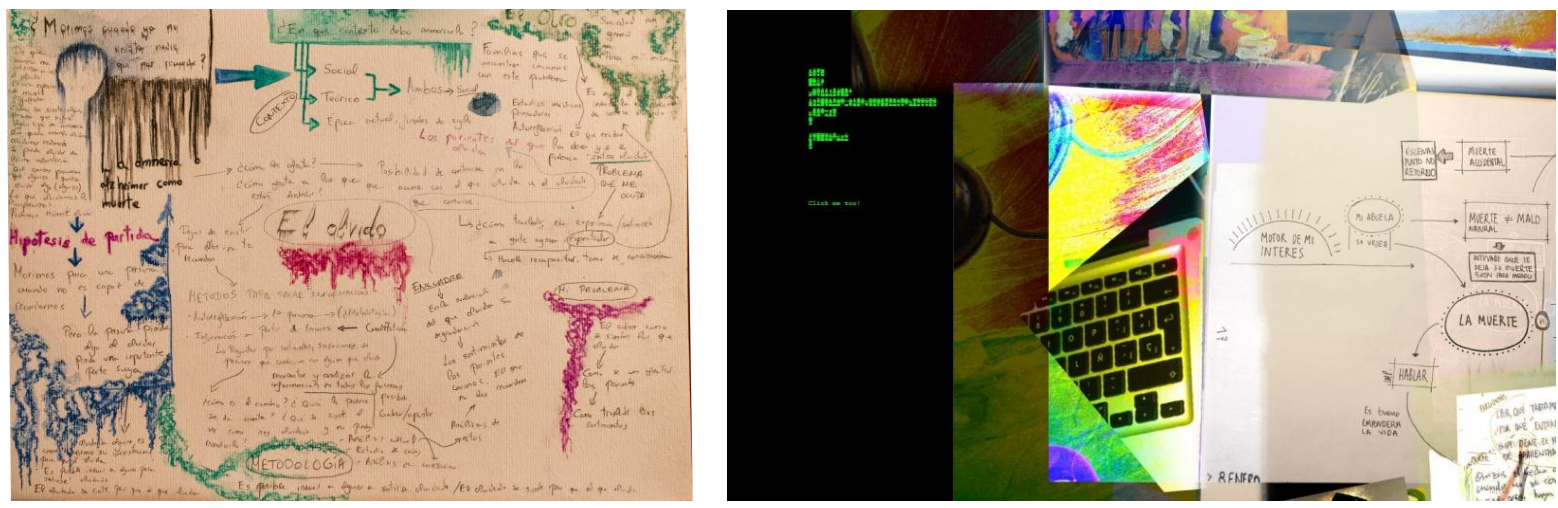

Ana, Margarita, Adriana, Pablo.

\section{Relato Corto}

Debéis explorar esta forma narrativa, a fin de que podáis inscribirla en vuestro proyecto de investigación en curso, en relación como ya sabéis a vuestro interés/tema. 


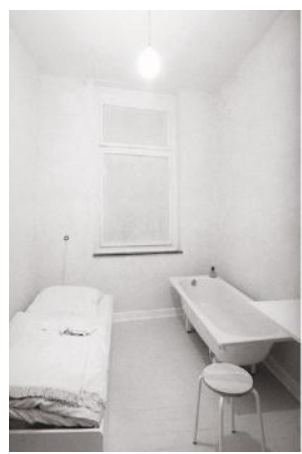

RELATO CORTO

La soledad se adueña de si y sueña

mañana con la vida y la muerte de

la mano. Sin olvidar su huida, sin

olvidar su duda. Llena de fuerza

invisible camina. De seguir todo igual,

estarla mi piel cicatrizada en surcos.

Subí al metro, como todos los días; pegado a la puerta.

Una parada tras otra, demasiada gente, como siempre.

El metro se paró.

Su mirada quedó fija justo frente a la mía. Profunda, intensa, transmitía tantas sonrisas, alegrías; transmitía desamor, esperanza, ilusión y reencuentro.

Los ojos le brillaban por la emoción de reencontrarse. Toda la historia de amor en una mirada. Me estremecí.

Las puertas se abrieron y se acercó a mí. De pronto, pasó de largo.

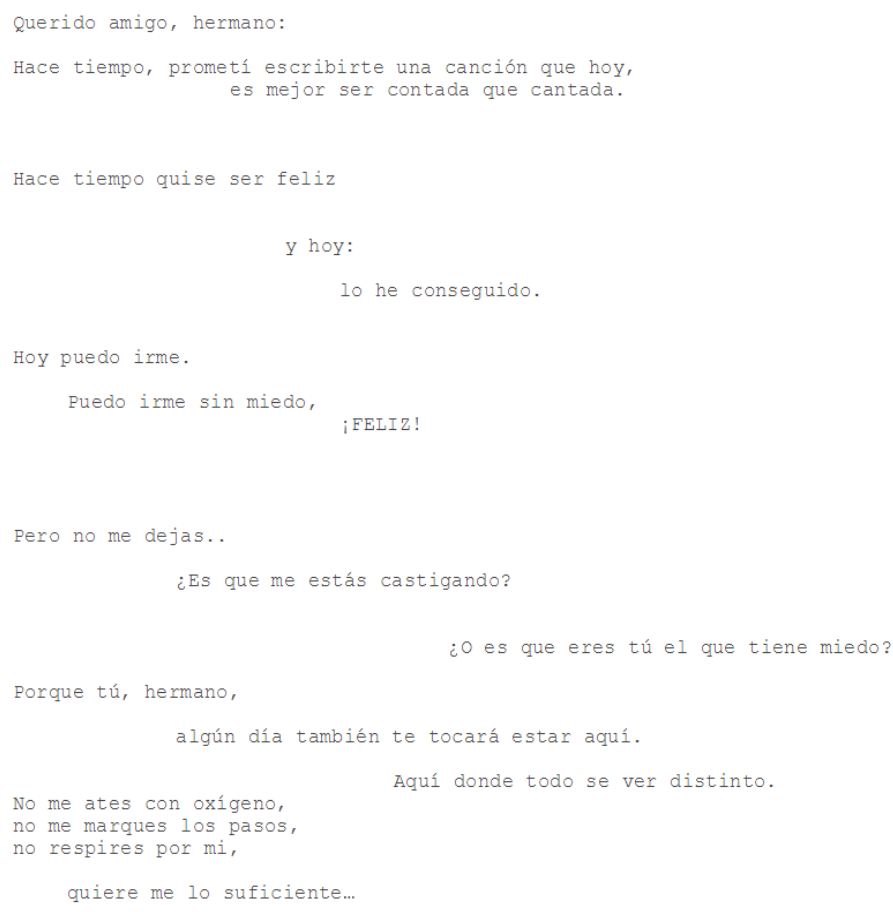

Ana R., Miriam G., Pablo.

\section{¿Qué es investigar?}

Trata de dar una respuesta a la pregunta formulada que no necesite una definición formal a través de la palabra.

Utiliza cualquier recurso creativo y/ o técnico puesto a tu disposición para bacerlo. 

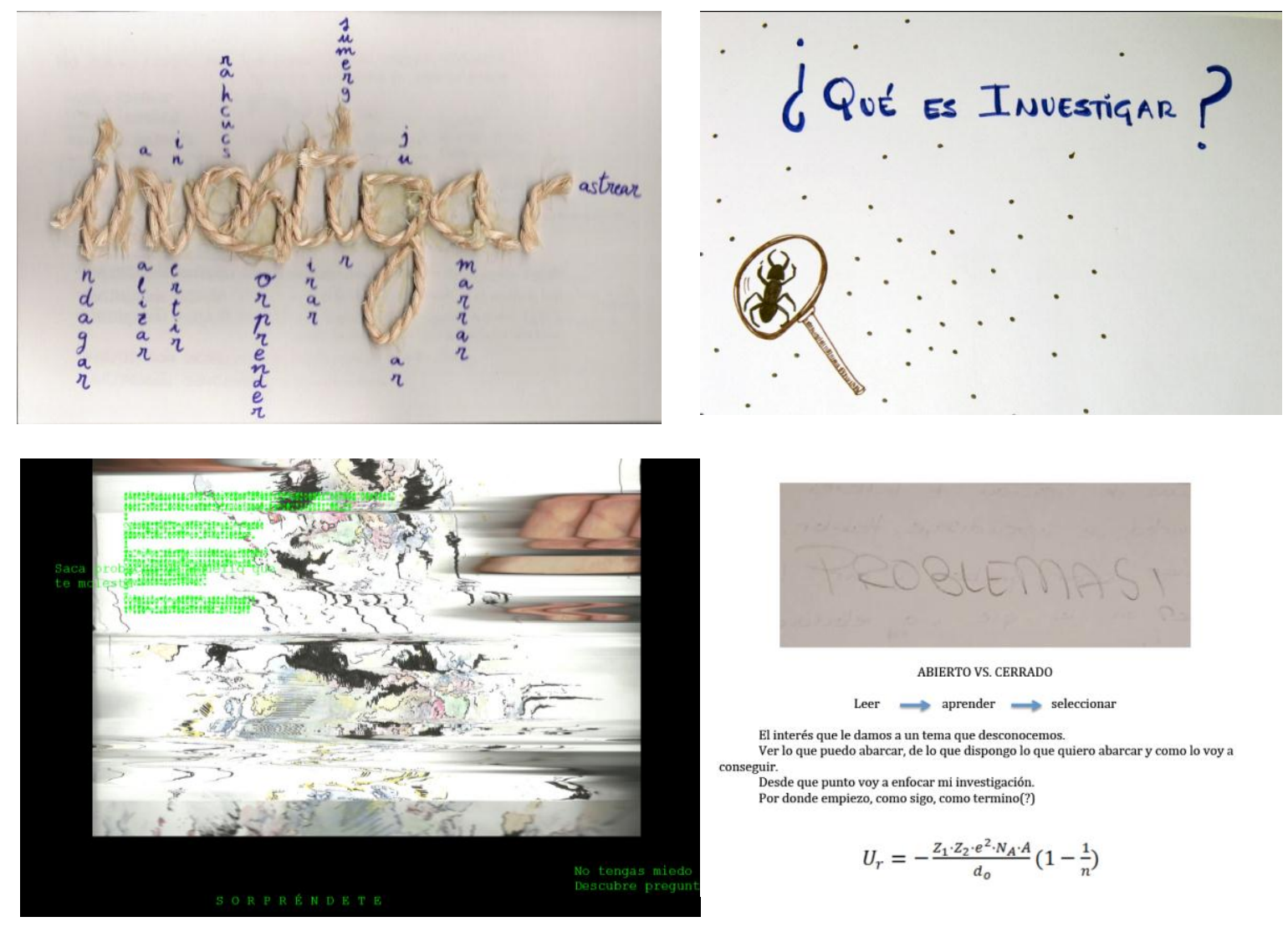

Miriam S., Fanfa, Pablo, Leire.

\section{Mi metodología}

Indagas, investigas. ¿Cuál es tu forma de hacerlo? ¿Mantiene alguna relación con alguna metodología de investigación que conozcas? Dale forma (haz un facto ${ }^{16}$ ).
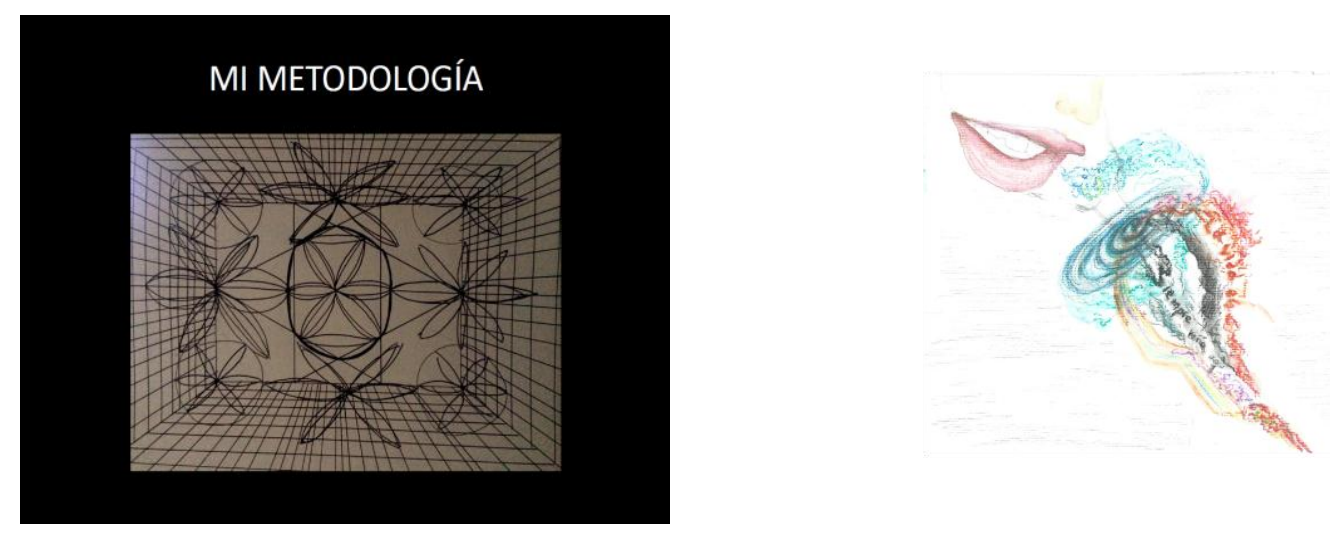

${ }^{16}$ Se refiere a la creación de carácter artístico que representen un concepto. Dicha creación ha de ser percibida a través de los sentidos. 

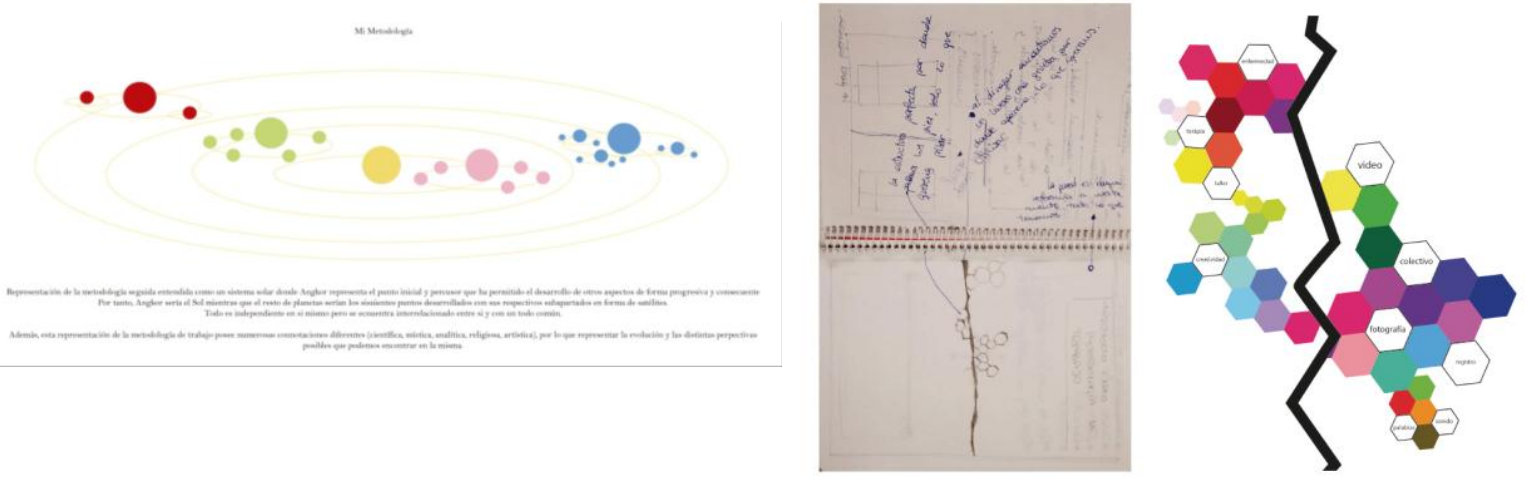

Natalia, Adriana, Beatriz, Leire.

3. Surgimiento del Test-indagación en el tránsito del aprendizaje docente (labor docente)

De los tres años que llevo impartiendo clase en el área de proyectos, el primero supuso la toma de contacto con las competencias que el grado exige que adquieran los estudiantes gracias a una formación interdisciplinar y transversal (técnico-práctica y teórica). Desde el inicio, trate de configurar un contenido que se situase en el paradigma de investigación actual en las Bellas Artes desde la práctica (en fase de generación) y, a la vez, ayudase a los estudiantes a conocer el ámbito de la investigación académica universitaria desde nuestra área, desde nuestras gafas de artistas-investigadores.

Aquel primer año, 2012-2013, elaboré materiales bajo títulos como: ¿Dónde está la inspiración?; Metodologías de investigación; Idea, concepto, contexto, encuadre y posicionamiento; Investigación-obra; etc. 


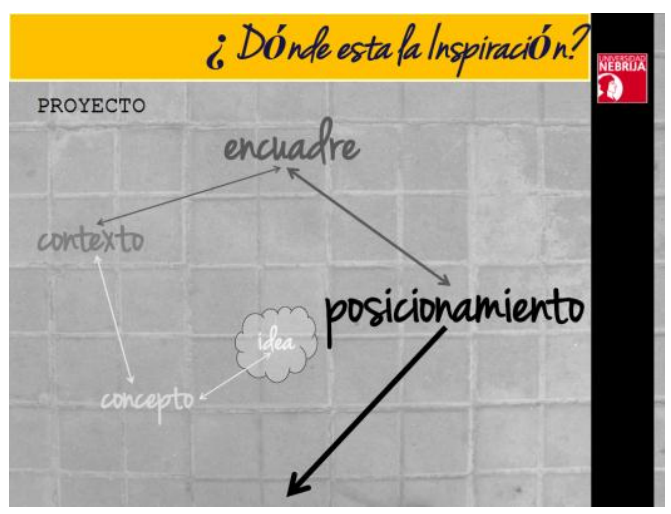

Fig2. Diapositiva de la presentación “¿Dónde está la inspiración?”. Asignatura: Creatividad y Proyectos. Grado en Bellas Artes.

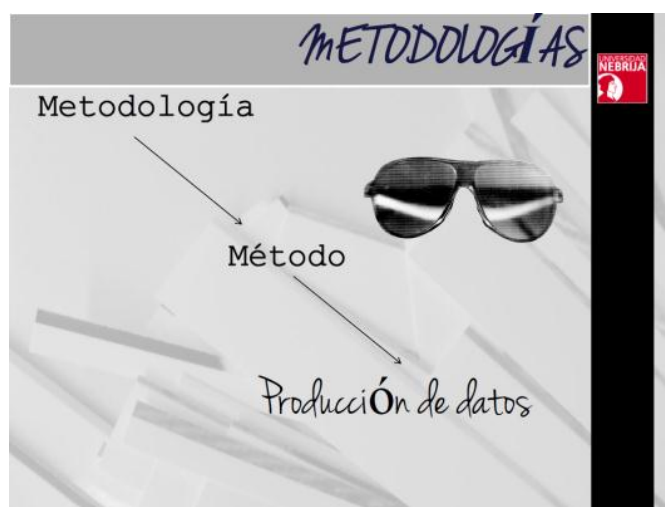

Fig3. Diapositiva de la presentación "Metodologías". Asignatura: Creatividad y Proyectos. Grado en Bellas Artes.

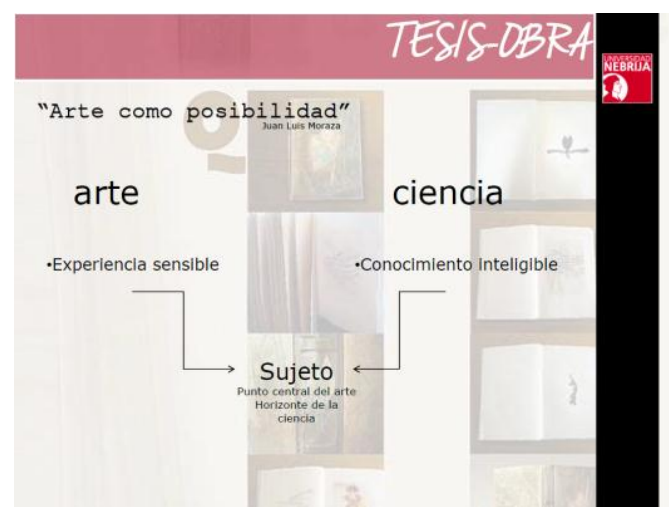

Fig4. Diapositiva de la presentación "Tesis (investigación)- Obra”. Asignatura: Creatividad y Proyectos. Grado en Bellas Artes. 
Tras la experiencia con aquel grupo, vi conveniente seguir utilizando este material para posteriores años aunque ajustando ligeras modificaciones.

El año siguiente, 2013-2014, volví a exponer el material citado anteriormente, al que añadí la elaboración de nuevos materiales titulados: Dinámicas creativas; Competencias. Esto fue debido a que advertí que el año anterior la teoría había copado demasiado las sesiones, mermando los espacios de taller en el aula. Por lo que, a estas dos nuevas presentaciones, sume el lanzamiento de diversas propuestas prácticas que iban ligadas a cada presentación teóricoreflexiva realizada.

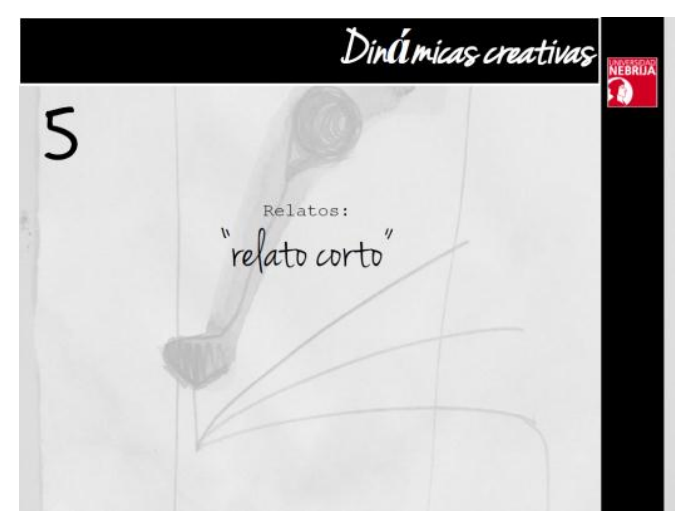

Fig5. Diapositiva de la presentación "Dinámicas creativas". Asignatura:

Creatividad y Proyectos. Grado en Bellas Artes.

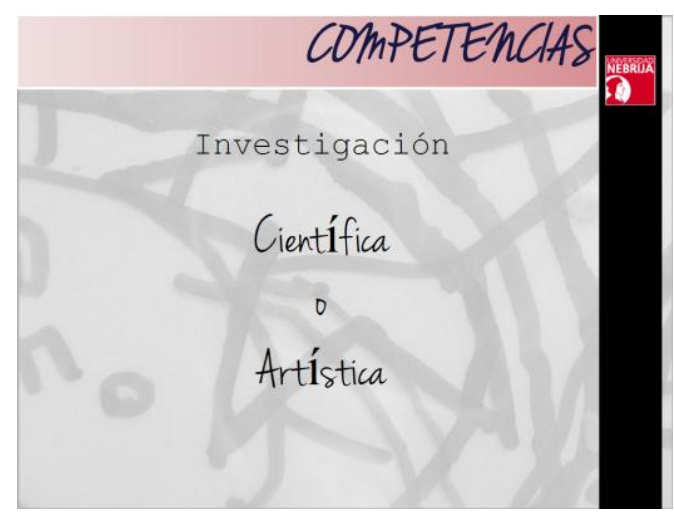

Fig6. Diapositiva de la presentación "Competencias". Asignatura: Creatividad y Proyectos. Grado en Bellas Artes. 
Según fue avanzando el curso llegó la necesidad de dar nombre y marco a estas propuestas y fue en una explicación en el aula cuando surgió el título de Test-indagación:

"Estos ejercicios los podéis ir haciendo poco a poco. Yo os los iré lanzando tras cada presentación y, en la segunda parte de cada sesión, dejaremos tiempo en clase para ir trabajando cada uno de ellos. Tomarlo como cuando hacemos un test, puedes dar respuesta a las preguntas una detrás de otra o saltar de una a otra según te vayas sintiendo seguro a la hora de contestar. Al final de la asignatura pondremos un día para que cada uno presente su Test-indagación, por decirlo de algún modo, mostrando paulatinamente y de manera libre (creativamente hablando), la solución que ha dado a cada una de las propuestas que os he ido haciendo. (Fragmento realizado a partir del recuerdo albergado en la memoria de la autora, que trata de plantear como se produjo el instante en que surgió la unión de vocablos test e indagación que le dieron nombre al método". Abril 2014).

Así surge el método, que entonces fue definido como:

"Oferta de propuestas que ayuden a dar sentido y forma al elemento contenedor del proceso indagador. Tejido de experiencias y resiliencias ${ }^{17}$ moderadas que presenten la investigación desde una actitud/posición indagadora."

Al finalizar ese año, una vez que la asignatura había finalizado y cerrado actas, lance a los estudiantes una última propuesta. Les pedí su colaboración para que me contestasen una serie de preguntas que me ayudarían a valorar el material utilizado dentro de la asignatura, con el ánimo de seguir evolucionándolo. A continuación expongo las preguntas realizadas y la selección de algunas de las respuestas dadas:

\footnotetext{
${ }^{17}$ En este contexto, se refiere a la capacidad que desarrolla el estudiante a la hora de avanzar en el proceso de indagación elaborando una propuesta del test, una tras otra (en el orden que él/ella decida) sorteando inseguridades, superando bloqueos, tomando decisiones, etc., donde cada solución alcanzada supone la evidencia que marca cada paso dado en el tránsito de indagación artística.
} 
¿Qué te han parecido los contenidos de los temas (presentaciones) vistos en el aula?

"La asignatura en todos los aspectos me ha parecido NECESARIA. La forma en la que nos la has dado me ha parecido la más idónea. Lo mejor ha sido ir haciendo el test indagación por actividades, y no solo mandado de una vez. También el hecho de que las presentaciones no fuesen teoría que estudiar sino herramientas para estructurarnos el trabajo". (Leire)

"Me han parecido muy interesantes, aunque algunos eran complejos de aprehender finalmente todos estaban relacionados y servían para comprender mejor la asignatura y su intención". (Ana)

\section{¿Los consideras útiles, o no?}

"Mucho, los definiría como un..."Sigue el camino de baldosas amarillas". Por un lado, se han reforzado nuestros conocimientos sobre el proceso creativo, nociones básicas sobre investigación, tipos... un poco de todo, pero lo más importante es que entre la espesura de los miedos y de lo desconocido, nos ha ayudado a entornar los ojos y descubrir el sendero a seguir". (Elena)

"Sí. Es más, pienso que estos contenidos deberían haberse dado al comienzo de la carrera y nos habrían sido muy útiles para conocer varias metodologías de trabajo”. (Margarita)

¿Define tu proceso de maduración como artistainvestigador a lo largo de esta asignatura?

He pasado de lo inconsciente a lo consciente y eso...que decir... jno tiene precio! (Elena) 


\section{Evalúa la herramienta de test-indagación ¿Para qué crees que te ha servido?}

Para poner mis ideas un poquito más ordenadas. Para darme cuenta de lo que no quiero hacer, y como lo que sí, influye en todos los aspecto de mi investigación, práctica y teórica. Creo que cada paso nos adelantaba una pequeña porción de lo que iba a ser el TFG, o bien ayudarnos a saber cómo enfocarlo. (Leire)

Me identifico con los niños que simplemente se lo pasan bien en clase y no saben que están aprendiendo. Echaba de menos algo así. (Elena)

Sé que podría haberle sacado más partido, haberla enfocado de otra manera más creativa y haberme dejado llevar...todos tenemos momentos, y hay cosas que no se pueden forzar.

Creo que me ha servido para reflexionar sobre que me interesa, y por qué, para conocerme más a través de lo que produzco o las obras o los artistas que me llaman la atención. El test está bien porque un indice común suele estar más acotado, sin embargo este test te da la oportunidad de salirte de esas cotas y esta posibilidad de creatividad está más acorde con nuestra carrera. (Margarita)

[...] Poco a poco todo ha ido tomando consistencia y color al introducir la "veracidad" de lo que investigas en algo subjetivo como es el arte. Personalmente me ha ayudado mucho a no dispersarme, a no abarcar proyectos que no parten de tu relación con el entorno, o que no tienes en cuenta el papel del "Otro". Por lo tanto me ha servido mucho a nivel personal a la hora de elaborar proyectos y mucha más soltura y confianza. Además como artista investigador me veo más capaz de llevar a cabo ideas de manera rigurosa y que encajen en el contexto en el que vivo. (Ana)

Una vez escuchadas las valoraciones de los estudiantes, en reunión de departamento se determinó que los contenidos de mi asignatura debían enmarcarse en un nivel inferior (pasar de $4^{\circ}$ a $3^{\circ}$ ), para que los estudiantes tuviesen un años más para poner en práctica los contenidos y asimilar lo aprendido. 
En relación al año anterior, los materiales fueron nuevamente revisados, surgiendo ligeras modificaciones y ampliaciones al elaborar nuevas presentaciones para este curso como: Aspectos básicos de investigación; Cuaderno.

Para este año académico, 2014-2015, determiné que las voces de los estudiantes no fuesen una aportación no puntuable para su evaluación de la asignatura. Así, como parte del examen final, les propuse realizar un texto con una extensión máxima de dos folios, en el que ser capaces de expresar su proceso, es decir, el punto en el que empezaron en la asignatura y qué aspectos, tratados en el aula, habían contribuido a su evolución en cuanto al trabajo de investigación que emprendieron al inicio e incluso en cuanto a su maduración como artistas.

El hecho de que esta "auto-evaluación" fuese a su vez valorada para la nota final, posee su sentido en que el broche perfecto para el Testindagación (como contenedor, aglutinador del proceso), podía ser el ejercicio auto-reflexivo que cada estudiante realizase en base a su propio trabajo, apoyando así la adquisición de una de las competencias del grado que, bajo mi criterio, tiene mayor relevancia para el futuro profesional (y vida en general) de los estudiantes: Capacidad de (auto) reflexión analítica y (auto) crítica. (Competencia 25. Ficha de Área de Proyectos).

De este modo voy a exponer a continuación algunos extractos de los textos que los estudiantes elaboraron para tal fin:

[...] Además, el Test-indagación no solo te abre las puertas a una investigación, que te permite descartar ciertos caminos o escoger otros; sino que al mismo tiempo utiliza diversas herramientas artísticas, que proporcionan diferentes ideas para la materialización de la obra final, por ejemplo, la narración, las palabras, los sonidos, lo espacial, lo visual, etc. (Miriam)

Lo mágico de este proceso, lo que ha hecho que esto realmente me sirva para andar y correr caminos, han sido los rastros y las pistas que han supuesto para mi travesia, esas tareas y ejercicios que se nos "invitaba" a hacer. Estando perdido, uno no sabe hacia dónde dar el primer paso, y la invitación a probar a hacer un relato evocador, o todas esas 
propuestas, sin duda significa hacer camino. Hacer camino que sorprende, al comprobar que no acabas donde imaginabas terminar. Prestar atención a los detalles que te vas encontrando, enriquece $y$ despierta ideas y sensaciones, que no cabia esperar encontrar. (Pablo)

La clase impartida sobre metodologías me ayudó a saber dónde buscar y como legitimar mi búsqueda, al igual que la elaboración del ensayo, que me obligó a defender mi postura a partir de otro punto de vista de un tema totalmente distinto. Esto me permitió ver que podía apoyarme en cualquier texto para defender mi investigación, siempre y cuando tuviese lógica. (Adriana)

En esta segunda parte de la asignatura bicimos un análisis más profundo de nuestro interés. El collage y la metodología fueron unas herramientas para mostrar nuestra forma de trabajar en todos los ejercicios [...] El Otro: nunca be hecho una exposición asi que, no sabia hacia quien podría ir dirigido este proyecto, ni el interés que podría tener. No me di cuenta de todo esto, hasta que bice los dibujos de dar forma a mi proyecto. (Irene)

\section{Auto-reflexión}

Gracias a todas estas voces que han estimulado profundas reflexiones, he podido alcanzar una serie de planteamientos que ayudan a dar más cuerpo y sentido a este método de indagación artística en su revisión y modulación año tras año. A través de la elaboración del Test-indagación llega un momento en el que los estudiantes advierten que en su proceso pueden llegar a donde no imaginaban o directamente no llegar. En ese momento es cuando aparentemente se hace tangible la asimilación de las siguientes cuestiones:

- Apertura hacia la actitud reflexiva, relacional, circunstancial, etc. del artista investigador valorando gracias a ella cada parte del proceso como parte o peldaño del mismo. Este método trabaja sobre el aprendizaje significativo gracias al reajuste, reconstrucción y asimilación de lo nuevo sobre lo ya conocido. 
- Estas propuestas ayudan a los estudiantes a comprender a través de la práctica artística, la construcción de una investigación dentro del marco académico universitario. Pues, sobre los aspectos básicos de una investigación, los estudiantes trabajan desde la naturaleza propia de su práctica modulando, destilando y devolviendo completados los requerimientos básicos de todo estudio de investigación. Gracias al carácter resignificativo del arte, damos forma a lo, hasta ahora, informe para que transcienda a su creador en la necesidad de componer la naturaleza de la propia investigación artística. Este hecho se hace posible a través de un proceso indagador no lineal que permite al artista-investigador caminar sobre sus pasos lo necesario (sobre su red), para ir reflexionando a cerca de sus planteamientos y problemas de investigación en base a sus creaciones (evidencias).

- Gracias a la elaboración del Test-indagación, afloran pequeños submundos desde el interés inicial sobre el que comenzaron el proyecto, cuya estampa volumétrica (metafóricamente hablando) les permite valorar y acercarse al proyecto desde diferentes perspectivas, susceptibles de acabar siendo parte o no, de la investigación en curso y/o de posteriores estudios.

- Paso a paso, recorrido a recorrido, para los estudiantes llega un momento en que paran y advierten que ya han alcanzado el claro sobre el que poder concluir el trabajo, a través de la generación de una obra artística que aglutine el material elaborado de manera implícita, o erguir, estructurar y explicitar el proceso de indagación artística como obra de arte en sí misma.

- Del mismo modo, paso a paso, recorrido a recorrido, como docente, posiblemente este método siga evolucionando extrayéndose a través del trabajo colaborativo con los estudiantes, diferentes versiones de él. O quizá llegue el momento en que alcancemos otro método de enseñanza para el hacer-investigador en Bellas Artes que responda a otras necesidades nuevas y/o distintas de las que hoy en día tenemos en nuestro campo, en actual generación y resignificación. 


\section{Referencias bibliográficas}

- AA.VV. (1998) La Investigación en Bellas Artes: Tres Aproximaciones a un Debate. Grupo Editorial Universitario. Granada.

- AA.VV. (2008) El medio audiovisual como herramienta de investigación Social. Serie: Dinámicas interculturales. Vol. 12.Ed: Cidob, Editions. Barcelona.

- Borgdorff, Henk (2005) El debate sobre la Investigación en las artes. Amasterdam School of Arts.

- Real Academia Española. (2001). Diccionario de la lengua española (22.a ed.). Consultado en http://www.rae.es/rae.html

- Stewart, Ian. (2008) Belleza y Verdad. Ed. Crítica. Barcelona.

\section{Referencias audio-visuales}

- Fuentes Cid, Sara (2008). El proceso recursivo. Modelos y escalas en la representación escultórica. Facultad de Bellas Artes. Universidad de Vigo. Cortizas Varela, Olalla (2010). Trabajo de Investigación: Cartografía volumétrica para la experiencia cotidiana del arte. Facultad de Bellas Artes. Universidad de Vigo. Disponible en: http://vimeo.com/85107138 - Abad Molina, J. (2009). Iniciativas de educación artística a través del Arte Contemporáneo para la Escuela Infantil. Facultad de Bellas Artes.

Universidad Complutense de Madrid. Disponible en: http://educacionartisticaenespania.blogspot.com.es/2010/12/narraci ones-y-espacios-para-el-arte.html - Artista-investigador Juan Luis Moraza. Disponible en: http://tv.uvigo.es/video/index?mm id $=1678$ 



\section{Autores}

\section{Coordinadores}

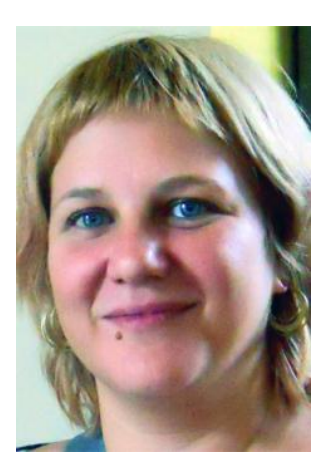

Raquel Sardá Sánchez

Licenciada en Bellas Artes por la Universidad Complutense de Madrid. Doctora en Ciencias de la Comunicación por la Universidad Rey Juan Carlos y Premio Extraordinario de Doctorado. Especializada en estudios sobre Patrimonio Cultural, Museos y Nuevas Tecnologías. Coordinadora del Grado en Bellas Artes de la Universidad Rey Juan Carlos. Docente en el Departamento de Ciencias de la Educación, el Lenguaje, la Cultura y las Artes de la Universidad Rey Juan Carlos de Madrid. Ha impartido docencia en la Comunidad de Madrid, en la Escuela Superior de Arquitectura (U.P.M.), la Universidad de Málaga y en el Instituto Superior de Arte Iart. Ha desarrollado su actividad profesional como Jefa de Proyecto y Consultora en Telefónica Soluciones, coordinando y realizando proyectos multimedia e innovación relacionados con nuestro Patrimonio Cultural y Artístico. Ha realizado exposiciones de escultura, grabado y fotografía, obteniendo diversos premios y becas.

raquel.sarda@urjc.es

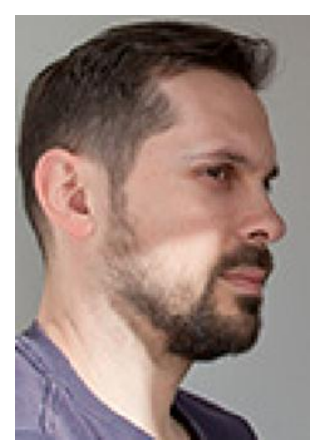

\section{Ricardo Roncero Palomar}

Doctor en Ciencias de la comunicación. Coordinador Erasmus/Mundi en Comunicación Audiovisual. Universidad Rey Juan Carlos, Madrid (www.urjc.es). Profesor en Grado de Comunicación Audiovisual. Universidad Rey Juan Carlos, Madrid. Profesor en Master de Periodismo cultural y nuevas tendencias.

Universidad Rey Juan Carlos, Madrid. Director de proyectos en laboratorio de fotografía analógico. Centro cultural Fundación La Casa Encendida, Madrid. ricardo.roncero@,urjc.es 


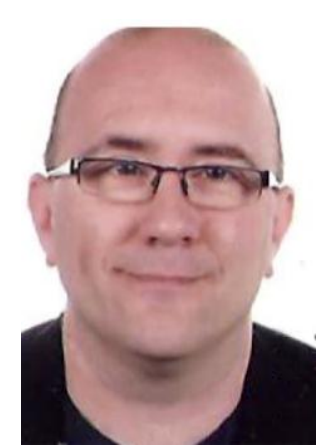

\section{Rafael Gómez Alonso}

Licenciado en Ciencias de la Imagen en 1994. Doctor en Ciencias de la Información en 1999. Profesor Titular del área de Comunicación Audiovisual y Publicidad desde 2006. Actualmente ejerce la docencia en la Universidad Rey Juan Carlos donde imparte las asignaturas de Narrativa Audiovisual, Evolución de la Artes Escénicas y Visuales, Proceso Audiovisual, y el curso de posgrado Estética y Cultura Audiovisual Contemporánea.

Miembro del GRUPO COMPLUTENSE DE ESTUDIOS CINEMATOGRÁFICOS (ESCINE) y del Proyecto I+D "La imagen de marca del cine español" (CSO2011-24622)

Autor de los libros Cultura audiovisual. Itinerarios y rupturas (Laberinto Comunicación, 2007), Análisis de la imagen. Estética audiovisual (Laberinto Comunicación, 2001), Arqueología de la imagen fílmica: De los orígenes al nacimiento de la fotografía (Archiviana, 2002), coautor de los libros Fotoperiodismo y Edición (Universitas, 2003) Historia del cine (Fragua, 2010), El Madrid de Felipe IV. Análisis fílmico y literario de Crónica del Rey Pasmado (Comunidad de Madrid, 1997, premiado por la Consejería de Educación y Cultura). Actualmente tiene en prensa el libro Teorías de la Cultura Audiovisual y de los Nuevos Medios (Síntesis, 2015).

Ha escrito diversos artículos para revistas culturales relacionadas con el mundo de los medios de comunicación (Secuencias, Área Abierta, Telos, Enlaces, Icono14, Historia 16...) y ha participado y colaborado en diversas investigaciones tanto para el ámbito universitario como para empresas del sector audiovisual.

rafael.gomez@urjc.es 


\section{Colaboradores}

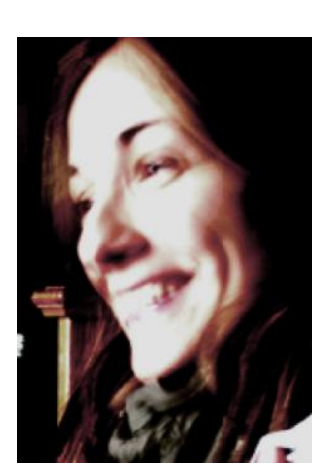

\section{Rosa Jiménez Morales}

Doctora en Comunicación por la Universidad Rey Juan Carlos y tiene un master en Estudios Literarios y Literatura Comparada.

Es profesora en la Escuela Universitaria Tai en el área de cinematografía, y en la Universidad Internacional de la Rioja. Imparte asignaturas relacionadas con la Estética y la Cultura Visual.

Ha realizado estancias de investigación en Goldmisth College (University of London) y Ruskin College (Oxford University). Ha publicado diferentes artículos relacionados con la Cultura Visual y los Estudios Culturales.

En la actualidad compagina la docencia con la fotografía. jimenezm.rosa@gmail.com

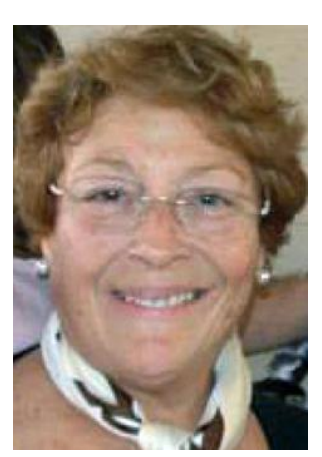

\section{Celia Balbina Fernández Consuegra}

Doctora Cum Laude. Premio de Investigación 2013. Especialista en Estética y Teoría de las Artes y Especialista en Diseño de la Comunicación y en Tecnologías Escénicas. Destacada investigadora de la Universidad Rey Juan Carlos, es profesora investigadora de esta universidad. La Actividad Académica que realiza está basada en Clases de Composición, Percepción Visual y Color; clases de Fotografía Básica; Clases de Ilustración como Ensayo Visual y Clases de Estudios de Performance en las carreras Artes Visuales y Danza y Pedagogía de las Artes Visuales y Danza del Instituto Universitario de la Danza "Alicia Alonso", Universidad Rey Juan Carlos. Clases magistrales de Adobe PhotoShop, Lenguajes Escénicos y Composición, Percepción Visual y Color en el Master de Artes Escénicas del Instituto Universitario de la Danza "Alicia Alonso", Universidad Rey Juan Carlos. También imparte la asignatura Estudios de Performance en el Master de Artes Escénicas.

celia.fernandez@urjic.es 
Paralelamente a las actividades académicas, realiza una labor de creación artística dentro del campo de las Artes Visuales desde 1987; esta obra se ha expuesto en España, Italia y Estados Unidos.

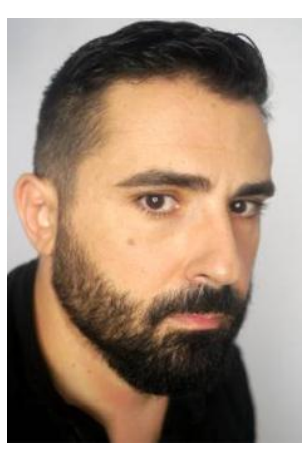

\section{Francisco José Gómez Díaz}

Doctorando en Comunicación Audiovisual (UCM), Máster en Cine, TV y Medios interactivos (URJC) y Licenciado en Publicidad y Relaciones Públicas (UCM). Miembro del grupo de investigación Museum $\mathrm{I}+\mathrm{D}+\mathrm{C}$ (Laboratorio de Cultura Digital y Museografía Hipermedia) de la Universidad Complutense de Madrid, en el que participa de forma activa tanto en la investigación como en la creación de contenidos. A parte del desarrollo de producciones propias independientes en soporte de vídeo, mantiene colaboraciones con diferentes artistas (como Eva Lootz) y con otras universidades como la URJC, además de trabajar como experto en comunicación, especializado en redes sociales y tecnologías de la información.

frango04@ucm.es

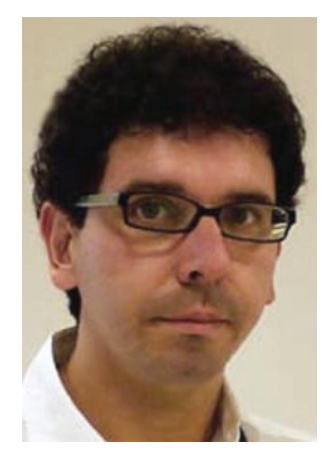

\section{José Luis Crespo Fajardo}

Doctorado (PhD) en Bellas Artes por la Universidad de Sevilla. Ha publicado numerosas obras monográficas y ha coordinado una decena de libros colectivos. Ha sido conferenciante en una veintena de congresos internacionales y ha hecho exposiciones individuales en España, Portugal, Inglaterra y Ecuador. Dirige la revista Arte y Sociedad. Está en posesión de la Acreditación Nacional como profesor Ayudante Doctor por la ANECA (Agencia Nacional de Evaluación de la Calidad y Acreditación). Ha sido profesor de la Facultad de Bellas Artes de Sevilla y ha realizado estancias posdoctorales en las Universidades de Lisboa y Oxford. Durante los últimos dos años ha sido investigador del Proyecto Prometeo (SENESCYT) en la Universidad de Cuenca (Ecuador) luis.crespo@,ucuenca.edu.ec 


\section{Laura de Miguel Álvarez}

Doctora en Bellas Artes (UCM, 2010)

Profesora universitaria en área de proyectos y diseño. Ha realizado y proyectado diversas exposiciones, individuales y colectivas, como artista multidisciplinar y comisaria. Su interés y hacer investigador se mueven en el desarrollo de trabajos de carácter artístico que versan sobre la búsqueda de diferentes formas de narrar la experiencia, explorando a través de métodos y estructuras discursivas la manera de visibilizar los procesos artístico-creativos inherentes al hecho creador.

Desde el año 2007 colabora con diversas entidades sin ánimo de lucro en una línea de investigación que valora el papel del arte en la construcción y representación social. Cofundadora de la asociación LUNZO: por la visibilidad de las personas. ( $\mathrm{n}^{\circ}$ registro: 31229$)$.

laura@,lauradm.com - lmiguela@,nebrija.es 